\title{
In vitro propagation and germplasm conservation of wild orchids from South America
}

Natalia Raquel Dolce* ${ }^{1}$, Ricardo Daniel Medina ${ }^{1}$, Graciela Terada ${ }^{1}$, María Teresa GonzálezArnao $^{2}$, Eduardo Alberto Flachsland ${ }^{1}$

${ }^{1}$ Instituto de Botánica del Nordeste (IBONE), Universidad Nacional del Nordeste (UNNE) - Consejo Nacional de Investigaciones Científicas y Técnicas (CONICET). Facultad de Ciencias Agrarias, UNNE. Sargento Cabral No 2131, C.C. 209, 3400 Corrientes, Argentina. E-mail:

ndolce@agr.unne.edu.ar,nrdolce@gmail.com

${ }^{2}$ Facultad de Ciencias Químicas, Universidad Veracruzana, Prol. Oriente 6, No. 1009, C.P. 94340, Orizaba, Veracruz, México.

\begin{abstract}
Orchids are an important part of plant biodiversity on the planet due to their high variability among species and their habitats. South America presents more than thirty percent of all known orchid species, being Colombia, Ecuador, Brazil, Peru, and Bolivia between the richest countries in the world in terms of orchid biodiversity. Nevertheless, concerning to the orchid conservation status, in Colombia precisely orchids occupy the unlucky first place as the plant family with the highest number of threatened species. Similar situation is happening in the rest of the South American countries. The two main threats to orchid survival are both anthropogenic: the first one is deforestation, and the second largest threat to orchids is collection from the wild. One desirable action to safeguard these endangered species is to develop procedures that make possible their massive propagation, which should provide material for the eco-rehabilitation of specimens into their natural habitats, the exchange with other entities, the supply to orchid merchants for avoid extractions of nature, and the availability of material for future research. Likewise, the development of systems that allow the ex situ conservation of orchid germplasm is imperative. This chapter reviews the progresses of different in vitro approaches for orchid propagation and germplasm conservation, safeguarding the genetic biodiversity of these species. Several study cases are presented and described to exemplify the protocols developed in the Botanical Institute of Northeast (UNNE-CONICET) for propagating and long-term storing the germplasm of wild orchids from Argentina (Cattleya lundii, Cohniella cepula, Cohniella jonesiana, Gomesa bifolia, Aa achalensis, Cyrtopodium brandonianum, Cyrtopodium hatschbachii, Habenaria bractescens). Moreover, it has been attempted to put together most of the available literature on in vitro propagation and germplasm conservation for South American orchids using different explants and procedures. There are researches of good scientific quality that even cover critical insights into the physiology and factors affecting growth and development as well as storage of several orchid materials. Anyway, studies are still necessary to cover a mayor number of South American species as well as the use of selected material (clonal) for both propagation and conservation approaches.
\end{abstract}

Keywords Orchid biodiversity - Seed germination - Somatic embryogenesis - Shoot organogenesis $\cdot$ Plant regeneration $\cdot$ Seeds storage $\cdot$ Pollen storage $\cdot$ Cryopreservation 


\section{INTRODUCTION}

South America is a megadiverse continent in terms of orchid species. Just between Colombia and Ecuador, the two richest countries in the world in orchids, add 9,000 species (which represent the thirty percent of all known orchid species). However, in both countries the number of orchid species threatened with extinction may well add 3,000 species, a figure quite worrying when we consider that the main cause of this extinction is deforestation of the Andean forests. Precisely the forests of these mountains provide most of the water resources for the large cities and their agriculture and industries (Orejuela Gartner 2010).

Orchids fascinate people more than any other plants do. They were and are the reason for journeys to remote corners of the planet in order to discover new species (Vásquez et al. 2003). Even more, there is a rich history between orchids and people in many cultures across the world. Orchids have had many practical uses, but they have also had a unique allure based on their aesthetic appeal. The first known documentation of the appreciation and use of orchids dates back to Confucius (551-479 B.C.). Since then, these plants have been used as a source of food, medicines, ornamentals, flavoring (vanilla), teas, charms, aphrodisiacs, ingredients in magic, to promote or retard fertility, for clothing, art, poisons, narcotics, and religious ceremonies (Cuoco and Cronan 2009; Koopowitz 2001). Hence, the significance of orchids in human life cannot be subestimated.

Due to the high specificity for insect pollinators, minute seeds without endosperm and a unique life cycle requiring an association with specific mycorrhizal fungi during the early stages of development, orchids are vulnerable to minor biotic and abiotic changes (Popova et al. 2016). Thus, widespread degradation of ecosystems (for example as a result of an increased use of weed killers and artificial fertilizers, deforestation, and land clearance), has imperilled orchids in their natural habitats (Farrell and Fitzgerald 1989; Kandavel et al. 2004; Swarts and Dixon 2009; Wood 1989). Moreover, global warming is predicted to produce irreversible changes in orchid communities (Seaton et al. 2010).

Internationally, the importance of conserving orchids has been recognized since the 1970s when orchids were listed in CITES (Convention on International Trade in Endangered Species of Wild Fauna and Flora). While CITES originally focused on gathering data on the international trade of animals, the design shifted to include the preservation of both flora and fauna, partly in reaction to a perceived increase in the illicit trade of plants (Koopowitz 2001). At present, orchids figure prominently in the Red Data Book prepared by International Union of Conservation of Nature and Natural Resources (IUCN). In fact, the entire family is now listed under Appendix I or II of the Convention on International Trade in Endangered Species of Wild Fauna and Flora (CITES; http://www.cites.org). As palliative action, governments from many countries have established Biosphere Reserves, National Parks and Sanctuaries in the orchid rich regions besides banning the export of orchids collected in wild. Unfortunately, in situ conservation is not always a viable option because of reasons like fragmented habitats, absence of pollinators due to indiscriminate use of pesticides or other modifications of the biome etc (Chugh et al. 2009).

Despite having a large number of orchid species and diversified agroclimatic conditions, the orchid industry has not been developed in South America although it has great potential. Hence, an efficient strategy needs to be designed not only to save these beautiful members of the plant kingdom but also to harness the economic potential by scientific and judicious management. This requires a complex integration of preserving natural habitats (in situ 
conservation), developing and applying ex situ conservation methodologies, being also necessary to standardize commercial-scale micropropagation techniques for production of quality planting material of important, rare, endangered, threatened as well as exotic hybrid orchids. Moreover, deeper insights of orchid biology, evolution and ecology are needed, as well as a better understanding of the orchid trade and horticultural practices (Popova et al. 2016).

The aim of this chapter is to review and provide information about the available methods for the in vitro propagation and germplasm conservation of wild orchids from South America. Several study cases are presenting to illustrate the development of these biotechnological approaches in the Botanical Institute of Northeast (IBONE), UNNE-CONICET (Argentina).

\section{Biodiversity of South American Orchids}

Orchids are an important part of plant biodiversity on the planet due to their high variability among species and their habitats. The highest diversity of orchid species has been found in the Andes of Colombia and Ecuador, tropical rainforests of Borneo, Sumatra, New Guinea and Madagascar (Cribb et al. 2003; Swarts and Dixon 2009). Every year botanists discover over one hundred new orchid species (e.g. Carnevali et al. 2014; Kolanowska 2015; NogueraSavelli et al. 2008; Vale et al. 2014). Clearly, our knowledge of orchid genetic diversity is fairly incomplete, and there is the prospect that many orchid species may be lost before their discovery.

Concerning to South America, it presents more than thirty percent of all known orchid species. Colombia and Ecuador are the richest countries in the world in terms of orchid biodiversity. In Colombia have been cited between 3,500 and 4,270 species, of which 1,572 (37\%) are endemic (Jørgensen et al. 2011; Ministerio de Ambiente y Desarrollo Sostenible y Universidad Nacional de Colombia 2015), while in Ecuador have been identified 4,032 orchid species, of which 1,714 (43\%) are endemic (Cerna et al. 2016). Likewise, Brazil (with 2,548 recorded orchid species; Zappi et al. 2015) and Peru (with 2,020-3,500 orchid species; Perú Ministerio del Ambiente 2015; Roque and León 2006) are known among the countries with more orchid megadiversity in the world. Concerning to Bolivia, until very recent times it was rather underestimated and neglected with regard to orchid diversity; however, according to current estimates (considering the currently known species number, the discovery rates and the dimensions of the unsampled areas) there are about 2,000-3,000 orchid species in the country (Vásquez et al. 2003). Thus, Bolivia's orchid diversity could become comparable to more northern Andean countries like Peru and Ecuador where much more effort has been spent on orchid inventory. Similarly, in Venezuela the Orchidaceae is one of the best represented plant families with 1,506 species. Detailed floristics and inventories, however, are needed for different unexplored and underexplored areas of the national parks of Venezuela (Noguera-Savelli et al. 2015). On the other hand, for countries of the Southern Cone of South America (Argentina, Chile, Paraguay, Uruguay, and Southern Brazil) have been identified 1,042 orchid species, of which 294 are endemic (Zuloaga and Belgrano 2015); while 760 species have been cited for Guyana, Suriname, and French Guiana (Funk et al. 2007) and approximately 200 species have been recorded for Trinidad and Tobago (Kenny 2008).

Regarding to the orchid conservation status, in Colombia orchids occupy the unlucky first place as the plant family with the highest number of threatened species (Calderón-Sáenz 
2007). Colombia contains two recognized biodiversity hotspots, The Northern Andes, and the Tumbes-Chocó-Magdalena (Myers et al. 2000), of which the Chocó region on the Pacific coast harbors unparalleled plant biodiversity (Gentry 1986). All of these habitats are under considerable threat of deforestation, due to the continued direct impact of habitat conversion for agriculture and mining (both legal and illegal), as well as the increasingly common forest fires (González et al. 2011). In 2014, the Colombian national deforestation rate registered an increase of $14 \%$ compared with the previous year, with a total of 140,356 Ha lost. Only $4 \%$ of the original cover of tropical dry forest remains in Colombia, and most deforestation are occurring in the Amazon and Andean regions (Cavelier and Etter 1995; Fandiño and Wyngaarden 2005; Pizano and García 2014). In the Chocó biogeographic region along the Pacific littoral, which still retains a high proportion of natural forest habitat, the annual average of deforested area moved from 2,874 ha per year in 2012-2013 to 24,025 ha per year in 2015-2016 (IDEAM 2015). In addition to habitat degradation, orchids, being of commercial interest, are subject to the pressure of collection from wild populations (Calderón-Sáenz 2007). Something similar is happening in Ecuador, the second megadiverse country in orchids, which has a great variety of climatic regions that potentiate biodiversity. In Ecuador, the incredible orchid array is also being threatened by land-clearing practices and illicit collection. This situation is the result of (a) insufficient resources to address conservation needs, (b) weak funding and inter-agency coordination at the government level, (c) poor historic coordination among the large regional network of conservation groups, and (d) a disconnect between conservation agendas and local communities (Cuoco and Cronan 2009). Similarly, this situation is repeated in most of the South American countries.

Thus, the two main threats to orchid survival are both anthropogenic. The first threat is deforestation. Many species of orchids in their natural state require large areas of undisturbed forests to be reproductively successful (Dodson and Escobar 1993). Unfortunately, orchid habitat in most of South America has been destroyed to clear lands for cattle ranching, agriculture, and road building. Collection from the wild is the second largest threat to orchids (Dodson and Escobar 1993). Given the lack of regulation of wild orchid collection and the illicit nature of most collections, it is nearly impossible to determine the volume of orchids that are removed from forests every year (Cuoco and Cronan 2009).

One desirable action to safeguard these endangered species is to develop procedures that make possible their massive propagation, which should provide material for the reinsertion of specimens into their natural habitats, the exchange with other entities, the supply to orchid merchants for avoid extractions of nature, and the availability of material for future research. Likewise, the development of systems that allow the ex situ conservation of orchid germplasm is imperative. Ex situ conservation refers to the preservation of plant germplasm outside its natural habitat (Heywood and Iriondo 2003). This involves different methods, some of which are classified as dynamic, like botanic gardens and field genebanks, because both provide the opportunity of monitoring the evolutionary trajectory of samples during the storage. Other ex situ methods are classified as static, because they safeguard the genes outside of the evolutionary context (Shands 1991). They are considered safest, uninfluenced by the climate conditions, and more cost-effective than dynamic methods. Some alternatives for ex situ conservation are the seed banks and the storage of different plant materials in liquid nitrogen $\left(\mathrm{LN},-196^{\circ} \mathrm{C}\right)$. 


\section{In Vitro Propagation Approaches in Orchids}

\section{In vitro seed germination}

One of the most significant applications of biotechnology to orchid diversity conservation and sustainable use is in vitro germination (Popova et al. 2016). Orchid seeds (which are produced in large numbers in each capsule) are very small and lack food reserves (Heywood et al. 2007; Mitra 1971; Paudel et al. 2012). In nature, orchid seeds associate with specific mycorrhizal fungi (symbiotic germination) that induce germination and promote embryo growth, supplying the required nutrients to the embryo (Rasmussen et al. 2015; Valadares et al. 2012). Thus, propagating orchids through seeds may require the presence of specific fungi or specific culture media which can replace the nutrient supply given by such fungi (Otero Ospina and Bayman 2009).

Development of asymbiotic germination methods (i.e. without fungal inoculation) of orchid seeds took place following the formulation of Knudson B and C medium (Knudson 1922, 1946). Thereafter, other culture media with varied carbon sources have been tried for orchid germination such as Vacin and Went medium (VW; Vacin and Went 1949), Murashige and Skoog medium (MS; Murashige and Skoog 1962), Mitra medium (M; Mitra et al. 1976), Malmgren Modified Terrestrial Orchid Medium (MM; Malmgren 1996), banana culture medium (CMB; Barbery and Molares 2011), tomato culture medium (CMT; Barbery and Molares 2011), PDA medium (Potato Dextrose Agar), among others (Hossain et al. 2010; Paul et al. 2011; Pedroso-de-Moraes et al. 2012; Pedroza-Manrique and Mican-Gutiérrez 2006; Pereira et al. 2015; 2017; Piri et al. 2013; Roy et al. 2011; Wida Utami et al. 2017). These media can have different results depending on the orchid species, suggesting intrinsic differences in nutrient requirements for different species. It has also been suggested that particular species may have different limiting factors for germination and seedling early growth (Rasmussen et al. 2015). For example, mature seeds of some orchid species require several months of cold stratification before germination (Nikishina et al. 2007), and the whole process of embryo development to plantlet formation can take months to years, particularly for temperate species (Nikishina et al. 2001; Olivia and Arditti 1984). Likewise, mature seeds of Vanilla species require chemical scarification before culture for asymbiotic germination, since they have hard coats (Pedroso-de-Moraes et al. 2012). For such species, immature seeds that readily germinate after sowing are considered a primary material for the initiation of tissue cultures (Hirano et al. 2005a,b; Nikishina et al. 2007; Palama et al. 2010; RamírezMosqueda and Iglesias-Andreu 2015). However, based on an understanding of dry seed storage of other species, such immature seeds may not be optimal for long-term storage (Popova et al. 2016).

Asymbiotic germination can be more effective than symbiotic germination for several reasons: 1) it does not require the isolation and identification of the mycobiont of the target orchid species; 2) it allows for more controlled, aseptic conditions, resulting in less overall contamination (Abraham et al. 2012; Aggarwal and Zettler 2010; Johnson et al. 2007); 3) in symbiotic germination, the seeds inoculated with the mycorrhizic fungi can be completely covered with the fungal hyphae, making difficult the evaluation of germination and embryo development, sometimes requiring a change in the culture media, increasing the risk of contamination (Pereira et al. 2017). However, it is likely that further plant development and/or re-introduction of plants in the field could require fungal association to enhance survival 
(Otero Ospina and Bayman 2009; Pereira et al. 2015; Thakur and Dongarwar 2013). Anyway, both symbiotic and asymbiotic seed germination can be very helpful for conservation of rare or endangered species, since orchids produce large amount of seeds and high genetic variation is preserved, compared to cloning techniques.

During the last twenty years tissue culture techniques have been extensively used for rapid and large-scale propagation of several South American orchids by both asymbiotic and symbiotic seed germination (see Table 1).

\section{Clonal propagation using various explants}

In vitro propagation using seedlings is less desirable especially for horticultural uses due to the long juvenile period before flowering (Decruse et al. 2003). Moreover, as orchids are outbreeders, their propagation using seeds leads to the production of heterozygous plants. Hence, protocols providing regeneration from various vegetative parts of mature plants are essential.

In 1949, Rotor at Cornell University demonstrated that plantlets could be induced by aseptic culturing of the dormant buds on the basal nodes of Phalaenopsis inflorescence (Arditti and Krikorian 1996). Thereafter, Morel (1960) cultured shoot tips for obtaining virusfree Cymbidium clones in vitro. Many efforts have been made since then for rapid clonal propagation using somatic explants from several orchid species, including shoot tips (Geetha and Shetty 2000; Kalimuthu et al. 2006; Ket et al. 2004; Seeni and Latha 2000; Sharma and Tandon 1992; Sheela et al. 2004), inflorescence explants -shoot apex, flower stalk nodes, and floret tissues- (Chen and Chang 2000; Chen et al. 2002; Goh and Wong 1990; Intuwong and Sagawa 1973; Mitsukuri et al. 2009; Shimasaki and Uemoto 1991; Vendrame et al. 2007a), leaf explants (Goh and Tan 1979; Janarthanam and Seshadri 2008; Sharma and Vij 1997; Teng et al. 1997; Vij and Kaur 1999), and rhizome segments (Shimasaki and Uemoto 1990). The major advantage of clonal propagation is that the plantlets produced are usually identical to their parents (clones). This is of great advantage to the cut-flower industry in production of uniform blossoms during predictable periods to meet market demands (Chugh et al. 2009).

Concerning to South American orchids, protocols for clonal large-scale propagation have been reported for Epidendrum ibaguense and Oncidesa 'Gower Ramsey' (the most cultivated orchid hybrid for cut flower) through in vitro culture of nodal segments and inflorescence explants of field-grown adult plants, respectively (Rodrigues et al. 2013; Santana and Chaparro 1999; Table 1).

Table 1 Representative examples of in vitro propagation for South American orchids

\begin{tabular}{llll}
\hline Species & Tissues & Measured parameters & References \\
\hline${\text { Aa } \text { achalensis }^{\mathrm{a}}}$ & Seeds & $\begin{array}{l}\text { Symbiotic seed } \\
\text { germination. }\end{array}$ & $\begin{array}{l}\text { Fracchia et al. } \\
2014 \mathrm{a}\end{array}$ \\
\hline Anathallis adenochila $^{\mathrm{b}}$ & Seedlings $^{\mathrm{d}}$ & $\begin{array}{l}\text { In vitro seedling } \\
\text { survival and growth. }\end{array}$ & $\begin{array}{l}\text { Endres Júnior et al. } \\
2014\end{array}$ \\
\hline Barbosella sp. $^{\mathrm{b}}$ & Seeds & $\begin{array}{l}\text { Asymbiotic seed } \\
\text { germination and in vitro }\end{array}$ & Roberts et al. 2007 \\
& & $\begin{array}{l}\text { seedling development. } \\
\text { Bipinnula fimbriata }\end{array}$ & \\
& Seeds & $\begin{array}{l}\text { Symbiotic seed } \\
\text { germination. } \\
\text { Seed viability and }\end{array}$ & Steinfort et al. 2010 \\
& Seeds & & Pereira et al. 2015 \\
\hline
\end{tabular}


asymbiotic germination, seedling development.

\begin{tabular}{|c|c|c|c|}
\hline $\begin{array}{l}\text { Brachionidium } \\
\text { muscosum }^{\text {b }}\end{array}$ & Seeds & $\begin{array}{l}\text { Asymbiotic seed } \\
\text { germination and in vitro } \\
\text { seedling development. }\end{array}$ & Roberts et al. 2007 \\
\hline $\begin{array}{l}\text { Brasilidium forbesii } \\
\text { (=Oncidium forbesii) }^{\mathrm{b}}\end{array}$ & $\begin{array}{l}\text { Thin cell layers of } \\
\text { protocorms }\end{array}$ & PLBs regeneration. & $\begin{array}{l}\text { Pereira Gomes et al. } \\
2015\end{array}$ \\
\hline Brassavola perrinii $^{b}$ & Seedlings $^{\mathrm{d}}$ & $\begin{array}{l}\text { Multiplication rate and } \\
\text { seedling growth. }\end{array}$ & Pasqual et al. 2011 \\
\hline $\begin{array}{l}\text { Brassavola, Cattleya } \\
\text { and Laelia species } \\
\text { double hybrid ('BCL } \\
\text { Pastoral Innocence') }{ }^{\text {b,c }}\end{array}$ & Seedlings $^{d}$ & Seedling growth. & Prizão et al. 2012 \\
\hline Brassia bidens $^{\mathrm{a}}$ & Seeds & $\begin{array}{l}\text { Asymbiotic seed } \\
\text { germination and in vitro } \\
\text { seedling development. }\end{array}$ & $\begin{array}{l}\text { Monteiro do Rêgo } \\
\text { et al. } 2009\end{array}$ \\
\hline $\begin{array}{l}\text { Brassocattleya } \\
\text { 'Pastoral'b }^{\text {b }}\end{array}$ & Seedlings $^{\mathrm{d}}$ & $\begin{array}{l}\text { Multiplication rate, } \\
\text { height increase and } \\
\text { sugar content reduction. }\end{array}$ & $\begin{array}{l}\text { Cardoso and Ono } \\
2011\end{array}$ \\
\hline Cattleya bicolor $^{\mathrm{b}, \mathrm{c}}$ & Seedlings $^{\mathrm{d}}$ & Seedling growth. & Prizão et al. 2012 \\
\hline 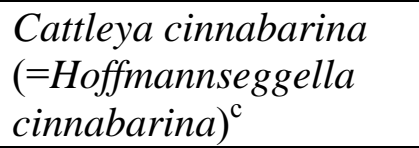 & Seeds & $\begin{array}{l}\text { Asymbiotic seed } \\
\text { germination and in vitro } \\
\text { seedling development. }\end{array}$ & Suzuki et al. 2012 \\
\hline $\begin{array}{l}\text { Cattleya flava (=Laelia } \\
\text { flava) }^{\mathrm{b}}\end{array}$ & Seeds & $\begin{array}{l}\text { Seedling survival and } \\
\text { growth. }\end{array}$ & Moraes et al. 2005 \\
\hline \multirow[t]{3}{*}{ Cattleya intermedia ${ }^{b}$} & Seedlings $^{\mathrm{d}}$ & $\begin{array}{l}\text { Seedling growth during } \\
\text { ex vitro acclimation. }\end{array}$ & Schnitzer et al. 2010 \\
\hline & Seedlings $^{\mathrm{d}}$ & $\begin{array}{l}\text { Seedling survival and } \\
\text { growth during ex vitro } \\
\text { acclimation. }\end{array}$ & $\begin{array}{l}\text { Dorneles and } \\
\text { Trevelin } 2011\end{array}$ \\
\hline & Seeds & $\begin{array}{l}\text { In vitro seedling } \\
\text { survival and growth. }\end{array}$ & Sasamori et al. 2015 \\
\hline $\begin{array}{l}\text { Cattleya intermedia } \mathrm{x} \\
\text { C. purpurata } \\
(=\text { Hadrolaelia } \\
\text { purpurata })^{\mathrm{b}}\end{array}$ & Seedlings $^{d}$ & $\begin{array}{l}\text { Seedling growth during } \\
\text { ex vitro acclimation. }\end{array}$ & Lone et al. 2010 \\
\hline Cattleya jenmanii $^{\text {b }}$ & Seedlings $^{\mathrm{d}}$ & $\begin{array}{l}\text { Anatomical characters } \\
\text { in response to culture } \\
\text { condition. }\end{array}$ & $\begin{array}{l}\text { Torres and Sanabria } \\
2011\end{array}$ \\
\hline \multirow[t]{2}{*}{ Cattleya loddigesii $^{\mathrm{b}, \mathrm{c}}$} & Seeds & $\begin{array}{l}\text { In vitro seedling } \\
\text { growth, plant survival } \\
\text { and growth during ex } \\
\text { vitro acclimation. }\end{array}$ & $\begin{array}{l}\text { Galdiano Júnior et } \\
\text { al. } 2012 \mathrm{a}\end{array}$ \\
\hline & Seedlings $^{\mathrm{d}}$ & Seedling growth. & $\begin{array}{l}\text { Gomes de Araújo et } \\
\text { al. } 2009\end{array}$ \\
\hline $\begin{array}{l}\text { Cattleya longipes } \\
(=\text { Laelia longipes })^{\mathrm{b}, \mathrm{c}}\end{array}$ & Seedlings $^{d}$ & Seedling growth. & Stancato et al. 2008 \\
\hline $\begin{array}{l}\text { Cattleya } \\
\text { lueddemanniana }^{\mathrm{b}}\end{array}$ & Seedlings $^{\mathrm{d}}$ & $\begin{array}{l}\text { Anatomical characters } \\
\text { in response to culture } \\
\text { condition. }\end{array}$ & $\begin{array}{l}\text { Torres and Sanabria } \\
2011\end{array}$ \\
\hline $\begin{array}{l}\text { Cattleya lundii } \\
(=\text { Microlaelia lundii })^{\mathrm{b}, \mathrm{c}}\end{array}$ & Seedlings $^{d}$ & $\begin{array}{l}\text { In vitro seedling growth } \\
\text { and chlorophyll content. }\end{array}$ & Favetta et al. 2017 \\
\hline
\end{tabular}




\begin{tabular}{|c|c|c|c|}
\hline & & $\begin{array}{l}\text { Seedling growth during } \\
\text { ex vitro acclimation. }\end{array}$ & \\
\hline \multirow[t]{2}{*}{ Cattleya maxima $^{\mathrm{b}}$} & Seedlings $^{\mathrm{d}}$ & $\begin{array}{l}\text { Somatic embryogenesis } \\
\text { induction. }\end{array}$ & $\begin{array}{l}\text { Cueva-Agila et al. } \\
2013\end{array}$ \\
\hline & $\begin{array}{l}\text { Leaves of in vitro } \\
\text { seedlings }\end{array}$ & $\begin{array}{l}\text { Somatic embryos } \\
\text { induction, genetic } \\
\text { expression analysis. }\end{array}$ & $\begin{array}{l}\text { Cueva-Agila et al. } \\
2015\end{array}$ \\
\hline Cattleya mendelii $^{\mathrm{b}, \mathrm{c}}$ & Seeds & $\begin{array}{l}\text { Asymbiotic seed } \\
\text { germination and in vitro } \\
\text { seedling development. }\end{array}$ & $\begin{array}{l}\text { Díaz-Álvarez et al. } \\
2015\end{array}$ \\
\hline $\begin{array}{l}\text { Cattleya purpurata } \\
\text { (=Hadrolaelia } \\
\text { purpurata })^{\mathrm{b}}\end{array}$ & Seeds & $\begin{array}{l}\text { Asymbiotic seed } \\
\text { germination and in vitro } \\
\text { seedling development. }\end{array}$ & $\begin{array}{l}\text { De Menezes } \\
\text { Gonçalves et al. } \\
2012\end{array}$ \\
\hline \multirow{2}{*}{$\begin{array}{l}\text { Cattleya purpurata } \\
\text { (=Laelia purpurata) } \\
\text { var. carnea }\end{array}$} & Seedlings ${ }^{\mathrm{d}}$ & $\begin{array}{l}\text { Anatomical analysis of } \\
\text { leaves and roots. }\end{array}$ & $\begin{array}{l}\text { Da Silva Júnior et } \\
\text { al. } 2012\end{array}$ \\
\hline & Seedlings ${ }^{\mathrm{d}}$ & $\begin{array}{l}\text { In vitro seedling } \\
\text { growth, root anatomical } \\
\text { changes and } \\
\text { chlorophyll content. }\end{array}$ & $\begin{array}{l}\text { Da Silva Júnior et } \\
\text { al. } 2013\end{array}$ \\
\hline Cattleya quadricolor ${ }^{b}$ & Seeds & $\begin{array}{l}\text { Asymbiotic seed } \\
\text { germination and in vitro } \\
\text { seedling development. }\end{array}$ & $\begin{array}{l}\text { Díaz-Álvarez et al. } \\
2015\end{array}$ \\
\hline Cattleya tigrina $^{b}$ & $\begin{array}{l}\text { Leaves of in vitro } \\
\text { seedlings }{ }^{d}\end{array}$ & $\begin{array}{l}\text { DNA methylation and } \\
\text { endogenous polyamine } \\
\text { levels during PLBs } \\
\text { induction. }\end{array}$ & Almeida et al. 2017 \\
\hline \multirow[t]{2}{*}{ Cattleya trianae $^{\mathrm{b}}$} & Seedlings $^{\mathrm{d}}$ & $\begin{array}{l}\text { Ex vitro seedling } \\
\text { survival and growth. }\end{array}$ & Franco et al. 2007 \\
\hline & Seedlings $^{\mathrm{d}}$ & Seedling growth. & $\begin{array}{l}\text { Galdiano Júnior et } \\
\text { al. } 2012 \mathrm{~b}\end{array}$ \\
\hline Cattleya violacea ${ }^{b}$ & Seeds & $\begin{array}{l}\text { Asymbiotic seed } \\
\text { germination and in vitro } \\
\text { seedling development. }\end{array}$ & $\begin{array}{l}\text { Galdiano Júnior et } \\
\text { al. } 2013\end{array}$ \\
\hline \multirow[t]{3}{*}{ Cattleya walkeriana $^{b}$} & Seedlings $^{\mathrm{d}}$ & Seedling growth. & Dignart et al. 2009 \\
\hline & Seedlings $^{\mathrm{d}}$ & $\begin{array}{l}\text { Seedling survival and } \\
\text { growth during ex vitro } \\
\text { acclimation. }\end{array}$ & $\begin{array}{l}\text { Galdiano Júnior et } \\
\text { al. } 2011\end{array}$ \\
\hline & Seeds & $\begin{array}{l}\text { Seed germination } \\
\text { morphologic analysis } \\
\text { and seedling growth. }\end{array}$ & $\begin{array}{l}\text { Galdiano Júnior et } \\
\text { al. } 2014\end{array}$ \\
\hline \multirow[t]{2}{*}{ 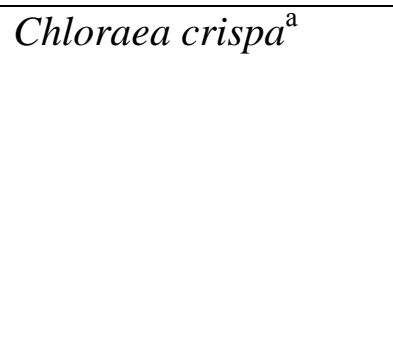 } & Seeds & $\begin{array}{l}\text { Asymbiotic seed } \\
\text { germination and in vitro } \\
\text { seedling development. }\end{array}$ & Pereira et al. 2017 \\
\hline & Seeds & $\begin{array}{l}\text { Asymbiotic seed } \\
\text { germination and } \\
\text { embryogenic calli } \\
\text { formation. }\end{array}$ & Quiroz et al. 2017 \\
\hline \multirow[t]{2}{*}{ Chloraea gavilu } & Seeds & $\begin{array}{l}\text { Asymbiotic seed } \\
\text { germination and in vitro } \\
\text { seedling development. }\end{array}$ & Pereira et al. 2017 \\
\hline & Seeds, protocorms, & Asymbiotic seed & Romero et al. 2018 \\
\hline
\end{tabular}




\begin{tabular}{|c|c|c|c|}
\hline & $\begin{array}{l}\text { thin cell layers from } \\
\text { protocorms and } \\
\text { seedling leaves }\end{array}$ & $\begin{array}{l}\text { germination, in vitro } \\
\text { seedling development, } \\
\text { PLBs induction. }\end{array}$ & \\
\hline Chloraea riojana $^{\mathrm{a}}$ & Seeds & $\begin{array}{l}\text { Symbiotic seed } \\
\text { germination. }\end{array}$ & Fracchia et al. 2016 \\
\hline Chloraea virescens $^{\mathrm{a}}$ & Seeds & $\begin{array}{l}\text { Asymbiotic seed } \\
\text { germination and in vitro } \\
\text { seedling development. }\end{array}$ & Pereira et al. 2017 \\
\hline \multirow[t]{2}{*}{ Comparettia falcata $^{\mathrm{b}}$} & Seeds & $\begin{array}{l}\text { Asymbiotic seed } \\
\text { germination and in vitro } \\
\text { seedling development. }\end{array}$ & $\begin{array}{l}\text { Pedroza-Manrique } \\
\text { et al. } 2005\end{array}$ \\
\hline & Seeds & $\begin{array}{l}\text { Symbiotic and } \\
\text { asymbiotic seed } \\
\text { germination. }\end{array}$ & Chávez et al. 2014 \\
\hline 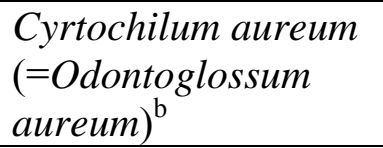 & Seeds & $\begin{array}{l}\text { Asymbiotic seed } \\
\text { germination and in vitro } \\
\text { seedling development. }\end{array}$ & Roberts et al. 2007 \\
\hline $\begin{array}{l}\text { Cyrtochilum } \\
\text { caespitosum } \\
\text { (=Rusbyella } \\
\text { caespitose) }^{\mathrm{b}}\end{array}$ & Seeds & $\begin{array}{l}\text { Asymbiotic seed } \\
\text { germination and in vitro } \\
\text { seedling development. }\end{array}$ & Roberts et al. 2007 \\
\hline Cyrtochilum loxense & Seedlings $^{\mathrm{d}}$ & $\begin{array}{l}\text { Somatic Embryogenesis } \\
\text { Receptor-like Kinase } \\
\text { (SERK) expression } \\
\text { analysis. }\end{array}$ & $\begin{array}{l}\text { Cueva-Agila et al. } \\
2012\end{array}$ \\
\hline $\begin{array}{l}\text { Cyrtopodium } \\
\text { brandonianum }^{\text {a }}\end{array}$ & $\begin{array}{l}\text { Root-tips from in } \\
\text { vitro seedlings }{ }^{\mathrm{d}}\end{array}$ & $\begin{array}{l}\text { Adventitious shoot } \\
\text { organogenesis. }\end{array}$ & $\begin{array}{l}\text { Flachsland et al. } \\
2011\end{array}$ \\
\hline \multirow[t]{4}{*}{$\begin{array}{l}\text { Cyrtopodium } \\
\text { glutiniferum }^{\mathrm{a}, \mathrm{c}}\end{array}$} & Seeds & $\begin{array}{l}\text { Asymbiotic seed } \\
\text { germination and in vitro } \\
\text { seedling development. }\end{array}$ & Vogel et al. 2011 \\
\hline & Seeds & Symbiotic seed & Rodrigues \\
\hline & & $\begin{array}{l}\text { germination and in vitro } \\
\text { seedling development, } \\
\text { ex vitro growth. }\end{array}$ & $\begin{array}{l}\text { Guimarães et al. } \\
2013\end{array}$ \\
\hline & Seeds & $\begin{array}{l}\text { Symbiotic seed } \\
\text { germination, in vitro } \\
\text { seedling development, } \\
\text { fungal colonization. }\end{array}$ & $\begin{array}{l}\text { Corrêa Pereira et al. } \\
2015\end{array}$ \\
\hline $\begin{array}{l}\text { Cyrtopodium } \\
\text { paludicolum }^{\text {a }}\end{array}$ & Seeds & $\begin{array}{l}\text { Symbiotic and } \\
\text { asymbiotic seed } \\
\text { germination. }\end{array}$ & $\begin{array}{l}\text { De Carvalho et al. } \\
2017\end{array}$ \\
\hline $\begin{array}{l}\text { Cyrtopodium } \\
\text { saintlegerianum }^{\mathrm{b}}\end{array}$ & $\begin{array}{l}\text { Seeds and } \\
\text { seedlings } \mathrm{d}\end{array}$ & $\begin{array}{l}\text { Asymbiotic seed } \\
\text { germination and in vitro } \\
\text { seedling development, } \\
\text { plant growth during ex } \\
\text { vitro acclimation. }\end{array}$ & $\begin{array}{l}\text { Rodrigues et al. } \\
2015\end{array}$ \\
\hline Encyclia cordigera $^{b}$ & Seedlings $^{\mathrm{d}}$ & $\begin{array}{l}\text { In vitro seedling } \\
\text { growth. }\end{array}$ & $\begin{array}{l}\text { Mantovani et al. } \\
2016\end{array}$ \\
\hline Encyclia microtos $^{b}$ & Seedlings $^{\mathrm{d}}$ & $\begin{array}{l}\text { In vitro seedling } \\
\text { development and } \\
\text { multiplication. }\end{array}$ & $\begin{array}{l}\text { Condemarín- } \\
\text { Montealegre et al. } \\
2007\end{array}$ \\
\hline Encyclia randii ${ }^{\mathrm{b}}$ & Seeds & Asymbiotic seed & Gonçalves et al., \\
\hline
\end{tabular}


germination and in vitro 2012

seedling development.

\begin{tabular}{|c|c|c|c|}
\hline Epidendrum cardenasii $^{b}$ & Seeds & $\begin{array}{l}\text { Asymbiotic seed } \\
\text { germination and in vitro } \\
\text { seedling development. }\end{array}$ & Roberts et al. 2007 \\
\hline Epidendrum ibaguense $^{\mathrm{b}}$ & $\begin{array}{l}\text { Nodal segments of } \\
\text { field-grown plants }\end{array}$ & $\begin{array}{l}\text { Contamination control } \\
\text { and shoot growth. }\end{array}$ & $\begin{array}{l}\text { Rodrigues et al. } \\
2013\end{array}$ \\
\hline Epidendrum nocturnum ${ }^{\mathrm{b}}$ & $\begin{array}{l}\text { Seeds and } \\
\text { seedlings }\end{array}$ & $\begin{array}{l}\text { In vitro seedling growth } \\
\text { with and without } \\
\text { michorrization. }\end{array}$ & $\begin{array}{l}\text { Sousa Silva et al. } \\
2016\end{array}$ \\
\hline Epidendrum secundum $^{b}$ & Seeds & $\begin{array}{l}\text { Symbiotic seed } \\
\text { germination and in vitro } \\
\text { seedling development. }\end{array}$ & $\begin{array}{l}\text { Corrêa Pereira et al. } \\
2011\end{array}$ \\
\hline & Seeds & Seedling growth. & Massaro et al. 2012 \\
\hline Gavilea australis $^{\mathrm{a}}$ & Seeds & $\begin{array}{l}\text { Symbiotic seed } \\
\text { germination. }\end{array}$ & $\begin{array}{l}\text { Fracchia et al. } \\
2014 b\end{array}$ \\
\hline $\begin{array}{l}\text { Gomesa flexuosa } \\
(=\text { Oncidium flexuosum })^{b}\end{array}$ & Seedlings $^{\mathrm{d}}$ & $\begin{array}{l}\text { In vitro seedling } \\
\text { growth. }\end{array}$ & Caovila et al. 2016 \\
\hline Gongora quinquenervis $^{\mathrm{a}}$ & Seeds & $\begin{array}{l}\text { In vitro seedling } \\
\text { development. }\end{array}$ & $\begin{array}{l}\text { Cavalcante Martini } \\
\text { et al. } 2001\end{array}$ \\
\hline Habenaria bractescens $^{\mathrm{a}}$ & $\begin{array}{l}\text { Multinodal segment } \\
\text { from in vitro } \\
\text { seedlings }{ }^{\mathrm{d}}\end{array}$ & $\begin{array}{l}\text { Upright leafy shoots, } \\
\text { swollen buds, and root } \\
\text { tubers. }\end{array}$ & Medina et al. 2009 \\
\hline $\begin{array}{l}\text { Laeliocattleya } \mathrm{x} \\
\text { Brassolaeliocattleya } \\
\text { hibryd }^{\text {b }}\end{array}$ & Seedlings $^{\mathrm{d}}$ & $\begin{array}{l}\text { Multiplication rate and } \\
\text { seedling growth. }\end{array}$ & Pasqual et al. 2011 \\
\hline $\begin{array}{l}\text { Laeliocattleya hybrid } \\
\text { (Hadrolaelia purpurata } \\
\text { x Cattleya intermedia) }\end{array}$ & Seedlings $^{\mathrm{d}}$ & In vitro seedling growth & $\begin{array}{l}\text { De Menezes } \\
\text { Gonçalves et al. } \\
2016\end{array}$ \\
\hline $\begin{array}{l}\text { Masdevallia } \\
\text { yungasensis }^{\mathrm{b}}\end{array}$ & Seeds & $\begin{array}{l}\text { Asymbiotic seed } \\
\text { germination and in vitro } \\
\text { seedling development. }\end{array}$ & Roberts et al. 2007 \\
\hline Miltonia clowesii $^{\mathrm{b}}$ & Seedlings $^{\mathrm{d}}$ & $\begin{array}{l}\text { Seedling growth during } \\
\text { ex vitro acclimation. }\end{array}$ & Schnitzer et al. 2010 \\
\hline Miltonia flavescens ${ }^{\mathrm{b}}$ & Seeds & $\begin{array}{l}\text { Seedling survival and } \\
\text { growth. }\end{array}$ & Moraes et al. 2005 \\
\hline Miltonia spectabilis ${ }^{\mathrm{b}}$ & Seedlings $^{\mathrm{d}}$ & Seedling growth. & Stancato et al. 2008 \\
\hline $\begin{array}{l}\text { Odontoglossum } \\
\text { gloriosum }^{\mathrm{b}}\end{array}$ & Seeds & $\begin{array}{l}\text { Asymbiotic seed } \\
\text { germination. }\end{array}$ & $\begin{array}{l}\text { Pedroza-Manrique } \\
\text { and Mican- } \\
\text { Gutiérrez } 2006\end{array}$ \\
\hline $\begin{array}{l}\text { Oncidesa }(=\text { Oncidium }) \\
\text { 'Gower Ramsey'b }\end{array}$ & $\begin{array}{l}\text { Floral buds of } \\
\text { inflorescence from } \\
\text { ex vitro plant }\end{array}$ & $\begin{array}{l}\text { PLB formation, } \\
\text { multiplication and } \\
\text { plantlets regeneration. }\end{array}$ & $\begin{array}{l}\text { Santana and } \\
\text { Chaparro } 1999\end{array}$ \\
\hline Oncidium baueri $^{\mathrm{b}}$ & Seedlings ${ }^{\mathrm{d}}$ & Seedling growth. & Sorace et al. 2008 \\
\hline Oncidium leucochilum $^{b}$ & Shoots $^{\mathrm{d}}$ & $\begin{array}{l}\text { In vitro multiplication, } \\
\text { elongation and rooting; } \\
\text { ex vitro acclimation. }\end{array}$ & Da Silva et al. 2014 \\
\hline Oncidium trulliferum ${ }^{b}$ & Seeds & $\begin{array}{l}\text { Seedling survival and } \\
\text { growth. }\end{array}$ & Moraes et al. 2005 \\
\hline Schomburgkia crispa ${ }^{b, c}$ & $\begin{array}{l}\text { Nodal segments } \\
\text { from in vitro plants }\end{array}$ & $\begin{array}{l}\text { In vitro multiplication } \\
\text { and rooting. }\end{array}$ & Pereira et al. 2018 \\
\hline
\end{tabular}




\begin{tabular}{|c|c|c|c|}
\hline Schomburgkia gloriosa $^{\mathrm{b}}$ & Seeds & Seedling growth. & Dezan et al. 2012 \\
\hline $\begin{array}{l}\text { Sophronitis tenebrosa } \\
(=\text { Laelia tenebrosa })^{\mathrm{b}}\end{array}$ & Seedlings $^{\mathrm{d}}$ & Seedling growth. & Stancato et al. 2008 \\
\hline Telipogon sp. & Seeds & $\begin{array}{l}\text { Asymbiotic seed } \\
\text { germination and in vitro } \\
\text { seedling development. }\end{array}$ & Roberts et al. 2007 \\
\hline Vanilla planifolia ${ }^{\mathrm{a}, \mathrm{b}}$ & Seeds & $\begin{array}{l}\text { Effect of scarification } \\
\text { on asymbiotic seed } \\
\text { germination and in vitro } \\
\text { seedling development. }\end{array}$ & $\begin{array}{l}\text { Pedroso-de-Moraes } \\
\text { et al. } 2012\end{array}$ \\
\hline
\end{tabular}

${ }^{\mathrm{a}}$ Terrestrial

${ }^{\mathrm{b}}$ Epiphyte

${ }^{\mathrm{c}}$ Lithophyte

${ }^{\mathrm{d}}$ Seed-derived material

\section{In Vitro Conservation Approaches in Orchids}

All types of in vitro-cultured materials that have been used for mass rapid propagation of orchids may be also utilized for conservation purposes (Popova et al. 2016). For example, over $90 \%$ of seed-derived in vitro seedlings of Dendrobium officinale tolerated 12 months of storage at $4{ }^{\circ} \mathrm{C}$ in darkness without subculture (Shi et al. 2000). Likewise, in vitro plantlets of Dendrobium draconis and Ipsea malabarica maintained high viability during storage at $25^{\circ} \mathrm{C}$ for 6 and 27 months respectively (Martin and Pradeep 2003; Rangsayatorn et al. 2009). More recently, in vitro slow growth techniques and storage at low positive temperatures (from 0 to $16{ }^{\circ} \mathrm{C}$ ) have proved to be effective for some Dendrobium species (Teixeira da Silva et al. 2014). However, short to medium-term in vitro conservation is relatively labour-intensive and costly; moreover, phenotypical and genetic variations in the course of repeated subcultures have been documented for orchid materials (Arditti 2008; Khoddamzadeh et al. 2010; Teixeira da Silva et al. 2014; Tokuhara and Mii 1998). These limitations have promoted the development of less expensive and more reliable conservation methods such as cryopreservation, which allows safe and long-term storage of orchid germplasm once an appropriate protocol is designed and validated for each genotype (Popova et al. 2016).

Cryopreservation, i.e., storage of samples at ultralow temperature of $\mathrm{LN}\left(-196^{\circ} \mathrm{C}\right)$, has become the most important tool to modern science for the long-term storage of plant materials since it provides the possibility of significantly extending the storage period with the maximum genetic stability. At this temperature, all cellular divisions and metabolic processes are stopped. The plant material can thus be stored without alteration or modification for a theoretically unlimited period of time (Ashmore 1997; Engelmann 2011). However, cryopreservation presents a series of problems mainly associated to the initial moisture content (MC) of sample and the alterations to which the material is subjected during the process of cooling/rewarming. Both factors should be evaluated for each biological material before using any cryopreservation method. The MC of tissues is the most critical factor for successful cryopreservation (Vertucci and Roos 1993). Optimal survival is generally obtained when samples are frozen with a MC comprised between $10 \%$ and $20 \%$ (fresh weight basis) (Engelmann 2011). Likewise, the use of proper cryoprotectants [glycerol, ethylene glycol, dimethylsulfoxide (DMSO), and plant vitrification solutions (PVS)] can increase the success 
of cryopreservation protocols by suppressing ice crystallization during cooling to and warming from LN (Sakai et al. 1990).

Current work in cryopreservation has permitted the storage of virtually all explant types for many plant species (Ashmore et al. 2011; Engelmann 2004; 2011; González-Arnao and Engelmann 2006; González-Arnao et al. 2008; 2017; Panis and Lambardi 2006; Uragami 1993). In orchids, cryopreservation has been an efficient means of conserving seeds and pollen (e.g., Dolce et al. 2016; Dolce and González-Arnao 2018; Flachsland et al. 2006; Hay et al. 2010; Koopowitz 1986; Koopowitz and Thornhill, 1994; Mweetwa et al. 2007; Popov et al. 2004; Pritchard 1984; Vendrame et al. 2007b; 2008; Surenciski et al. 2012). By contrast, attempts to cryopreserve somatic explants (i.e., clonal material) are scarce and have resulted in variable regrowth (Dolce et al. 2018; González-Arnao et al. 2009; Hernández-Ramírez et al. 2014; Kondo et al. 2001; Lurswijidjarus and Thammasiri 2004; $\mathrm{Na}$ and Kondo 1996; Thinh and Takagi 2000; Tsukazaki et al. 2000).

Concerning to South American orchids, to date researches about ex situ germplasm conservation is reported for 30 species (Table 2). This is quite worrying when we consider the orchid megadiversity that occur in South America (more than 10,000 species) and the orchid conservation status in the continent.

Table 2 Conservation methods for South American orchids

\begin{tabular}{|c|c|c|c|}
\hline Species & Tissues & Conservation method & References \\
\hline 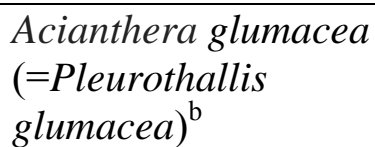 & Seeds & Storage at $5{ }^{\circ} \mathrm{C}$ with $6 \% \mathrm{MC}$. & $\begin{array}{l}\text { Alvarez-Pardo and } \\
\text { Ferreira } 2006\end{array}$ \\
\hline Bifrenaria inodora ${ }^{\mathrm{b}}$ & Seeds & Storage at $5{ }^{\circ} \mathrm{C}$ with $6 \% \mathrm{MC}$. & $\begin{array}{l}\text { Alvarez-Pardo and } \\
\text { Ferreira } 2006\end{array}$ \\
\hline 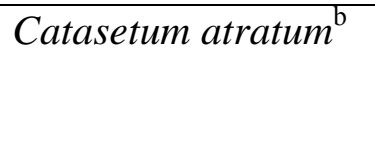 & Seeds & $\begin{array}{l}\text { Cryostorage by vitrification } \\
\text { technique with PVS2 } \\
\text { solution. }\end{array}$ & Suzuki et al. 2018 \\
\hline \multirow[t]{2}{*}{ Cattleya bicolor $^{\mathrm{b}, \mathrm{c}}$} & Seeds & Storage at $5{ }^{\circ} \mathrm{C}$ with $6 \% \mathrm{MC}$. & $\begin{array}{l}\text { Alvarez-Pardo and } \\
\text { Ferreira } 2006\end{array}$ \\
\hline & Seeds & $\begin{array}{l}\text { Storage at } 10 \text { and } 25^{\circ} \mathrm{C} \text { over } \\
\text { silica gel. }\end{array}$ & Mora et al. 2008 \\
\hline 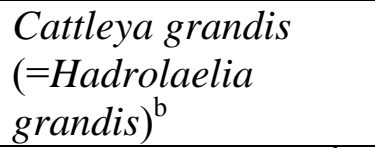 & Seeds & Storage at -20 and $-80^{\circ} \mathrm{C}$ & $\begin{array}{l}\text { Vudala and Ribas } \\
2017\end{array}$ \\
\hline Cattleya granulosa $^{\mathrm{b}}$ & Seeds & Storage at $-18^{\circ} \mathrm{C}$. & Hosomi et al. 2012 \\
\hline Cattleya hegeriana $^{\mathrm{c}}$ & Seeds & Storage at $-18^{\circ} \mathrm{C}$ & Hosomi et al. 2012 \\
\hline \multirow[t]{3}{*}{ Cattleya intermedia ${ }^{\mathrm{b}}$} & Seeds & $\begin{array}{l}\text { Storage at }-18,5 \text { and } 25^{\circ} \mathrm{C}, \\
\text { seeds with } 6 \% \mathrm{MC} \text {. }\end{array}$ & $\begin{array}{l}\text { Alvarez-Pardo et al. } \\
2006\end{array}$ \\
\hline & Seeds & Storage at $5{ }^{\circ} \mathrm{C}$ with $6 \% \mathrm{MC}$. & $\begin{array}{l}\text { Alvarez-Pardo and } \\
\text { Ferreira } 2006\end{array}$ \\
\hline & Seeds & Storage at $-18^{\circ} \mathrm{C}$ & Hosomi et al. 2012 \\
\hline $\begin{array}{l}\text { Cattleya intermedia } \\
\text { var. pallida }\end{array}$ & Seeds & Storage at $5{ }^{\circ} \mathrm{C}$ with $6 \% \mathrm{MC}$. & $\begin{array}{l}\text { Alvarez-Pardo and } \\
\text { Ferreira } 2006\end{array}$ \\
\hline Cattleya labiata $^{\mathrm{b}}$ & Seeds & Storage at $5{ }^{\circ} \mathrm{C}$ with $6 \% \mathrm{MC}$. & $\begin{array}{l}\text { Alvarez-Pardo and } \\
\text { Ferreira } 2006\end{array}$ \\
\hline Cattleya mossiae & Seeds & Storage at $-18^{\circ} \mathrm{C}$. & Hosomi et al. 2012 \\
\hline Cattleya purpurata & Seeds & Storage at $-18^{\circ} \mathrm{C}$. & Hosomi et al. 2012 \\
\hline
\end{tabular}




\begin{tabular}{|c|c|c|c|}
\hline $\begin{array}{l}(=\text { Hadrolaelia } \\
\text { purpurata and Laelia } \\
\text { purpurata })^{\mathrm{b}}\end{array}$ & Seeds & Storage at $5{ }^{\circ} \mathrm{C}$ with $6 \% \mathrm{MC}$. & $\begin{array}{l}\text { Alvarez-Pardo and } \\
\text { Ferreira } 2006\end{array}$ \\
\hline 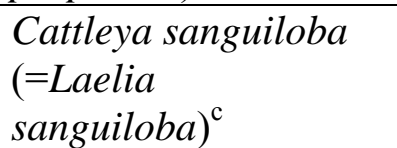 & Seeds & Storage at $-18^{\circ} \mathrm{C}$. & Hosomi et al. 2012 \\
\hline Cattleya tenuis $^{\mathrm{b}}$ & Seeds & Storage at $-18^{\circ} \mathrm{C}$. & Hosomi et al. 2012 \\
\hline Cattleya tigrina $^{\mathrm{b}}$ & Seeds & Storage at $-18^{\circ} \mathrm{C}$. & Hosomi et al. 2012 \\
\hline \multirow[t]{2}{*}{ 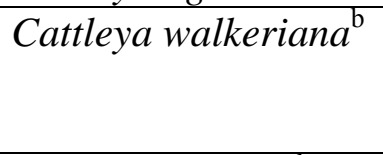 } & Seeds & Storage at $-18^{\circ} \mathrm{C}$. & Hosomi et al. 2012 \\
\hline & Seeds & $\begin{array}{l}\text { Cryostorage by vitrification } \\
\text { method with PVS } 2 \text { solution. }\end{array}$ & $\begin{array}{l}\text { Galdiano Júnior et al. } \\
2017\end{array}$ \\
\hline \multirow[t]{2}{*}{ Cohniella cepula $^{\mathrm{b}}$} & Pollinia & $\begin{array}{l}\text { Storage at }-70 \text { and }-196^{\circ} \mathrm{C} \\
\text { without pre-treatment. }\end{array}$ & Dolce et al. 2016 \\
\hline & Seeds & $\begin{array}{l}\text { Cryostorage without seed pre- } \\
\text { treatment. }\end{array}$ & $\begin{array}{l}\text { Dolce and González- } \\
\text { Arnao } 2018\end{array}$ \\
\hline $\begin{array}{l}\text { Cyrtopodium } \\
\text { hatschbachii }^{\mathrm{b}, \mathrm{c}}\end{array}$ & $\begin{array}{l}\text { Immature } \\
\text { seeds }\end{array}$ & $\begin{array}{l}\text { Cryostorage by } \\
\text { encapsulation-dehydration } \\
\text { technique. }\end{array}$ & Surenciski et al. 2012 \\
\hline $\begin{array}{l}\text { Encyclia } \\
\text { odoratissima }^{\mathrm{b}}\end{array}$ & Seeds & Storage at $5{ }^{\circ} \mathrm{C}$ with $6 \% \mathrm{MC}$. & $\begin{array}{l}\text { Alvarez-Pardo and } \\
\text { Ferreira } 2006\end{array}$ \\
\hline Encyclia pygmaea $^{b}$ & Seeds & Storage at $5{ }^{\circ} \mathrm{C}$ with $6 \% \mathrm{MC}$. & $\begin{array}{l}\text { Alvarez-Pardo and } \\
\text { Ferreira } 2006\end{array}$ \\
\hline $\begin{array}{l}\text { Epidendrum } \\
\text { anderssonii }^{\mathrm{b}}\end{array}$ & Seeds & $\begin{array}{l}\text { Cryostorage by vitrification } \\
\text { method. }\end{array}$ & Cerna et al. 2018 \\
\hline $\begin{array}{l}\text { Epidendrum } \\
\text { fulgens } \mathrm{a}, \mathrm{b}\end{array}$ & Seeds & Storage at $5{ }^{\circ} \mathrm{C}$ with $6 \% \mathrm{MC}$. & $\begin{array}{l}\text { Alvarez-Pardo and } \\
\text { Ferreira } 2006\end{array}$ \\
\hline $\begin{array}{l}\text { Epidendrum } \\
\text { quitensium }^{\mathrm{b}}\end{array}$ & Seeds & $\begin{array}{l}\text { Cryostorage by vitrification } \\
\text { method. }\end{array}$ & Cerna et al. 2018 \\
\hline $\begin{array}{l}\text { Gomesa bifolia } \\
(=\text { Oncidium } \\
\text { bifolium })^{\mathrm{b}}\end{array}$ & $\begin{array}{l}\text { Seeds and } \\
\text { protocorms }\end{array}$ & $\begin{array}{l}\text { Cryostorage by } \\
\text { encapsulation-dehydration } \\
\text { technique. }\end{array}$ & $\begin{array}{l}\text { Flachsland et al. } \\
2006\end{array}$ \\
\hline 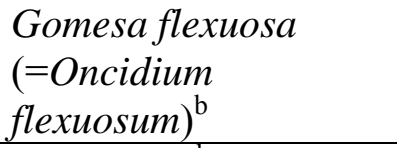 & Seeds & Storage at $5{ }^{\circ} \mathrm{C}$ with $6 \% \mathrm{MC}$. & $\begin{array}{l}\text { Alvarez-Pardo and } \\
\text { Ferreira } 2006\end{array}$ \\
\hline Grobya sp. ${ }^{b}$ & Seeds & Storage at $5{ }^{\circ} \mathrm{C}$ with $6 \% \mathrm{MC}$. & $\begin{array}{l}\text { Alvarez-Pardo and } \\
\text { Ferreira } 2006\end{array}$ \\
\hline $\begin{array}{l}\text { Laeliocattleya } \\
\text { natural hybrid }^{\mathrm{b}}\end{array}$ & Seeds & Storage at $5{ }^{\circ} \mathrm{C}$ with $6 \% \mathrm{MC}$. & $\begin{array}{l}\text { Alvarez-Pardo and } \\
\text { Ferreira } 2006\end{array}$ \\
\hline Maxillaria picta ${ }^{b}$ & Seeds & Storage at $5{ }^{\circ} \mathrm{C}$ with $6 \% \mathrm{MC}$. & $\begin{array}{l}\text { Alvarez-Pardo and } \\
\text { Ferreira } 2006\end{array}$ \\
\hline $\begin{array}{l}\text { Oncidium } \\
\text { enderianum }^{\mathrm{b}}\end{array}$ & Seeds & Storage at $5{ }^{\circ} \mathrm{C}$ with $6 \% \mathrm{MC}$. & $\begin{array}{l}\text { Alvarez-Pardo and } \\
\text { Ferreira } 2006\end{array}$ \\
\hline Sobralia rosea ${ }^{\mathrm{a}}$ & Seeds & $\begin{array}{l}\text { Cryostorage by vitrification } \\
\text { method. }\end{array}$ & Cerna et al. 2018 \\
\hline 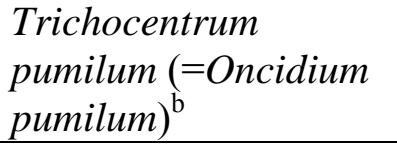 & Seeds & Storage at $5{ }^{\circ} \mathrm{C}$ with $6 \% \mathrm{MC}$. & $\begin{array}{l}\text { Alvarez-Pardo and } \\
\text { Ferreira } 2006\end{array}$ \\
\hline $\begin{array}{l}{ }^{\mathrm{a}} \text { Terrestrial } \\
{ }^{\mathrm{b}} \text { Epiphyte } \\
{ }^{\mathrm{c}} \text { Lithophyte }\end{array}$ & & & \\
\hline
\end{tabular}


Modern propagation and production technology has made orchids accessible to a much broader section of the society. Cost efficient protocols for mass propagation of rare, threatened and endangered orchids, as well as new orchid hybrids, have to be developed further in order to commercialize and conserve them. For this, critical insights into the physiology and factors affecting growth and development of orchids are essential. The floriculture industry as well as conservation efforts would get a huge boost if the protocols developed in the laboratories can be further standardized and transferred to industries and organizations involved with ex situ conservation of this alluring flower (Chugh et al. 2009).

Table 3 summarizes information about scientific works recorded so far for different South American countries regarding in vitro propagation and germplasm conservation of native orchids from this continent, according to the Scopus database (key words: "propagation AND orchid", "conservation AND orchid", "cryopreservation AND orchid"). It could be noted that Brazil has the highest number of published works both on propagation and germplasm conservation, while for some countries only researches referring to propagation of native orchid species are reported and for other countries (Guyana, Paraguay, Trinidad and Tobago, Suriname, Uruguay) there were no registered works in any of the topics.

Table 3 Scientific articles published by South American countries (according to Scopus database, at 11-01-2018).

\begin{tabular}{|c|c|c|c|}
\hline Country & Topic & $\begin{array}{l}\text { Number of } \\
\text { scientific } \\
\text { articles }\end{array}$ & References \\
\hline \multirow[t]{2}{*}{ Argentina } & Propagation & 5 & $\begin{array}{l}\text { Flachsland et al. 2011; Fracchia et al. 2014a,b; } \\
\text { 2016; Medina et al. } 2009\end{array}$ \\
\hline & Conservation & 5 & $\begin{array}{l}\text { Dolce et al. 2016; Duarte et al. 2017; Flachsland } \\
\text { et al. 2006; Surenciski et al. 2007; } 2012\end{array}$ \\
\hline \multirow[t]{2}{*}{ Bolivia } & Propagation & 1 & Roberts et al. 2007. \\
\hline & Conservation & 0 & \\
\hline Brazil & Propagation & 48 & $\begin{array}{l}\text { Almeida et al. 2017; Caovila et al. 2016; } \\
\text { Cardoso and Ono 2011; Cavalcante Martini et } \\
\text { al. 2001; Corrêa Pereira et al. 2011; 2015; Da } \\
\text { Silva et al. 2014; Da Silva Júnior et al. 2012; } \\
\text { 2013; De Carvalho et al. 2018; De Conti et al. } \\
\text { 2018; De Melo Ferreira et al. 2017; De } \\
\text { Menezes Gonçalves et al. 2012; 2016; Dezan et } \\
\text { al. 2012; Dignart et al. 2009; Dorneles and } \\
\text { Trevelin 2011; Endres Júnior et al. 2014; } \\
\text { Favetta et al. 2017; Galdiano Júnior et al. 2011; } \\
\text { 2012a,b; 2013; 2014; Gomes de Araújo et al. } \\
\text { 2009; Hosomi et al. 2017; Lando et al. 2016; } \\
\text { Lone et al. 2010; Mantovani et al. 2016; } \\
\text { Massaro et al. 2012; Monteiro do Rêgo et al. } \\
\text { 2009; Moraes et al. 2005; Pasqual et al. 2011; } \\
\text { Pedroso-de-Moraes et al. 2012; Pereira et al. } \\
\text { 2018; Pereira Gomes et al. 2015; Prizão et al. } \\
\text { 2012; Rodrigues et al. 2013; Rodrigues et al. } \\
\text { 2015; Rodrigues Guimarães et al. 2013; } \\
\text { Sasamori et al. 2015; Schnitzer et al. 2010; } \\
\text { Sorace et al. 2008; Sousa Silva et al. 2016; }\end{array}$ \\
\hline
\end{tabular}


Stancato et al. 2008; Suzuki et al. 2012; Villa et al. 2014; Vogel and Macedo 2011

Conservation $\quad 7 \quad$ Alvarez-Pardo and Ferreira 2006; Galdiano
Júnior et al. 2017; Hosomi et al. 2011; 2012; Mora et al 2008; Suzuki et al. 2018; Vudala and Ribas 2017

\begin{tabular}{|c|c|c|c|}
\hline \multirow[t]{2}{*}{ Chile } & Propagation & 5 & $\begin{array}{l}\text { Pereira et al. 2015; 2017; Quiroz et al. 2017; } \\
\text { Romero et al. 2018; Steinfort et al. } 2010\end{array}$ \\
\hline & Conservation & 0 & - \\
\hline \multirow[t]{2}{*}{ Colombia } & Propagation & 6 & $\begin{array}{l}\text { Chávez et al. 2014; Díaz-Álvarez et al. 2015; } \\
\text { Franco et al. 2007; Pedroza-Manrique and } \\
\text { Mican-Gutiérrez 2006; Pedroza-Manrique et al. } \\
\text { 2005; Santana and Chaparro } 1999\end{array}$ \\
\hline & Conservation & 1 & Flanagan and Mosquera Espinosa 2016 \\
\hline \multirow[t]{2}{*}{ Ecuador } & Propagation & 3 & Cueva-Agila et al. 2012; 2015a; 2015b \\
\hline & Conservation & 1 & Cerna et al. 2018 \\
\hline \multirow{2}{*}{$\begin{array}{l}\text { French } \\
\text { Guiana, } \\
\text { Guyana, and } \\
\text { Suriname } \\
\end{array}$} & Propagation & 0 & - \\
\hline & Conservation & 0 & - \\
\hline \multirow[t]{2}{*}{ Paraguay } & Propagation & 0 & - \\
\hline & Conservation & 0 & - \\
\hline \multirow[t]{2}{*}{ Peru } & Propagation & 1 & Condemarín-Montealegre et al. 2007 \\
\hline & Conservation & 0 & - \\
\hline \multirow{2}{*}{$\begin{array}{l}\text { Trinidad and } \\
\text { Tobago }\end{array}$} & Propagation & 0 & - \\
\hline & Conservation & 0 & - \\
\hline \multirow[t]{2}{*}{ Uruguay } & Propagation & 0 & - \\
\hline & Conservation & 0 & - \\
\hline \multirow[t]{2}{*}{ Venezuela } & Propagation & 1 & Torres and Sanabria 2011 \\
\hline & Conservation & 0 & - \\
\hline
\end{tabular}

\section{In Vitro Propagation and Germplasm Conservation of Wild Orchids from Argentina. Study Cases.}

In Argentina have been identified 281 orchid species (18 of them are endemics), which are mainly distributed in tropical and subtropical regions of northern of the country (Schinini 2008; Zuloaga and Belgrano 2015). The highest diversity of orchid species has been found in Misiones (129 species) and Corrientes (76 species) (Zuloaga et al. 1999). To date, there are no records of extinct orchid species for Argentina; however, 14 species are threatened or in danger of extinction according to the database of plants from Argentina PlanEAr (http://www.lista-planear.org). Likewise, many orchid species have ornamental value both for their colourful flowers and their vegetative aspect. These species are subject to extractive action by local people, reason why they should be also considered for their conservation.

In the last twenty years great progress has been made by the IBONE (Corrientes, Argentina) staff towards the development of efficient in vitro propagation and germplasm conservation systems for several wild orchids from Argentina. Some of these studies are presenting below to illustrate the development of these biotechnological approaches in the IBONE. 


\section{Epiphytic orchids}

\section{Genus: Cattleya}

The genus Cattleya Lindl. (Subfamily Epidendroideae, Tribe Epidendreae, Subtribe Laeliinae) is one of the largest in the family Orchidaceae. It is a Neotropical genus which comprises 114 species of outstanding horticultural importance (van den Berg 2005; 2008; 2014). Cattleya species occur mainly in two distinct regions, forests throughout the Brazilian east coast and in the lower part of the humid declivities of the Andean Mountains in Peru, Colombia, Ecuador, and Venezuela, reaching the south of Mexico. These species occupy predominantly epiphytic habitats and most of them show crassulacean acid metabolism (Andrade-Souza et al. 2009). They are of high ornamental value due to the size of their flowers and many species are used for hybridization (van den Berg and Martins 1998; van den Berg et al. 2000). Lately, new combinations and names were proposed in Cattleya to accommodate species previously assigned to Laelia and Sophronitis. These were needed in order to maintain the monophyly of the genus in light of recent phylogenetic hypotheses (van den Berg et al. 2000; 2009). In Argentina occur C. cernua, C. coccinea, C. loddigesii, and C. lundii.

Cattleya lundii (Rchb. F. \& Warm.) Van den Berg is native from Brazil, Bolivia, and Argentina, where it is at 740 to 1000 meters over the sea level between the undergrowth in the coastal mountains or in the Yungas forests. In Argentina, it was found in the province of Misiones, where it grows in flooded regions. It was also cited for the province of Salta (Johnson 2001). C. lundii includes epiphytic and lithophytic plants of medium size, with small pseudobulbs that bear two leaves $(9-15 \mathrm{~cm}$ long). It blooms during the winter and has individual flowers or 2-flowers inflorescences. Flowers $(38 \times 31 \mathrm{~mm})$ are fragrant, erect, resupinate, and pedicelled, with labellum trilobulate, stretched, fleshy, white with violet nerves and yellowish base (Johnson 2001). Their flowers remain open for 10-15 days and have good size as well as interesting colours from a commercial point of view, so they can serve as a source for crosses with other species to obtain plants with better appearance and more abundant flowering (Cardoso 2014; Cardoso and Israel 2005).

In the last years, staff of the IBONE has conducted studies aimed at developing efficient plant propagation systems for $C$. lundii through in vitro seed germination (unpublished data). Results from these researches are briefly presenting below.

1- Seed germination: Fruits (capsules) of 6 to 9 months after hand-pollination were used for this study, which were surface sterilized and seeds were aseptically removed. A total of 24 culture media were assessed, which were constituted by full- or half-strength MS, EFp (modified MS according to Eduardo Flachsland, with changes in the macronutrient composition and supplemented with soy peptone), or Hyponex ${ }^{\circledR} 2$ g.L. (a commercial $^{-1}$ (a fertilizer formulation 6.5-6-19), alone or supplemented with of 25 g. $\mathrm{L}^{-1}$ green banana puree and/or $250 \mathrm{mg} . \mathrm{L}^{-1}$ activated charcoal. All media were supplemented with $3 \%$ sucrose. Cultures were incubated in a growth room at $27 \pm 2{ }^{\circ} \mathrm{C}$ with 14 -h light/10-h dark photoperiod (116 $\mu \mathrm{mol} . \mathrm{m}^{-2} . \mathrm{s}^{-1}$ PPFD).

Asymbiotic seed germination was significantly affected by the different fruit development stages assessed in this study. Seeds from 6- and 7-month-old capsules showed fast oxidation and subsequent death, without allowing plant regeneration. Seeds from 8- 
month-old fruits displayed high oxidation rate and very low germination percentages $(<10 \%)$, regardless of the culture media. On the other hand, seeds from 9-month-old capsules showed scarce oxidation and germinated in all the culture media evaluated with percentages varying between 25 and $65 \%$ according to the media composition. The onset of germination was observed 2 months after seeds sowing. Germinating seeds showed enlargement, change to green color, and development into protocorms. Germination percentage $(=$ seeds that developed protocorms) was determined 5 months after seed sowing. Full-strength MS, EFp and Hyponex ${ }^{\circledR}$ supplemented with both green banana puree and activated charcoal allowed the significantly highest germination percentages (55 to 65\%). These results demonstrate the promotory effect of the natural additives added to culture media on seed germination of $C$. lundii. A large number of complex additives like peptone, carrot juice, tomato juice, beef extract, potato extract, and especially coconut water, banana extract, etc. are commonly added to orchid media (Chen et al. 2015; Chugh et al. 2009; Vijayakumar et al. 2012). As early as the 1950s, Steward and Simmonds (1954) reported that substances stimulating cell divisions in carrot cells are present in the formative layers of banana fruit. Banana pulp is a rich source of natural cytokinins as well as auxin and gibberellins (Arditti and Ernst 1993; Khalifah 1966; Lahav and Gottreich 1984). On the other hand, addition of activated charcoal to the medium can help overcome inhibitory effects of phenolics released into the medium and have often been used in orchid media (Chugh et al. 2009). Activated charcoal seems to adsorb the toxic substances that may form in the medium as a result of autoclaving or be released by the explant. It may also stimulate rooting by absorbing the toxins and excluding light from the medium (Paek and Murthy 1977; Yam et al. 1989). Eymar et al. (2000) observed that the addition of activated charcoal increased and maintained $\mathrm{pH}$ levels during culture, increased the nitrogen uptake and improved growth and visual aspects of the explants and reduced the inhibitory effect of exogenous cytokinin on root growth. However, activated carbon is likely to interfere with other additives as well. Therefore, its use should be evaluated for each case.

2- Seedling growth: Protocorms were subsequently transferred to fresh media of the same composition to promote seedlings growth and well-developed plantlets formation, which is desirable for ex vitro acclimation. After additional 14 months of culture, protocorms developed into healthy plantlets with well-formed pseudobulbs, leaves, and roots in all the culture media evaluated. However, the number of shoots, pseudobulbs, leaves, and roots as well as the dry weight of shoots and roots were significantly affected by the media composition. Full-strength MS supplemented with activated charcoal allowed the significantly highest growth rate of seedling, displaying a mean number of 9 shoots, 5 pseudobulbs, 26 leaves, and 24 roots per plant, with a mean dry weight of $117 \mathrm{mg}$ and $103 \mathrm{mg}$ per plant for shoots and roots, respectively. Results from this assay corroborates that activated charcoal is useful for seedling growth of $C$. lundii. On the other hand, although promotory effect of banana extract on increase the seedling growth and root number was previously reported in other Cattleya species (Arditti 1968) as well as in other orchid genus (Lo et al. 2004; Vyas et al. 2009); results from this study demonstrated an inhibitory effect of banana puree added to the culture media on $C$. lundii seedling growth, contrarily what taken place during the germination phase.

Finally, after 28 months from the experiment establishment $(9$ months from handpollination to fruit maturation +5 months for seed germination +14 months for seedling growth), well-developed plantlets were transplanted to moss and tree bark in plastic pots and 
successfully transferred to a greenhouse for hardening. This protocol of plant regeneration by asymbiotic seed germination should permit massive propagation and conservation of this species with ornamental value.

\section{Genus: Cohniella}

The genus Cohniella Pfitzer (Subfamily Epidendroideae, Tribe Cymbidieae, Subtribe Oncidiinae) is a Neotropical genus of 13 species, which are known in horticulture as the "rattail oncidiums". The genus is distributed widely from northern Mexico into southern Brazil and northern Argentina, mostly in the lowlands. It is characterized by medium to large plants with inconspicuous to small pseudobulbs that bear a single, succulent, terete leaf (Carnevali et al. 2010). Two species were cited for Argentina: C. cepula and C. jonesiana.

- Cohniella cepula (Hoffmanns.) Carnevali and G. Romero was found in Argentina, Bolivia, Brazil, Paraguay, and Peru. In Argentina, it is known from the "Norte Grande" region, where it grows in riparian forests at 0-900 meters over the sea level. This species includes epiphytic erect herbs, shortly creeping to cespitose; with short, thin rhizome. It blooms from January to May (summer in the southern hemisphere) and has the smallest flowers of the genus (20-24 $\mathrm{mm}$ diameter), with yellow labellum, in racemose or paniculate inflorescences (with 6-26 flowers) longer than the leaves (Carnevali et al. 2010; Cetzal-Ix et al. 2012; Insaurralde and Radins 2007).

- Cohniella jonesiana (Rchb. f.) Christenson is known from Argentina, Bolivia, Brazil, and Paraguay. Most of the C. jonesiana collections are concentrated on the oriental portion of Paraguay, growing epiphytically in gallery forest along the Paraguay River. Similarly, it grows in the northeast portion of the province of Corrientes and Misiones in Argentina, bordering Paraguay. This species includes epiphytic pendent herbs, shortly creeping to cespitose; with short, thin rhizome. It is easily recognized from other Cohniella taxa by the combination of a large flower (43-60 mm diameter) with a white central lobe of the labellum that has red spots toward its base; in racemose inflorescences (with 2-10 flowers) which bloom during the summer, shorter than the leaves (Carnevali et al. 2010; Cetzal-Ix et al. 2012; Insaurralde and Radins 2007).

Both species have ornamental value and their natural populations are on decline due to their wild over-collection for marketing and widespread disturbance of their ecosystems. Consequently, it is imperative to develop effective propagation and ex situ preservation strategies for these orchids to safeguard the threatened diversity of the genus Cohniella, mainly due to the anthropogenic impact. In recent years, staff of the IBONE has made important advances on in vitro plant propagation and germplasm conservation of C. cepula and $C$. jonesiana. Results from these researches are briefly presenting below.

1- Seed germination: Asymbiotic seed germination of C. cepula and C. jonesiana was assessed with the aim of develop efficient propagation systems for these species (unpublished data). The effects of fruit maturity (12 to 14 weeks after hand-pollination for C. cepula and 19 to 22 weeks after hand-pollination for $C$. jonesiana), the nutritive media composition (full-, half- or quarter-strength MS medium with 3\% sucrose, alone or supplemented with $500 \mathrm{mg} . \mathrm{L}^{-}$

${ }^{1}$ soy peptone, banana powder and/or activated charcoal; assessing a total of 24 culture media) and light condition during culture incubation (14-h light/10-h dark photoperiod with 116 $\mu \mathrm{mol} . \mathrm{m}^{-2} . \mathrm{s}^{-1}$ PPFD or permanent darkness) on seed germination were evaluated. In all cases, 
fruits were surface sterilized and seeds aseptically removed previous to sowing on the different culture media.

The onset of germination was observed 15-20 days after seeds sowing. Germinating seeds showed enlargement, change to green/white color, and development into protocorms. Germination percentage ( $=$ seeds that developed protocorms) was determined 8 weeks after sowing. Seeds of both species germinated in all evaluated conditions; however, the germination percentage was significantly affected by the nutritive media composition and light condition during the incubation. The highest germination percentages were obtained on full-strength MS alone or supplemented with activated charcoal ( $\sim 80 \%$ seed germination for C. cepula) and full-strength MS supplemented with soy peptone alone or combined with activated charcoal and/or banana powder (60-65\% seed germination for C. jonesiana), and incubating the cultures under 14-h light/10-h dark photoperiod (Figure 1). These results demonstrate again the promotory effect of the natural additives added to culture media (such as activated charcoal and soy peptone) on seed germination of orchid species. The potential effects of activated charcoal were discussed above. Regarding to peptone, its promotory effect may be due to peptone contains amino acid, protein (Nhut et al. 2008) and vitamin: biotin, pyridoxine, thiamin and nitrogen (Arditti 1992), and can increase the growth and the development of explants (Dutra et al. 2008). Result from this study is in agreement with Hossain and Dey (2013) who reported that MS, Phytamax, and P723 media containing peptone supported the seed germination in Spathoglotis plicata better than devoid of peptone. Likewise, the supplementation of peptone in Knudson C and VW basal media promoted seed germination and seedling development in Vanda belvola (David et al. 2015) and D. lasianthera (Wida Utami et al. 2017) respectively.
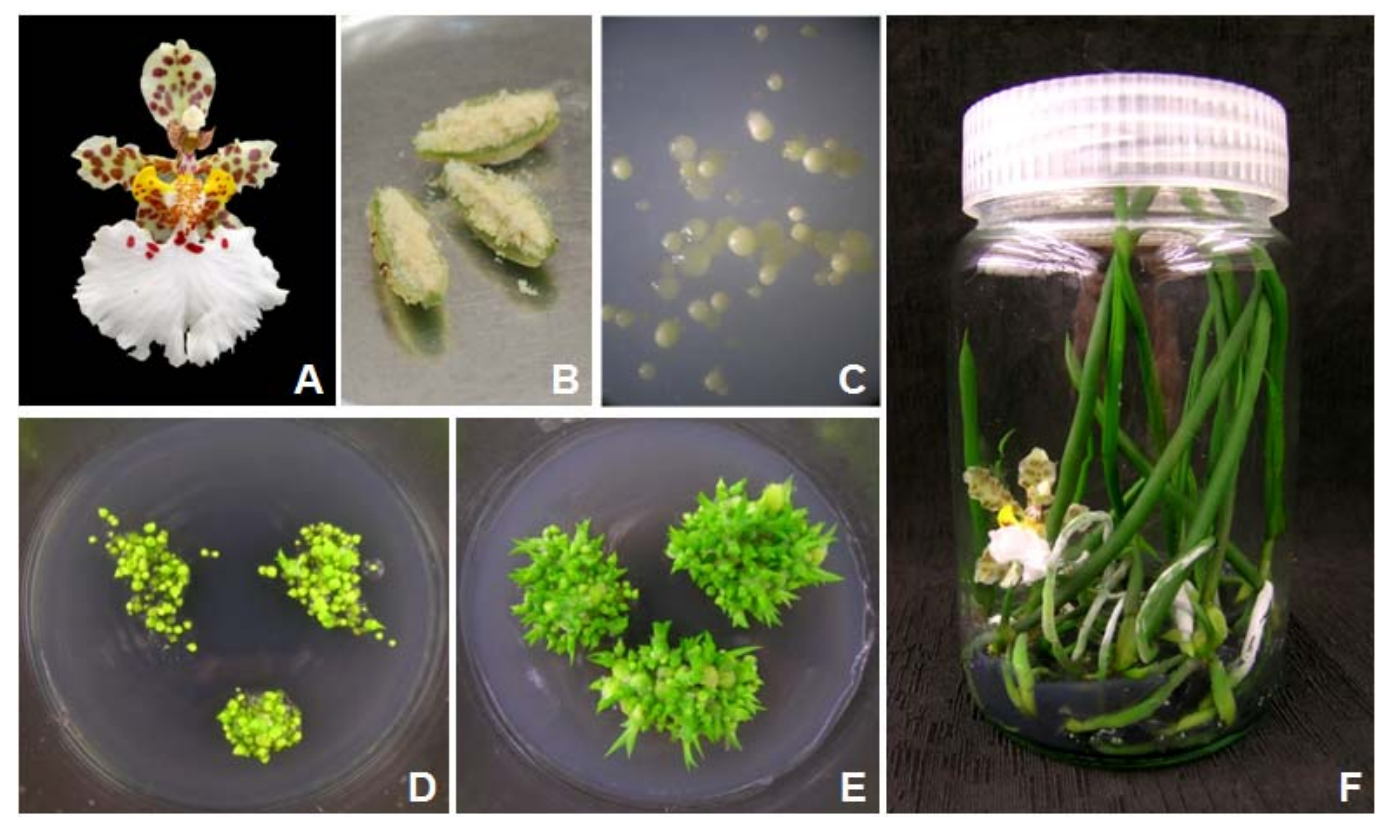

Figure 1 Cohniella jonesiana plant propagation through asymbiotic seed germination. (A) Flower from the working collection maintained in the greenhouse. (B) Fruit at 22 weeks after hand-pollination aseptically opened for removing seed samples. (C-E) Protocorms and plantlets obtained by asymbiotic germination 75 days after seed sowing on MS supplemented with activated charcoal $(\mathbf{C}, \mathbf{D})$ and soy peptone $(\mathbf{E})$, and incubating the cultures in permanent darkness (C) or under 14-h light/10-h dark photoperiod (D, E). (F) In vitro plants of $C$. jonesiana in suitable conditions to be transferred to a greenhouse for hardening. 
It is worth mentioning that seed germination was not significantly affected by the different fruit development stages assessed in this study, demonstrating that seeds from all fruits of both species were properly developed at the moment of fruit collection. Seeds from immature capsules are suitable for in vitro germination as embryos become viable and develop normally prior to the capsule ripening; which makes possible their easy surfacesterilization (Arditii 1967; Mitchell 1989; Yam and Weatherhead 1988). Also, stringent surface-sterilization of seeds after fruit dehiscence may affect their viability and reduce the germination percentage in orchids (Van Waes and Debergh 1986).

Protocorms developed leaf primordia and rhizoids, and successfully developed into seedlings, which then showed well-formed leaves and roots. Seedlings transferred to the same medium devoid of any plant growth regulator displayed continuous growth and after 22 to 26 weeks of the seed sowing whole plantlets $(6-10 \mathrm{~cm}$ long) were developed, which were successfully transferred to pots and acclimatized to greenhouse conditions. Plants attained maturity and developed normal flowers and capsules after about two years of the culture establishment. This protocol of successful plant regeneration by asymbiotic seed germination should permit rapid propagation and conservation of these threatened Cohniella species with ornamental value.

2- Direct embryogenesis from somatic explants: Somatic embryogenesis from vegetative explants was assessed aimed to develop an effective tissue culture system for clonal propagation of $C$. cepula and $C$. jonesiana (unpublished data). In vitro plants of both species grown on MS devoid of plant growth regulator and incubated under a 14-h light/10-h dark photoperiod (116 $\mu \mathrm{mol} . \mathrm{m}^{-2} . \mathrm{s}^{-1}$ PPFD) were used in this experiment. The effects of six types of explants (basal, middle, and apical segments of young leaves and roots), combinations and concentrations of six plant growth regulators [cytokinins: N6-benzylaminopurine (BAP), thidiazuron (TDZ), kinetin (KIN); auxins: naphthalene acetic acid (NAA), indole-3 butyric acid (IBA), 2,4-dichlorophenoxyacetic acid (2,4-D)] and light condition during culture incubation (14-h light/10-h dark photoperiod or permanent darkness) on direct embryogenesis were studied.

After 60 days of culture, basal segment of young leaves were the only explants that showed PLBs formation in all the conditions assayed. However, embryogenesis was significantly affected by the culture media and light condition during incubation. KIN, BAP or TDZ (3 mg. $\left.\mathrm{L}^{-1}\right)$ alone or combined with either IBA or 2,4-D $\left(0.1 \mathrm{mg} . \mathrm{L}^{-1}\right)$ and incubation on permanent darkness provided the highest percentages of PLBs induction (80 to $95 \%$ ). After transference of PLBs to fresh MS devoid of any plant growth regulator, they developed leaf primordia and rhizoids and successfully grown into plantlets with normal vegetative morphology (Figure 2). The highest percentages of plant regeneration were obtained from leaf explants induced with KIN or BAP $\left(3 \mathrm{mg} \mathrm{L}^{-1}\right)$ alone or combined with IBA $\left(0.1 \mathrm{mg} . \mathrm{L}^{-1}\right)$. It was previously reported that TDZ is more effective than other cytokinins (the adenine-type cytokinins like BAP and KIN) in inducing shoot bud differentiation from various explants (Ernst 1994; Nayak et al. 1997a,b). However, the drawback of using TDZ in regeneration studies includes difficulty in elongation and rooting of regenerated shoots. This may be due to the high cytokinin activity and persistence of TDZ in the tissue compared to adenine-type cytokinins (Huetteman and Preece 1993). Nayak et al. (1997a,b) overcame the problem of shoot elongation in Acampe praemorsa, Cymbidium aloifolium, Dendrobium aphyllum and Dendrobium moschatum by incorporating an auxin (NAA) at lower concentrations along with 
TDZ or by transferring the shoot clumps to a medium containing different phytohormones (BAP and NAA). Results from this research showed that incorporation of auxins (NAA, IBA or 2,4-D) in combination with TDZ was not efficient for shoot elongation even after 60 days of transference to MS devoid of plant growth regulator. Therefore, the adenine-type cytokinins alone or combined with low concentration of IBA were more competent for plant regeneration of $C$. cepula and $C$. jonesiana from pieces of young leaves. Regenerated plantlets were successfully transferred to pots and acclimatized to a greenhouse conditions. Thus, these results offer efficient means for mass clonal propagation of these and possibly other related Cohniella species.
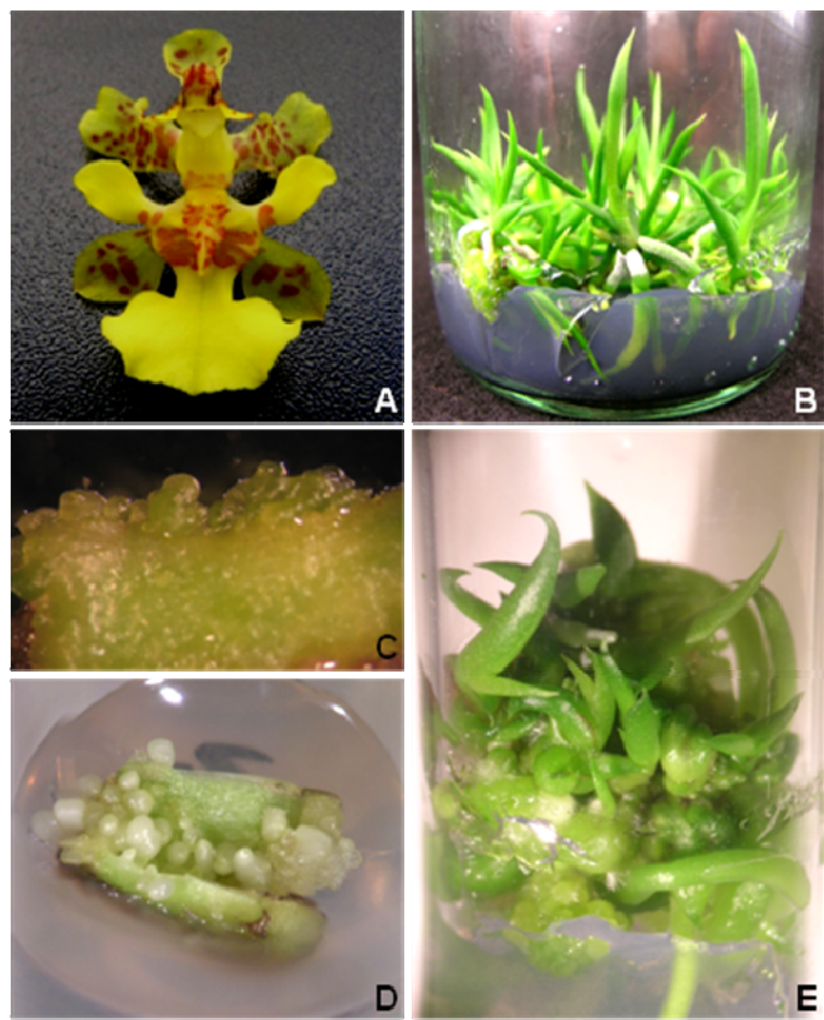

Figure 2 Cohniella cepula plant regeneration through somatic embryogenesis. (A) Flower from the working collection maintained in the greenhouse. (B) In vitro plants of C. cepula grown on MS devoid of plant growth regulator, used as a sourse of explants in somatic embryogenesis experiment. (C, D) Development of PLBs from basal segments of young leaves after 30 (C) and 60 (D) days induction on MS supplemented with $3 \mathrm{mg} \mathrm{L}^{-1} \mathrm{KIN}$. (E) Plantlets obtained 60 days after transference of PLBs to MS devoid of plant growth regulator.

3- Pollinia storage: The behaviour of C. cepula pollinia (without any preconditioning) stored at different temperatures was examined, as a mean for preservation of haploid gene pool of its genetic resources (Dolce et al. 2016). Pollinia were collected from 1-day opened flowers of $C$. cepula and immediately transferred to cryovials and stored at four temperatures: $+4{ }^{\circ} \mathrm{C}$ (refrigerator), $-20{ }^{\circ} \mathrm{C}$ (conventional freezer), $-70{ }^{\circ} \mathrm{C}$ (ultra freezer), and $-196{ }^{\circ} \mathrm{C}$ (by direct immersion in LN). Pollen viability was evaluated through the fertilizing ability of fresh and stored (30 to 360 days) pollinia, which was determined by the fruit formation for each treatment as well as by the seed viability and in vitro seed germination. Results from this study revealed to C. cepula pollinia have "partially dehydrated pollen" ( 12\% MC) at anthesis, suggesting that this orchid pollen would be not recalcitrant. Regarding the storage 
assay, when pollinia were stored at +4 or $-20^{\circ} \mathrm{C}$ their longevity was reduced (60 to 120 days). This indicates that deleterious physical and chemical changes proceed gradually in refrigerator-stored pollen and they are not fully detained by the colder temperature attained in a conventional freezer. On the other hand, pollinia stored at -70 and $-196{ }^{\circ} \mathrm{C}$ showed high fertilizing ability (94\% to $100 \%$ ) even 1 year after collection, revealing no significant differences with fresh pollinia. Additionally, seeds showed high viability (91 to 94\%) through the 2,3,5-triphenyltetrazolium chloride (TTC) reduction assay and high germination percentages (92 to 97\%). No significant differences were found when seed viability and germination from all treatments (flowers pollinated with fresh and stored pollinia) were compared.

It is interesting to consider here that ultralow storage of pollinia was feasible without any desiccation, cryoprotection, or precooling treatment before placing into an ultra freezer (-70 ${ }^{\circ} \mathrm{C}$ ) or immersing in $\mathrm{LN}\left(-196^{\circ} \mathrm{C}\right)$. This is probably due to the low initial MC shown in the fresh pollinia for this species. Moreover, into the highly organized waxy pollinia the pollen is tightly packed in the pollen sac and embedded in a highly viscous fluid, i.e., elastoviscin (Pacini and Hesse 2002). The pollen cytoplasm and elastoviscin in pollinia are assumed to contain sucrose or other chemicals enough to protect the pollen from freezing injury. Sucrose allows pollen to be stored at low temperatures by protecting membrane integrity and through intracellular glass formation, thus preventing the formation of ice crystals (Firon et al. 2012; Speranza et al. 1997). It is assumed that the formation of highly viscous intracellular glasses decreases molecular mobility and impedes diffusion within the cytoplasm, thus slowing the deleterious reactions (Firon et al. 2012). Increased viscosity contributed by solutes concentrated in cells inhibits the coming together of water molecules to form ice, and is described as the mechanism of glass transition (Benson 2008).

Results from this study showed that successful ultracold storage of $C$. cepula pollinia is feasible without any desiccation, cryoprotection, or precooling treatment before placing them into an ultra freezer $\left(-70^{\circ} \mathrm{C}\right)$ or immersing in $\mathrm{LN}\left(-196^{\circ} \mathrm{C}\right)$. Both fresh and stored pollinia of C. cepula allowed successful crosses generating fruits and viable seeds which germinated and developed into healthy and normal seedlings. Additional work in our laboratory proved the possibility of extending this ultracold storage procedure to other wild relative species such as C. jonesiana and Gomesa bifolia. Such information allows better planning of controlled breeding programs and the potential production of more diverse crosses.

4- Seed storage: The behaviour of C. cepula and C. jonesiana seeds removed from fruits at different ripening stage (next to date of their natural dehiscence) and maintained at different temperatures was examined (Dolce and González-Arnao 2018), since there was no antecedent reporting about seed conservation of Cohniella species. Fruits were collected at 12 to 14 weeks after hand-pollination for C. cepula and 19 to 22 weeks after hand-pollination for $C$. jonesiana. Immediately after collection, fruits were surface sterilized and seeds were aseptically removed. Seed samples from fruits at each ripening stage were transferred to cryovials and stored (up to 36 months) at four temperatures: $+27{ }^{\circ} \mathrm{C}$ (growth room), $+4{ }^{\circ} \mathrm{C}$ (refrigerator), $-20{ }^{\circ} \mathrm{C}$ (conventional freezer), and $-196{ }^{\circ} \mathrm{C}$ (by direct immersion in $\mathrm{LN}$ ). Moisture content (MC) and in vitro germination were determined for fresh seeds from each fruits.

The MC of seeds from fruits at the different ripening stage ranged between 5-12\%. Seeds from all fruits stored at $-196{ }^{\circ} \mathrm{C}$ showed high germinability $(\sim 90 \%)$ even 36 months after 
collection, revealing no significant differences with fresh seed germination. This result agrees with those reported in the literature, since high post-cryopreservation germination has been achieved in most studies suggesting that the majority of orchid seeds at less than ca. $13 \% \mathrm{MC}$ can be successfully cryopreserved by the simple method of direct cryopreservation (Popova et al. 2016). On the other hand, seeds stored at $-20^{\circ} \mathrm{C}$ remained high germinability $(\sim 60 \%)$ after 12 months, but germination markedly decreased to $10-20 \%$ after 18 months and fell to $0 \%$ on 24 months after storage. Likewise, seed germination of Coelogyne foerstermannii Rchb.f., $C$. rumphii Lindl. and Dendrobium stratiotes Rchb.f. fell to $1-5 \%$ from initial values of $65-96 \%$ after equilibrated to $15 \% \mathrm{RH}$ and stored at $-20^{\circ} \mathrm{C}$ for $9-12$ months. In contrast, Xylobium undulatum (Ruiz \& Pav.) Rolfe seeds lost only 13\% germinability during the same interval (Seaton et al. 2013). Based on these responses, we can conclude that orchid seeds conservation is a relatively underdeveloped area that demands further research. For the time being, seed storage at temperatures above freezing or under conventional banking conditions $\left(-18^{\circ} \mathrm{C}\right.$ and $\left.5 \% \mathrm{MC}\right)$ does not get an acceptable result in keeping high viability of certain orchids for long period (Chang et al. 2006; Hay et al. 2010; Hirano et al. 2009, Pritchard and Dickie 2003). This fact has reinforced the need to investigate the cryostorage behaviour of orchid seeds (Merritt et al. 2014; Pritchard et al. 1999) as well as the seeds of other species (Li and Pritchard 2009). Finally, when seeds were stored at +27 and $+4^{\circ} \mathrm{C}$, germination rapidly decreased to $0 \%$ within 1-6 months storage. These results agree with those reported by other authors (Koopowitz and Thornhill 1994; Pritchard and Seaton 1993; Pritchard et al. 1999), who informed that orchid seeds stored under room temperature and warm conditions (e.g. $20-40^{\circ} \mathrm{C}$ ) may lose viability in weeks or days.

Results from this research shown that the key factor to extend the longevity of C. cepula and C. jonesiana seeds is the storage temperature. Only those seeds maintained at $-196{ }^{\circ} \mathrm{C}$ retained germination percentages similar to fresh seeds, even after being stored for three years. Thus, the establishment of cryobanks present great potential for long-term storage of seeds from these species. Further work will determine the applicability of this procedure to a wider range of Cohniella species, so that this approach could be used for the establishment of cryogenic collection of germplasm for different orchid species.

\section{Genus: Gomesa}

The genus Gomesa R. Br. (Subfamily Epidendroideae, Tribe Cymbidieae, Subtribe Oncidiinae) is a Neotropical genus with about 130 species (Govaerts 2018). The genus is distributed in tropical and subtropical regions from South America, with southern limit in northern Argentina and eastern Uruguay. It is characterized by small to large, generally epiphytic plants, with racemose or paniculate multifloral inflorescences (Valebella 2017).

Gomesa bifolia (Sims) M.W. Chase \& N.H. Williams, commonly called the duckling orchid, was found in Bolivia, Brazil, Paraguay, Uruguay, and Argentina in the warm lowlands in the shade along streams and in the coolest mountain forests from sea level to about 2000 m.a.s.l. Its southern limit of natural distribution is the riparian forests of the Río de la Plata, in the province of Buenos Aires (Argentina), which probably makes it the most austral epiphytic orchid on the planet (Cellini et al. 2009). It is a perennial epiphytic orchid that presents ovoid or ovoid-oblong pseudobulbs, deeply furrowed, with 1 or 2 apical oblong-linear and acuminate leaves. It has showy yellow flowers (20-30 x 40-55 mm diameter) with brown markings on sepals and petals, fragranceless and with oil as reward, in racemose or paniculate 
inflorescences (20-50 cm long, with 7-15 flowers). G. bifolia is a mainly self-incompatible, non-autogamous and pollinator-dependent species (Torretta et al. 2011). Traditionally, G. bifolia was considered within the genus Oncidium, one of the most conspicuous and systematically controversial genera of Neotropical orchids. On the basis of molecular phylogenetic studies, Chase et al. (2009) transferred O. bifolium Sims to the genus Gomesa R. $\mathrm{Br}$. with the purpose of redefining the taxonomic limits of Oncidium to a monophyletic group of species (Torretta et al. 2011; Valebella 2017).

In the last years, staff of the IBONE has conducted researches aimed at in vitro plant regeneration as well as at long-term preservation of $G$. bifolia germplasm. Results from these studies are briefly presenting below.

1- Seed germination: Asymbiotic germination of G. bifolia seeds was assessed aiming at developing an efficient propagation method for this species (unpublished data). The effect of fruit maturity (18 to 20 weeks after hand-pollination), the nutritive media composition (full-, half- or quarter-strength MS medium with 3\% sucrose, alone or supplemented with $500 \mathrm{mg}$. $\mathrm{L}^{-}$ ${ }^{1}$ soy peptone, banana powder and/or activated charcoal; assessing a total of 24 culture media) and light condition during culture incubation (14-h light/10-h dark photoperiod with 116 $\mu$ mol. $\mathrm{m}^{-2} . \mathrm{s}^{-1}$ PPFD or permanent darkness) on seed germination was evaluated.

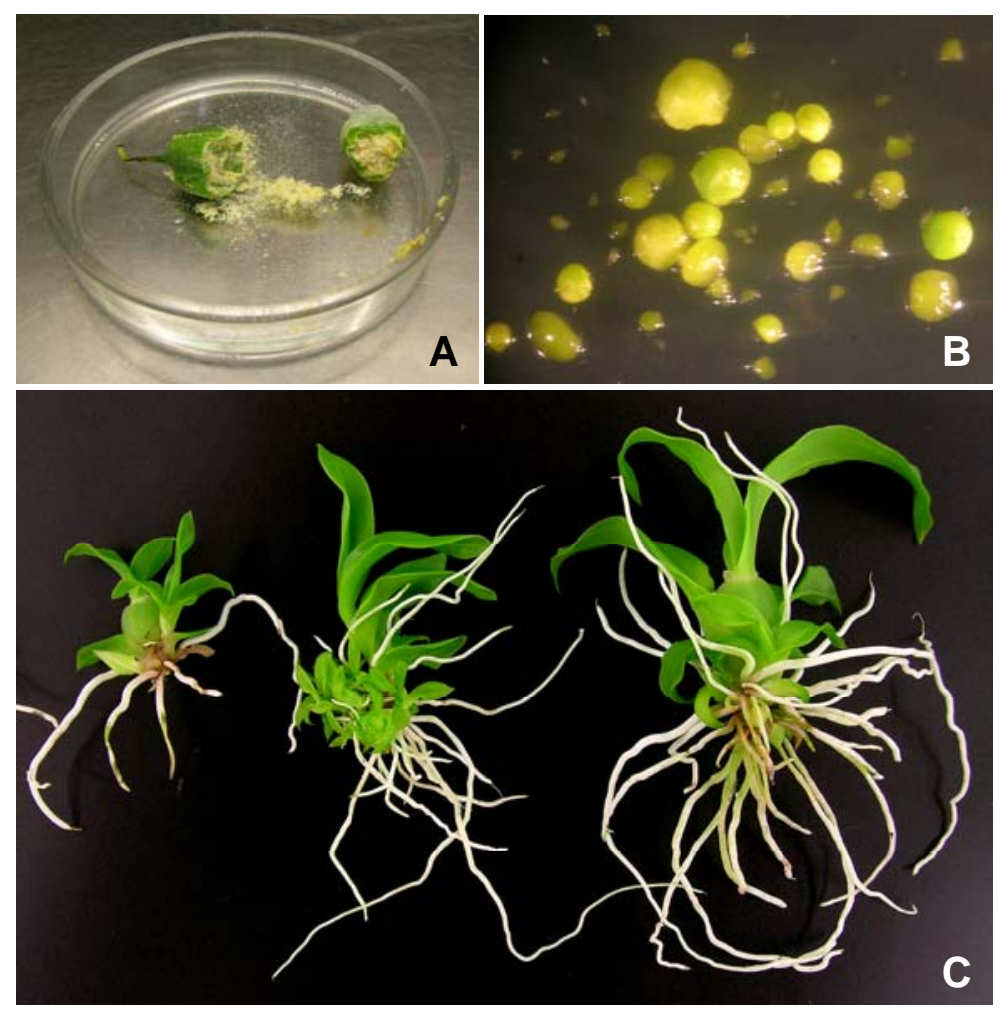

Figure 3 Gomesa bifolia plant propagation through asymbiotic seed germination. (A) Fruit at 19 weeks after hand-pollination aseptically opened for removing seed samples using for germination experiments. (B) Protocorms obtained by asymbiotic germination 60 days after seed sowing on MS supplemented with soy peptone and activated charcoal. (C) Plantlets obtained after 6-7 months from the seeds sowing, which have suitable conditions to be transferred to a greenhouse for hardening. 
The onset of germination was observed 15-20 days after seeds sowing. Germinating seeds showed enlargement, change to green/white color, and development into protocorms. Germination percentage ( $=$ seeds that developed protocorms) was determined 8 weeks after sowing. Seed germination taken place in all the conditions tested; however, the germination percentage was significantly affected by the nutritive media composition and light condition during the incubation. The highest germination percentage $(82 \%)$ was obtained on halfstrength MS supplemented with soy peptone and incubating the cultures under 14-h light/10-h dark photoperiod. Here again, as occurred with $C$. jonesiana, it was demonstrated the promotory effect of soy peptone added to culture media on seed germination of orchid species.

On the other hand, as was observed with C. cepula and C. jonesiana, seed germination was not affected by the different fruit development stages assessed in this study, indicating that seed were adequately developed at the moment of fruit collection. Protocorms developed leaf primordia and rhizoids, and successfully developed into seedlings, which then showed well-formed leaves and roots. Seedlings transferred to the same medium devoid of any plant growth regulator showed continuous growth and after additional 14 to 18 weeks, whole plantlets with conspicuous pseudobulbs and normal vegetative morphology were developed (Figure 3), which were successfully transferred to pots and acclimatized to greenhouse conditions. This successful plant regeneration protocol through asymbiotic seed germination allows rapid propagation and conservation of this orchid species with ornamental value.

2- Seed and protocorm cryopreservation: The first report for germplasm preservation of $G$. bifolia (Flachsland et al. 2006) was performed with seeds and protocorms following the encapsulation-dehidration technique. Fresh seeds from green capsules (120 days after handpollination) and protocorms (derived from seeds germinated on liquid half-strength MS with $3 \%$ sucrose after 60 days of culture) were used in this esperiment. Both seeds and protocorms were encapsulated in $3 \%$ sodium alginate polymerized with calcium chloride $\left(\mathrm{CaCl}_{2}\right)$ at 0.1 M. Encapsulated seeds were then pre-treated in liquid half-strength MS enriched with a progressively increasing sucrose concentration, using the following sequence: $0.15 \mathrm{M}(24 \mathrm{~h})$; $0.25 \mathrm{M}(48 \mathrm{~h}) ; 0.5 \mathrm{M}(24 \mathrm{~h})$ and $0.75 \mathrm{M}(24 \mathrm{~h})$. Pre-treatment was performed by placing samples at $27{ }^{\circ} \mathrm{C}$ on an orbital shaker at $80 \mathrm{rpm}$. After pre-treatment, the beads were surfacedried on filter paper and dehydrated using silica gel. Encapsulated seeds were dehydrated for 0 to $6 \mathrm{~h}$ while encapsulated protocorms were dehydrated for 0 to $10 \mathrm{~h}$. Samples were then placed into cryotubes and rapidly immersed in LN. After $1 \mathrm{~h}$ cryostorage, samples were rewarmed by immersing the cryotubes in a water-bath at $30{ }^{\circ} \mathrm{C}$ for $2 \mathrm{~min}$. Encapsulated seeds and protocorms were then pos-treated in liquid half-strength MS enriched with a progressively decreasing sucrose concentration: $0.75 \mathrm{M}(24 \mathrm{~h}) ; 0.5 \mathrm{M}(24 \mathrm{~h}) ; 0.25 \mathrm{M}(48 \mathrm{~h})$; and $0.15 \mathrm{M}(24 \mathrm{~h})$. The beads were then transferred to liquid half-strength MS with $3 \%$ sucrose for recovery. Survival was evaluated at various periods: after 30 days, by counting the number of seeds that turned green; after 90 days, by counting the number of seeds which formed protocorms; and after 180 days, by counting the number of protocorms that developed into plantlets.

For encapsulated seeds, bead MC varied from an initial 72\% to $13 \%$ (fresh weight basis) after $6 \mathrm{~h}$ dehydration. Survival of control seeds (-LN) was not affected by dehydration and remained above $88 \%$ in all cases. After cooling $(+\mathrm{LN})$, seed survival was nil for up to $2 \mathrm{~h}$ dehydration; it increased progressively to reach $89 \%$ after $5 \mathrm{~h}(19 \%$ bead MC) and decreased 
again to $67 \%$ after $6 \mathrm{~h}(13 \%$ bead MC). However, despite the high survival after $5 \mathrm{~h}$ dehydration, the percentage of protocorm development was only 5\%. For encapsulated protocorms, bead MC varied from $83 \%$ to $6 \%$ after $10 \mathrm{~h}$ desiccation. Survival of dehydration controls remained high $( \pm 80 \%)$ up to $7 \mathrm{~h}$ dehydration and then dropped rapidly to reach $20 \%$ after $10 \mathrm{~h}$ dehydration. Survival of cryopreserved protocorms was nil for 0 to $3 \mathrm{~h}$ dehydration and it increased progressively afterwards to reach $80 \%$ after 7 h dehydration ( $21 \%$ bead MC). Thereafter, survival decreased progressively and reached $0 \%$ after $10 \mathrm{~h}$ dehydration. Regarding to the plantlets formation, when encapsulated protocorms were pre-treated with progressively increasing sucrose concentration and then dehydrated for $7 \mathrm{~h}, 11 \%$ of the cryostored protocorms were able to continue growth and developed into whole plants with normal vegetative morphology.

Although it is necessary to optimize the plant regeneration through cryopreserved seeds and protocorms, this research describes for the first time the recovery of whole plants after cryopreservation of $G$. bifolia seeds and protocorms following the encapsulation-dehydration technique. This cryogenic procedure does not require any special equipment and is simpler than other vitrification techniques with the material studied, i.e. minute explants. This report also opens up the possibility of recovering plants from cryopreserved seeds and protocorms of other Gomesa species.

More recently, the possibility of storing G. bifolia seeds (without any preconditioning) was examined (unpublished data). Fruits were collected at 19 weeks after hand-pollination. Immediately after collection, fruits were surface sterilized and seeds were aseptically removed. Seed samples were transferred to cryovials and stored (up to 36 months) at four temperatures: $+27{ }^{\circ} \mathrm{C}$ (growth room), $+4{ }^{\circ} \mathrm{C}$ (refrigerator), $-20{ }^{\circ} \mathrm{C}$ (conventional freezer), and $-196{ }^{\circ} \mathrm{C}$ (by direct immersion in LN). Moisture content (MC) and in vitro germination were determined for fresh seeds.

Fresh seeds showed $\sim 5 \% \mathrm{MC}$ and high germination percentages $(\sim 90 \%)$. Seeds stored at $-196{ }^{\circ} \mathrm{C}$ displayed high germinability $(\sim 90 \%)$ even 36 months after collection, revealing no significant differences with fresh seed germination. On the other hand, seeds stored at $-20{ }^{\circ} \mathrm{C}$ maintained high germinability $(\sim 65 \%)$ after 12 months, but germination fell to $0 \%$ after 24 months storage. Finally, when seeds were stored at +27 and $+4^{\circ} \mathrm{C}$, germination rapidly decreased to 0\% within 1-6 months storage. As was observed for C. cepula and C. jonesiana, this research shown that $G$. bifolia seeds may be stored without any preconditioning if they are removed from mature fruits with low MC. Moreover, the key factor to extend the longevity of G. bifolia seeds is the storage temperature. Only those seeds maintained at -196 ${ }^{\circ} \mathrm{C}$ retained germination percentages similar to fresh seeds, even after being stored for three years. Thus, the establishment of cryobanks presents great potential for long-term storage of seeds from this species.

\section{Terrestrial orchids}

\section{Genus: $A a$}

The genus Aa (Subfamily Orchidoideae, Tribe Cranichideae, Subtribe Prescottiinae) has 25 described species endemic from mountain environments of South America. Five species were 
cited for Argentina: A. achalensis, A. fiebrigii, A. hieronymi, A. paludosa, and A. weddelliana (Schinini et al. 2008).

Aa achalensis Schltr. is $20-30 \mathrm{~cm}$ high and its small white flowers bloom in raceme from September to December (spring in the southern hemisphere). The habitats of this species include the Chaco Serrano woodlands and the highland grasses up to 3,000 $\mathrm{m}$ with relative low temperatures and rocky soils in West and Central Argentina (Bianco and Cantero 1985; Sérsic et al. 2006; Sobral and Fracchia 2010). A. achalensis was previously categorized as vulnerable and included in the red list of the International Union for Conservation of Nature (Vischi et al. 2004). However, new populations of this species were recently found in the slopes of the Velasco Mountains in the Province of La Rioja (Argentina), near $500 \mathrm{~km}$ from the previously known populations (Sobral and Fracchia 2010). Although these new findings require a modification in the conservation status of the species, the former and new populations are not included in a national protected area and are thus subjected to grazing, forest fires, illegal extractions, land conversions to agriculture, and the invasion of exotic species among others (Cagnolo et al. 2006; Marco and Páez 2000).

Since scarce information about the orchid mycorrhizal status in Argentina is available (Fracchia et al. 2008; Urcelay et al. 2005) and literature reporting successful symbiotic germination was absent, researchers from several scientific institutions from Argentina carried out a collaborative work with the aim of isolate root-associated fungi from the species A. achalensis and to determine their role in seed germination and protocorm development (Fracchia et al. 2014a). Results from this study are briefly presenting below.

1- Fungal isolation and culture: Healthy roots were detached from plants of A. achalensis at various developmental stages, which were collected from natural habitat. After their surfacesterilization, transversal root slices were transferred to potato dextrose agar (PDA) medium supplemented with antibiotics and incubated at $22{ }^{\circ} \mathrm{C}$ in the dark. They were observed periodically until fungal colonies were observed emerging from the root disks. Myceliums from these colonies were subcultured onto fresh PDA for purification. Purified fungal strains were stored at $5{ }^{\circ} \mathrm{C}$ and included with a strain number in the fungal collection at the Centro Regional de Investigaciones Científicas (La Rioja, Argentina).

2- Fungal morphological characterization: Fungal isolates were grown in PDA at $22{ }^{\circ} \mathrm{C}$ for $7-$ 21 days and colony colour and growth rate were measured. Replicates of each strain were left for at least 7 weeks to allow development of sclerotia and monilioid cells (Rhizoctonia-like) and sporulation (DSE, septate hyaline endophyte). The soil-agar method of Stretton et al. (1964) was used to induce teleomorph formation of Rhizoctonia-like isolates.

Pelotons and hyphal coils of Rhizoctonia-like mycorrhizal fungi were observed in all $A$. achalensis sampling individuals, with a mean percentage of $32 \%$. Melanized hyphae were also observed in root samples from all individuals (9\%). These fungi colonized the first cells layers of the root parenchyma without any necrotic tissue symptom. Globose to subglobose microsclerotia were detected in $40 \%$ of the sampled individuals. Five endophytic fungal isolates (two DSE, two Rhizoctonia-like, one septate hyaline endophyte) were recovered from the roots: $\mathrm{CC} 8, \mathrm{CC} 10, \mathrm{CC} 26, \mathrm{CC} 28$, and $\mathrm{CC} 29$. However, the colonial appearances, morphological features, and growth rates of isolates were ineffective at allowing us to determine the taxonomic identity of any fungal strains. No sporulation or teleomorphic stages 
were observed. Sclerotial masses were developed in both Rhizoctonia-like fungi and septate hyaline endophyte.

3- Fungal molecular characterization: Total genomic DNA was extracted and used as template for the PCR amplification of the intergenic spacer region from the nuclear ribosomal DNA (ITS hereafter). Amplification and sequencing were carried out using the primers ITS4 and ITS5 (White et al. 1990). All sequences were submitted to a BLAST search (http://blast.ncbi.nlm.nih.gov/Blast.cgi). Alignments were performed using MAFFT program version 6 (Katoh and Toh 2008) available on line (http://mafft.cbrc.jp/alignment/server/). Phylogenetic analyses were performed to assign isolates to a specific fungal group using ITS representative sequences available in GenBank. Sequences with at least $97 \%$ similarity were chosen. Isolates BLAST analyses revealed that the sequences from isolates CC8 and CC10 were similar (99\%) to Gaeumannomyces cylindrica/Phialophora graminicola. Isolate CC26 resulted similar (98\%) to uncultured Pezizaceae sequences. Isolates CC28 and CC29 were similar (98 and 99\%, respectively) to Thanatephorus cucumeris/Rhizoctonia solani.

4- Symbiotic seed germination: A. achalensis seeds were surface-sterilized and platted on oat meal agar medium. The plates were inoculated with a plug of each fungal inoculum taken from the hyphal edge after culturing on PDA. Uninoculated plates served as a control treatment. Seed germination and protocorm development were monitored weekly and scored on a scale of 0-5: 0) ungerminated seed, testa intact; 1) enlarged embryo, testa ruptured; 2) appearance of rhizoids (=germination); 3) appearance of protomeristem; 4) emergence of first leaf; 5) presence of second leaf (=seedling). Visualization of the mycobiont structures inside protocroms was evaluated at week 4, after staining them with Trypan Blue overnight and observed under the microscope. Moreover, seed viability was determined using the tetrazolium reduction assay (Singh, 1999).

The tetrazolium test revealed a viability of $43 \%$ for the harvesting A. achalensis seeds. Regarding to the seed germination, in all treatments the embryos swelled breaking the testa within 25 days after sowing. At 5 weeks, careful examination of protocorms after Trypan Blue staining revealed typical pelotons in the treatments inoculated with the Rhizoctonia-like fungi (strains CC28, CC29) and the sterile hyaline strain (CC26). The DSE fungi colonized the seeds with coiling hyphae inside the protocorm cells but no compact pelotons were observed. Total seed germination was significantly higher in all inoculated treatments, being both Rhizoctonia-like fungi (CC28, CC29) and the sterile hyaline strain (CC26) the most effective. In the asymbiotic treatment (control), the seeds swelled but we did not observe rhizoids along the assay.

Symbiotic orchid propagation had been previously achieved in some South American native species (epiphytes and terrestrial) from Colombia (Otero Ospina and Bayman 2009), Brazil (Pereira et al. 2005), and Chile (Steinfort et al. 2010). Nonetheless, there was no literature reporting symbiotic propagation assays for any Argentine species. Thereby, this wok was the first report of a successful in vitro symbiotic germination protocol for a native orchid species from Argentina. Data obtained from this study will help not only to the propagation and conservation of this species but also to collect information for future research on eight other terrestrial orchid species sympatric with A. achalensis in Central and West Argentina. Seedling acclimation, time required to further plant growth, and an evaluation of 
the survival rate in nature are the next steps towards a better knowledge of the species and to improve success in future conservation programs of this and other native orchid species.

\section{Genus: Cyrtopodium}

The genus Cyrtopodium (Subfamily Epidendroideae, Tribu Cymbidieae, Subtribu Cyrtopodiinae) is widely distributed in tropical and subtropical countries of Central and South America, which comprises about 30 species. It is representative from the central-west region of Brazil (Planalto Central) and extends throughout the South American continent reaching the north of Argentina (Menezes 2000). In Argentina, 5 species of Cyrtopodium are known: C. brandonianum, C. hatschbachii, C. palmifrons, C. pflanzii, and C. punctatum (Schinini et al. 2008).

- Cyrtopodium brandonianum Barb. Rodr. is a terrestrial orchid that was cited for Argentina, Bolivia, Brazil, and Uruguay. In Argentina, it grows spontaneously in sunny grasslands of Corrientes and Misiones (Sánchez 1986; Schinini et al. 2008). It has semiburied pseudobulbs that bear lanceolate leaves of about $30 \mathrm{~cm}$. Flowers $(3-3.5 \mathrm{~cm}$ in diameter) pinkish-brown with spots and a purple labelum, in racemose inflorescences (up to 15 flowers) which bloom in the new pseudobulbs in late spring or early summer. This orchid is popular among collectors due to its high ornamental value because of the beauty of its flowers (Menezes 2000), but its populations have decreased drastically over the last years due to the depredation of many populations as well as the destruction of their habitats.

- Cyrtopodium hatschbachii Pabst. is a terrestrial orchid which was discovered in Jataí, State of Goiás (Brazil) at $400 \mathrm{~m}$ over the sea level (Menezes 2000), reaching Northeastern Argentina and Paraguay. In Argentina it was found in the south of the province of Misiones (Sánchez and Varela 2012; Schinini et al. 2008). It grows spontaneously in some bathed and flooded, totally exposed to the sun. It has prolonged and fusifoms pseudobulbs (6-8 cm long). Their flowers $(3-3.5 \mathrm{~cm}$ in diameter) are reddish, pink or pinkish with a yellowish labelum, in racemose inflorescences (with 8-15 flowers) which bloom in late winter. The callus labelum is used to identify the species of this genus (Surenciski et al. 2012). Due to the restricted distribution of C. hatschbachii natural populations, its conservation acquires ecological significance. Our previous studies have demonstrated that immature seeds of this species exhibit a higher in vitro germination than the mature ones (unpublished date). Since immature seeds are kept under sterile conditions, they represent a suitable material for cryopreservation.

As mentioned above, it is imperative to develop effective propagation methods and ex situ preservation strategies for these orchids to safeguard the threatened diversity of the genus Cyrtopodium, mainly due to the anthropogenic impact. In recent years, staff of the IBONE has made important advances on in vitro plant regeneration and germplasm conservation of $C$. brandonianum and $C$. hatschbachii. Results from these researches are briefly presenting below.

1- Seed germination: Asymbiotic seed germination of C. brandonianum and C. hatschbachii was assessed with the aim of develop efficient propagation systems for these species (unpublished data). Fruits of 17 weeks after hand-pollination were used for this study, which were surface sterilized and seeds were aseptically removed (Figure 4). A total of 16 culture 
media were assessed, which were constituted by full- or half-strength MS or EFp, alone or supplemented with 25 g.L $\mathrm{L}^{-1}$ green banana puree and/or 2 g.L. $\mathrm{L}^{-1}$ activated charcoal. All media were supplemented with $3 \%$ sucrose. Cultures were incubated in a growth room at $27 \pm 2{ }^{\circ} \mathrm{C}$ with 14-h light/10-h dark photoperiod (116 $\mu \mathrm{mol} . \mathrm{m}^{-2} . \mathrm{s}^{-1}$ PPFD).

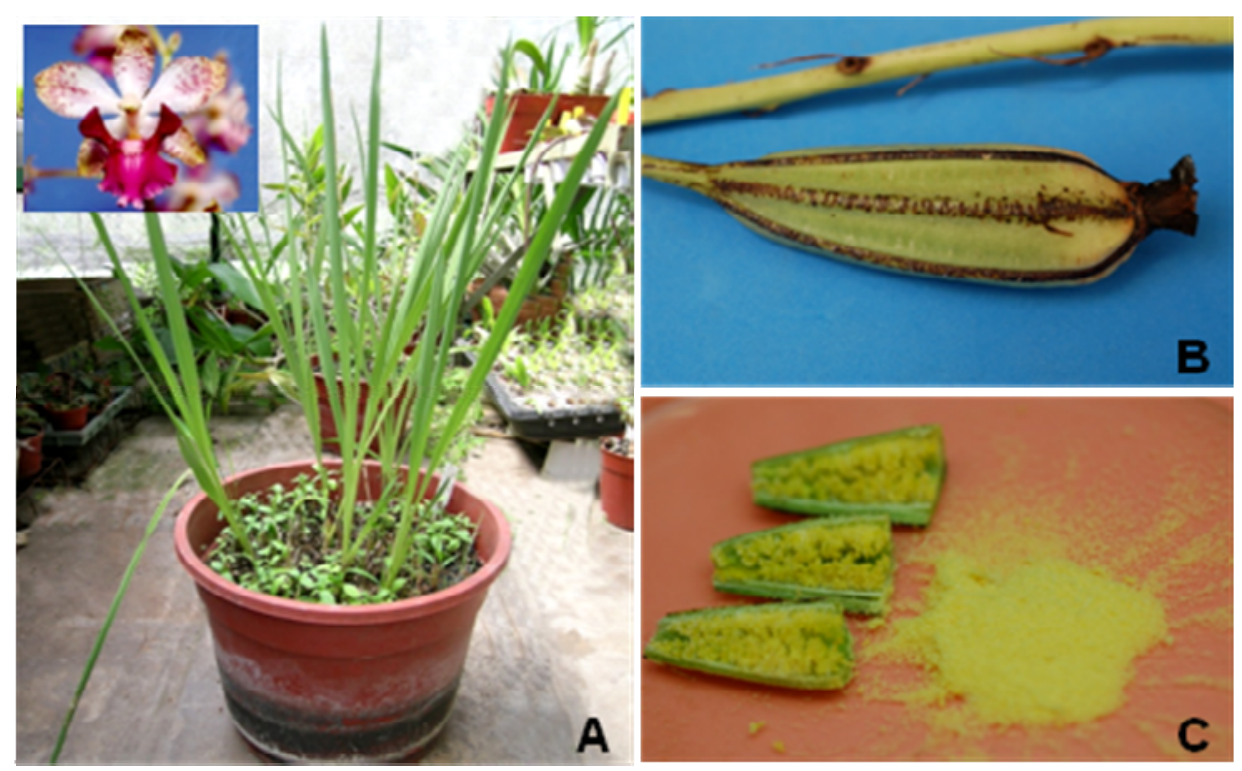

Figure 4 (A) Cyrtopodium brandonianum plants of the working collection maintained in the greenhouse; a detail of a flower is shown in the upper left. (B, C) Fruit at 17 weeks after hand-pollination aseptically opened for removing seed samples for asymbiotic germination experiments.

The onset of germination was observed 15-20 days after seeds sowing. Moreover, in some culture media, it was observed oxidation and subsequent death of $C$. brandonianum seeds. This fact specially occurred in the media lacking banana puree and activated charcoal. Germinating seeds showed enlargement, change to green color, and development into protocorms. Germination percentage ( $=$ seeds that developed protocorms) was determined 8 weeks after seed sowing. Asymbiotic seed germination occurred in all the culture media assessed in this study with percentages varying between 24 and $50 \%$ according to the media composition. Half-strength MS or EFp as wel as full-strength EFp supplemented with green banana puree and activated charcoal allowed the significantly highest germination percentages (47 to 50\%) for C. brandonianum, while half-strength MS supplemented with only activated charcoal allowed the highest germination percentage (49\%) for $C$. hatschbachii. These results demonstrate once again the promotory effect of the natural additives added to culture media (such as banana puree and activated charcoal) on seed germination of orchid species.

Protocorms developed leaf primordia and rhizoids, and successfully developed into seedlings. In the case of $C$. brandonianum, seedlings transferred to the same culture medium devoid of any plant growth regulator showed continuous growth and developed into whole plantlets with normal vegetative morphology. On the other hand, seedlings of $C$. hatschbachii were transferred to half-strength $\mathrm{MS}+2$ g. $\mathrm{L}^{-1}$ activated charcoal (basal medium) supplemented with 0.1 to $0.5 \mathrm{mg} . \mathrm{L}^{-1} \mathrm{NAA}$, IBA, or indole-3-aceticacid (IAA) alone or combined with $1 \mathrm{mg} . \mathrm{L}^{-1}$ BAP. Seedling developed into healthy plantlets with well-formed pseudobulbs, leaves, and roots in all the culture media evaluated. However, the number and 
length of leaves and roots as well as the dry weight per plant were significantly affected by the media composition. Basal medium supplemented with $0.5 \mathrm{mg} . \mathrm{L}^{-1} \mathrm{NAA}$ allowed the significantly highest growth rate of seedling.

In both species, 200 day-old in vitro regenerated plants were transplanted into a mixture of Sphagnum moss, peat and perlite $(1: 1: 1)$ in plastic containers for ex vitro acclimation. Ninety days after plants transference to ex vitro growth conditions, $60 \%$ of plants survived and showed normal vegetative morphology. This plant regeneration protocol by asymbiotic seed germination should permit rapid propagation and conservation of these threatened Cyrtopodium species with ornamental value.

2- Shoot regeneration from root explants: The use of root-tip culture for orchid propagation has attracted the attention of several researchers because it is a non-destructive technique in which the donor plants regenerate new roots in natural form. Also the availability of roots during the whole year makes them suitable explants for the in vitro cultivation (Kerbauy 1991; Park et al. 2003). In this work, a protocol for in vitro plant multiplication of $C$. brandonianum from root-tip culture was developed (Flachsland et al. 2011; Figure 5 and 6).

Root-tips isolated from in vitro plants of 150 days after germination and growth on halfstrength MS supplemented with green banana puree and activated charcoal were used as explants. The effect of the type [BAP, TDZ, KIN, 6-(4-hydroxy-3-methylbut-2enylamino)purine (ZEA), and N6-(2-isopentenyl)adenine (2iP)] and concentration (0, 0.1, 0.5 and $\left.1 \mathrm{mg} . \mathrm{L}^{-1}\right)$ of cytokinins added to half-strength MS medium on adventitious bud and shoot induction was evaluated. All cultures were incubated in a growth room at $27 \pm 2{ }^{\circ} \mathrm{C}$ with $14-\mathrm{h}$ light/10-h dark photoperiod (116 $\left.\mu \mathrm{mol} . \mathrm{m}^{-2} . \mathrm{s}^{-1} \mathrm{PPFD}\right)$.

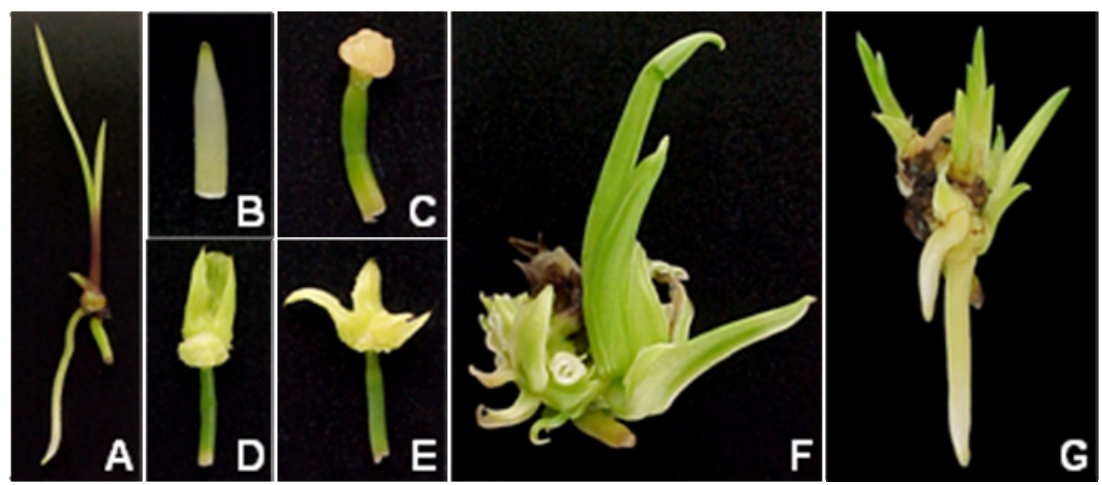

Figure 5 Cyrtopodium brandonianum plant regeneration from root-tips. (A) In vitro plant used as a sourse of explants. (B-F) Callus and adventitious bud and shoot differentiation from root-tips after 0 (B), 30 (C), 90 (D, E), and 150 (F) days induction on half-strength MS supplemented with $0.5 \mathrm{mg} . \mathrm{L}^{-1} \mathrm{TDZ}$. (G) Plantlets obtained 60 days after shoot transference to rooting medium.

After 30-45 of root-tips culture, the earliest visible signs of callus growth were noticeable. In some treatments, root tips gradually enlarged and small, compact, white yellowish or green calluses were observed. On longer incubation (60-70 days), adventitious bud and shoot differentiation taken place in 10 out of 16 variants of the medium investigated. Half-strength MS supplemented with $0.5 \mathrm{mg} . \mathrm{L}^{-1} \mathrm{TDZ}$ provided the highest percentages of shoot induction (43\%). On the contrary, there was no shoot regeneration when root-tips were cultured on media without any cytokinin or those containing KIN (any of the concentrations 
evaluated) as well as the lowest concentration of ZEA or the highest level of $2 \mathrm{iP}$ used in this study.

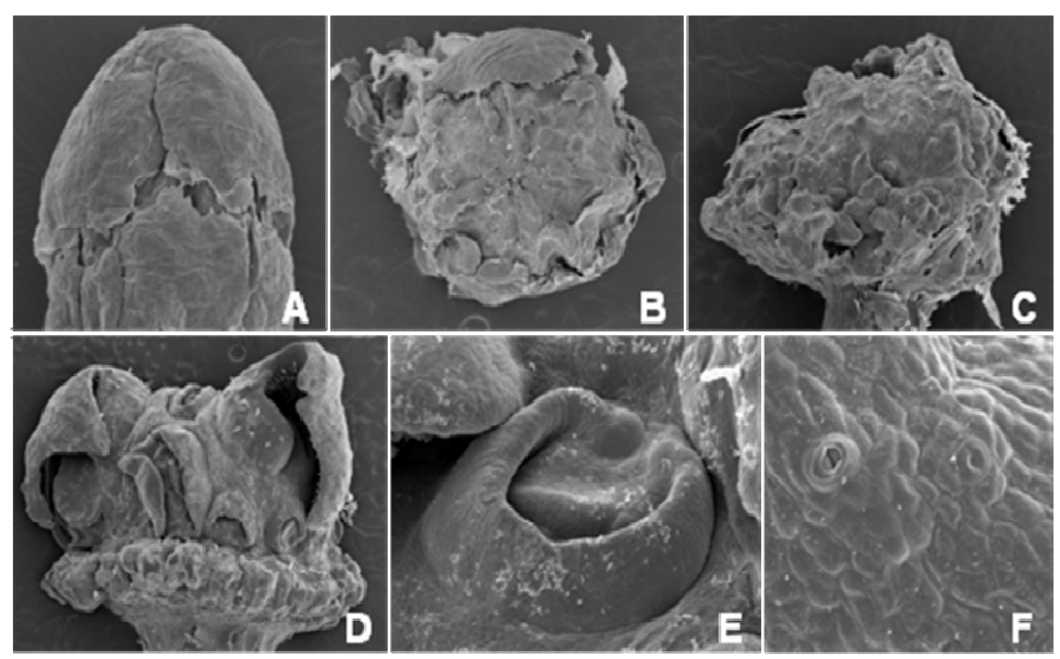

Figure 6 Photomicrographs of Cyrtopodium brandonianum plant regeneration from root-tips. (A-D) Callus and adventitious bud and shoot differentiation from root-tips after 0 (A), 30 (B), 60 (C), and 90 (D) days induction on half-strength MS supplemented with $0.5 \mathrm{mg} . \mathrm{L}^{-1} \mathrm{TDZ}$. (E) Detail of an adventitious bud. (F) Surface view of a leaf fragment with stomata.

The adventitious shoots were then transferred to half-strength MS with sucrose at 87.6, 175.2, and $262.8 \mathrm{mM}$ alone or supplemented with IBA, NAA, or IAA at 1 or $3 \mathrm{mg} . \mathrm{L}^{-1}$ for root induction. The percentage of shoots that formed roots and the mean number of roots per shoot varied significantly with the different concentrations of sucrose and auxins. The highest percentage of rooting $(\sim 30 \%)$ and the highest root number ( 4 roots per explants), with no intervening callus, was observed in half-strength MS supplemented with $6 \%$ sucrose and 1 mg. $L^{-1}$ NAA. Media without auxins did not promote root induction regardless of the sucrose concentration.

Results from this study demonstrate the potential of in vitro shoots regeneration from root tips of C. brandonianum. As was previously reported for species of Cattleya and Oncidium, this process taken place through indirect organogenesis (Kerbauy 1991; 1993). The requirements of exogenous plant growth regulators are similar to the ones of other orchid species in which shoot regeneration from root-tips was obtained by the addition of one cytokinin alone to the culture medium (Colli and Kerbauy 1993; Park et al. 2003; Peres et al. 1999). On the other hand, Sánchez (1988) increased the direct plant regeneration from Cyrtpodium punctatum root-tips adding coconut milk, a substance rich in cytokinins, to the basal medium. The beneficial effects of TDZ, a potent cytokinin for plant tissue culture (Huetteman and Preece 1993), on in vitro plant propagation found in this work are in agreement with the results obtained in other orchid genera such as Phalaenopsis (Chen and Piluek 1995; Chen et al. 2000; Ernst 1994), Doritaenopsis (Ernst 1994), Cymbidium (Chang and Chang 1998; Nayak et al. 1997b; 1998), Dendrobium (Nayak et al. 1997b), and Oncidium (Chen and Chang 2000; Chen et al. 1999).

In spite of the recognized limited morphogenetic competence of root-tip of higher plants, the utility of root explants for orchid micropropagation purposes is being increasingly realized due to their year round availability, low oxidation rate, and the ease with which they can be explanted (Chugh et al. 2009). 
3- Seed cryopreservation: The aim of this study was to adjust a cryopreservation protocol for immature seeds of $C$. hatschbachii using the encapsulation-dehydration technique (Surenciski et al. 2012). Sterile immature seeds were encapsulated in 3\% sodium alginate polymerized with calcium chloride $\left(\mathrm{CaCl}_{2}\right)$ at $0.1 \mathrm{M}$. Encapsulated seeds were then pre-treated in liquid half-strength MS enriched with a progressively increasing sucrose concentration, using the following sequence: $0.08 \mathrm{M}(24 \mathrm{~h}) ; 0.15 \mathrm{M}(24 \mathrm{~h}) ; 0.25 \mathrm{M}(48 \mathrm{~h}) ; 0.5 \mathrm{M}(24 \mathrm{~h})$ and $0.75 \mathrm{M}$ $(24 \mathrm{~h})$. Pre-treatment was performed by placing samples at $27^{\circ} \mathrm{C}$ on an orbital shaker at 60 rpm. After pre-treatment, the beads were surface-dried on filter paper and dehydrated using silica gel for $5 \mathrm{~h}$ (equivalent to capsule MC of 18\%, fresh weight basis). Samples were then placed into cryotubes and rapidly immersed in LN. After $12 \mathrm{~h}$ cryostorage, samples were rewarmed by immersing the cryotubes in a water-bath at $30^{\circ} \mathrm{C}$ for $1 \mathrm{~min}$. Encapsulated seeds were then pos-treated in liquid half-strength MS enriched with a progressively decreasing sucrose concentration: $0.75 \mathrm{M}(24 \mathrm{~h}) ; 0.5 \mathrm{M}(24 \mathrm{~h}) ; 0.25 \mathrm{M}(48 \mathrm{~h}) ; 0.15 \mathrm{M}(24 \mathrm{~h})$ and $0.08 \mathrm{M}$ $(24 \mathrm{~h})$; on an orbital shaker at $60 \mathrm{rpm}$. The beads were then transferred to semisolid germination medium (MS $+3 \%$ sucrose +2 g. $\mathrm{L}^{-1}$ activated charcoal $+0.7 \%$ agar) for recovery. Seed survival was registered 45 days after culture by counting the seeds with hypertrophied embryos and those which developed protocorms.

Using the encapsulation-dehydration technique, cryopreservation of $C$. hatschbachii immature seeds was achieved with high survival rates (64\%). Following this protocol, the seed germination percentage was significantly higher than means obtained in other treatments, even compared with control treatments (-LN). This phenomenon could be attributed to seed coat damage during cooling-rewarming cycles (Tikhonova et al. 1997) that enhances seed permeability, allowing the uptake of nutrients from the culture medium. Results from this study agree with those obtained by Popova et al. (2003) and Popov et al. (2004) who also observed a rapid growth of cryopreserved seeds and the subsequent protocorm develop in the orchid hybrid Bratonia.

A high percentage of protocorms from both cryopreserved and non-cryopreserved seeds showed continuous growth (in the same medium devoid of any plant growth regulator) and developed whole plantlets with normal vegetative morphology, which were successfully transferred to pots and acclimatized to greenhouse conditions. There were no phenotypic differences when compared plants derived from cryopreserved and non-cryopreserved seeds, 10 months after plants transference to ex vitro growth conditions. In addition, the cytogenetic stability was confirmed for plants derived from cryopreserved seeds (Surenciski et al. 2007).

In this work, the encapsulation-dehydration technique was applied for the first time in the Cyrtopodium genus in order to achieve the long term conservation of immature seeds of $C$. hatschbachii. This technique does not require toxic cryoprotectors like dimetilsulfoxid (DMSO) and ethilenglycol, used in other vitrification techniques. This work opens the possibility of using the encapsulation-dehydration technique in other Cyrtopodium species and Orchidaceae members.

\section{Genus: Habenaria}

The genus Habenaria (Subfamily Orchidoideae, Tribe Orchideae, Subtribe Habenariinae) has a pantropical distribution, with about 600 species (Hoehne 1940), mainly from perennial, terrestrial and wetland habits. In Argentina, 21 species of Habenaria are known; four of these 
inhabit the Ibera macrosystem. The Ibera macrosystem, a protected natural area, is the second-largest wetland ecosystem in South America, and supports 57\% of the 2,640 plant species documented in the Province of Corrientes, Argentina (Tressens and Arbo 2002).

Habenaria bractescens Lindl. inhabits river bank and wetland environments in Brazil, Uruguay, Paraguay and Argentina and is rare even in its natural habitat (Johnson 2001). It is characterized by the production of resupinate white flowers with a fringed lip and long slender spur, inserted in a terminal, pauciflorous inflorescence. $H$. bractescens has three types of underground organs: absorbing roots, droppers and root tubers. Absorbing roots are those that possess a typical structure consisting of a radical meristem tip with a root cap, followed by cell division and elongation zones, a root hair zone, and a maturation zone where lateral roots originate. Droppers are organs that grow downward, either vertically or obliquely, and terminate in a root tuber. Root tubers are swollen storage roots that bear shoot buds (Bell 1991; Pridgeon and Chase 1995). The formation of this storage organ is related to a phenomenon known as tuberization.

Many terrestrial and wetland orchids form storage organs, such as root tubers and rhizomes, which are important in their propagation (Pridgeon et al. 1999; 2001; 2003). Root tubers are typical vegetative plant propagules of Orchidoideae subfamily, which can survive in dry or cold conditions as dormant organs. These storage organs are very common in Orchidinae subtribe group 2 (Habenariinae sen. auct.) in the Orchideae tribe (Pridgeon et al. 2001).

Staff of the IBONE has made important advances on in vitro plant regeneration and root tuber differentiation of $H$. bractescens (Medina et al. 2009). Results from this research are briefly presenting below.

1 - In vitro plant regeneration and ex vitro acclimation: In vitro plants of $H$. bractescens derived by seed germination and grown on full-strength MS devoid of plant growth regulator and incubated under a 14-h light/10-h dark photoperiod $\left(116 \mu \mathrm{mol} \cdot \mathrm{m}^{-2} \cdot \mathrm{s}^{-1} \mathrm{PPFD}\right)$ were used as a source of explants in this experiment (Figure 7). Multinodal stem segments (at least five nodes and $2 \mathrm{~cm}$ long) were dissected from in vitro plants and used as explants for the micropropagation assay. A total of 12 culture media were assessed, which were constituted by full-strength MS supplemented with different concentrations and combinations of BAP ( 0 , $4.4,22.2,44.4 \mu \mathrm{M})$ and sucrose $(87.6,146.7$ and $292.1 \mathrm{mM})$. After 45 days of culture, multinodal segments regenerated shoots (upright leafy shoots), swollen buds (similar to pseudobulbs), and/or root tubers (Figure 8) depending on the culture media. Shoot differentiation decreased with increasing BAP concentration regardless of the sucrose concentration. BAP-free media did not promote the growth of swollen buds, regardless of sucrose concentration. BAP supplementation stimulated the differentiation of swollen buds; however, in media with high sucrose concentration $(292.2 \mathrm{mM})$ this capacity decreased. High sucrose concentration also had a depressive effect on the number of shoots and swollen buds regenerated per explant. 


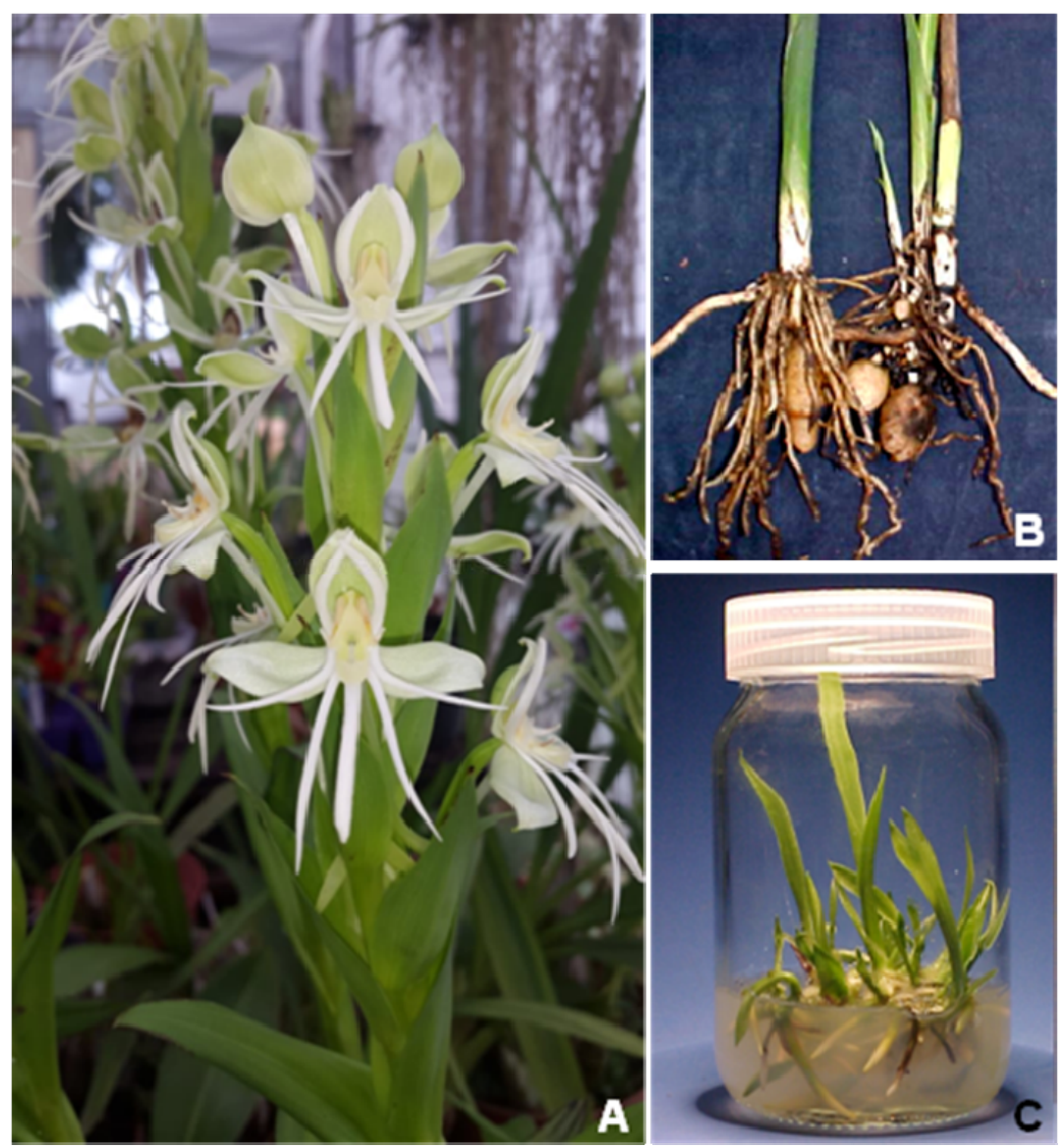

Figure 7 (A) Habenaria bractescens plants of the working collection maintained in the greenhouse. (B) In vivo underground organs of $H$. bractescens. (C) In vitro plants used as source of explants for the organogenesis and plant regeneration experiments.

Shoots, swollen buds, and root tubers developed on the different culture media were transferred separately to MS basal medium (87.6 mM sucrose) to complete plant regeneration. After 60 days of culture, upright leafy shoots produced on BAP-free media or media supplemented with 4.4 or $22.2 \mu \mathrm{M}$ BAP and sucrose at the three concentrations evaluated were able to develop complete plants when transferred to MS basal medium; however, none of the shoots obtained with $44.4 \mu \mathrm{M}$ BAP regenerated plants regardless of the sucrose concentration. On the other hand, swollen buds differentiated in all the media were able to regenerate plants. Plant regeneration percentage from swollen buds developed on MS supplemented with $146.7 \mathrm{mM}$ sucrose and $4.4 \mu \mathrm{M}$ BAP was statistically different to the plant regeneration through swollen buds produced on MS with the same sucrose level but with 44.4 $\mu \mathrm{M}$ BAP as well as on MS with $292 \mathrm{mM}$ sucrose regardless of the BAP concentration. Root tubers differentiated in all the responsive media were able to regenerate plants in percentages between 93 to $98 \%$.

In vitro plants derived from upright leafy shoots, swollen buds, and root tubers were removed from glass flasks, soaked in tap water to remove the remaining culture medium and rinsed carefully. They were submerged in fungicide solution for $30 \mathrm{~min}$ and then transplanted into a mixture of Sphagnum moss, humus and perlite in plastic containers for ex vitro acclimation. Plants derived from in vitro upright leafy shoots and swollen buds were incubated in a humidity chamber at $90 \%$ relative humidity $(\mathrm{RH})$ for 7 days and an irradiance of $160 \mu \mathrm{mol} \mathrm{m} \mathrm{m}^{-2}$. The RH was then gradually decreased to $70 \%$. After 30 days, the pre- 
acclimatized plants were transferred to a greenhouse under $80 \%$ sunlight. On the other hand, plants derived from in vitro root tubers were directly transferred to greenhouse conditions without previous acclimation. After 60 days of transplanted, plants derived from either upright leafy shoots, swollen buds, or root tubers showed similar vegetative morphology to the plants grown under wild conditions; however, the ex vitro survival ratio was significantly dependent from the explant origin. Plant derived by root tubers had the highest survival rate $(95 \%)$ and in all cases they sprouted and rooted, allowing the regeneration of vigorous and healthy plants regardless to origin media.

2- In vitro root tuber differentiation: On the other hand, 45 days after culture of multinodal segments on MS with different concentrations and combinations of BAP and sucrose, typical $H$. bractescens underground organs were regenerated in vitro (i.e. absorbing roots with abundant root hairs, thin root-like structures called droppers, and root tubers in different maturation stages) in a relative proportion per explant depending on culture media. It was observed immature root tubers derived from the swollen apical portion of the dropper and mature root tubers with an emerging bud. These root tubers originated from a slender dropper or from a very short dropper that emerged from the stem. Two weeks after root tuber formation, root tubers sprouted from the expanding bud. In all cases, 2-9 absorbing roots were observed on each explant, and in some media, absorbing roots were the only type of underground organ formed. The addition of BAP increased the number of droppers that differentiated per explant and the number of droppers that developed root tubers, except at the highest sucrose concentrations with 22.2 and $44.4 \mu \mathrm{M}$ BAP. In BAP-free medium containing 146.7 or $292.1 \mathrm{mM}$ sucrose, the number of droppers per explant was reduced to $50 \%$ of that in media with $87.6 \mathrm{mM}$ sucrose. In the culture media with $87.6 \mathrm{mM}$ sucrose combined with the different BAP concentrations, the number of droppers per explant remained constant $(2$ per explant). However, the presence of BAP in combination with $146.7 \mathrm{mM}$ sucrose increased the number of droppers per explant to three per explant, regardless of the BAP concentration. Media with $292.1 \mathrm{mM}$ sucrose and 4.4 $\mu \mathrm{M}$ BAP produced the highest number of droppers per explant; however, higher BAP concentrations inhibited dropper regeneration. Root tuber formation was influenced by media composition. At 45 days, root tuber differentiation was promoted in 8 of the 12 culture media assayed, earlier than for container-grown specimens from the Ibera macrosystem (ca. 3-4 months after planting). The root tuber originated from the distal end of a dropper between the bud and the root apical meristem. Tuberization took place when the apical portion of the dropper underwent radial expansion, maintaining the typical radical structure, and the cortical parenchyma had starch granules. One of the most effective media for root tuber regeneration was the MS with $87.6 \mathrm{mM}$ sucrose plus $4.4 \mu \mathrm{M}$ BAP. In all cases, each explant produced one root tuber. 

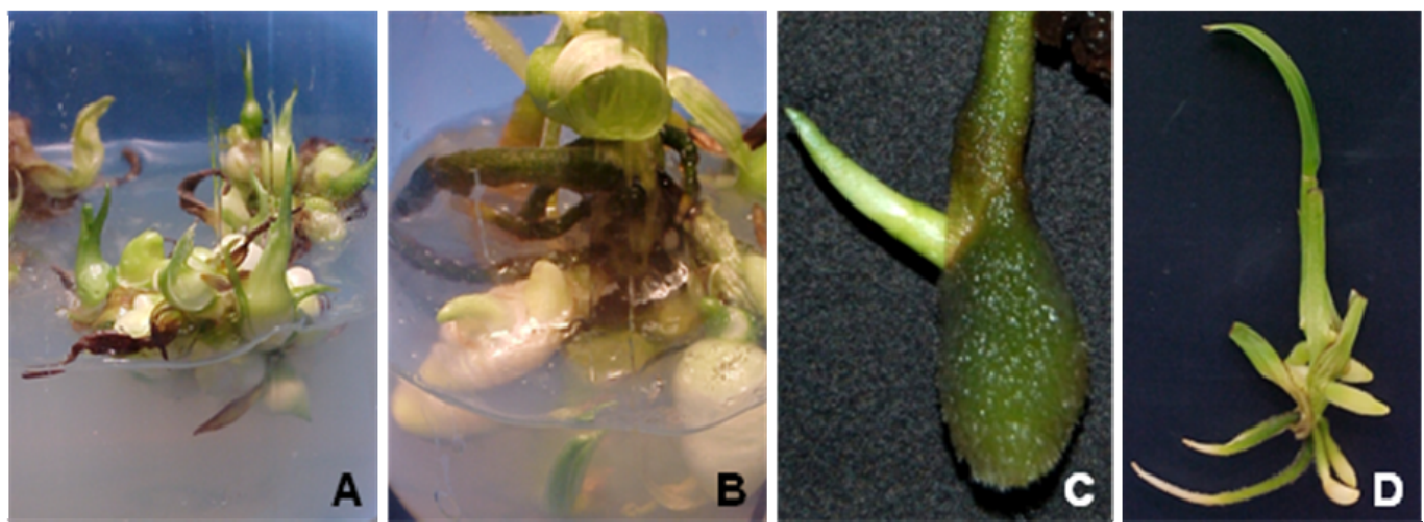

Figure 8 Habenaria bractescens morphogenesis from multinodal segments after 45 days of culture on MS supplemented with different concentrations and combinations of BAP and sucrose. (A-B) In vitro regenerated swollen buds (A) and root tubers (B). (C) Sprouted in vitro root tuber. (D) In vitro regenerated plant showing different underground organs.

Terrestrial orchids can be propagated through several in vitro procedures to produce a large number of healthy plants. However, plants derived from symbiotic or asymbiotic seed germination or through vegetative explant multiplication are generally fragile and poorly survive after transplanting in comparison to plants derived by the sprouting of robust or fieldhardy propagules such as root tubers. Thus, the production of storage organs would be the ideal method for restoration or reintroduction programs of this orchid species. The protocol for in vitro root tuber formation for $H$. bractescens established by Medina et al. (2009) provides a novel system for the controlled and reliable development of root tubers. In summary, MS medium supplemented with $87.6 \mathrm{mM}$ sucrose plus $4.4 \mu \mathrm{M}$ BAP was one of the most effective for stimulating root tubers, the ideal explant for successfully ex vitro transplantation without any acclimation process.

\section{General Conclusion}

Considering that South America is a megadiverse continent in orchid species as well as in other plant families, there is no doubt that orchids are a key group for biodiversity conservation. They are visible and fascinating examples of the natural world and they are seriously threatened by human activities (deforestation, habitat fragmentation, illegal trade, and possibly global warming). However, there is still time to conserve the high orchid diversity that remains and efforts can be successful if we act immediately. Moreover, orchids can play a key role on conservation efforts due to their importance as charismatic species and as a "flag" group whose conservation will help protect many other species and habitats. The task of orchid conservation is multi-faceted and must combine protection of habitats, increase in knowledge about the species and their distribution, coordinated efforts on both in situ and ex situ actions, disclosure of information, promotion of knowledge and awareness networks, between others.

This chapter reviewed the progresses of different in vitro approaches for orchid propagation and germplasm conservation, safeguarding the genetic biodiversity of these species. Several study cases were presented and described to exemplify the protocols developed in the IBONE for propagating and long-term storing the germplasm of Argentine 
orchids. Moreover, it has been attempted to put together most of the available literature on in vitro propagation and germplasm conservation for South American orchids using different explants and procedures (Tables 1-3). There are researches of good scientific quality that even cover critical insights into the physiology and factors affecting growth and development as well as storage of several orchid materials. Anyway, studies are still necessary to increase the number of species evaluated as well as the use of selected material (clonal) for both propagation and conservation approaches.

Acknowledgements Authors gratefully acknowledge to UNNE (PI 16A010), CONICET (PI $11220150100398 \mathrm{CO}$ ), and ANPCyT (PICT 2017 - 3179) for the financial support.

\section{REFERENCES}

Abraham S, Augustine J, Thomas TD (2012) Asymbiotic seed germination and in vitro conservation of Coelogyne nervosa A. Rhich. an endemic orchid to Western Ghats. Physiol Mol Biol Plants 18(2):245-251. doi: 10.1007/s12298-012-0118-6

Aggarwal S, Zettler LW (2010) Reintroduction of an endangered terrestrial orchid Dactylorhiza hatagirea (D. Don) Soo assisted by symbiotic seed germination: first report from the Indian subcontinent. Nat Sci 8(10):139-145

Almeida V, Fraga HPF, Navarro BB, Guerra MP, Pescador R (2017) Dynamics in global DNA methylation and endogenous polyamine levels during protocorm-like bodies induction of Cattleya tigrina A. Richard. Acta Sci Biol Sci 39(4)497-505. doi:10.4025/actascibiolsci.v39i4.36656

Alvarez-Pardo V, Gui Ferreira A (2006) Armazenamento de sementes de orquídeas. Rev Bras Sem 28(2):92-98. doi:10.1590/s0101-31222006000100013

Andrade-Souza V, Almeida A-AF, Corrêa RX, Costa MA, Mielke MS, Gomes FP (2009) Leaf carbon assimilation and molecular phylogeny in Cattleya. Genet Mol Res 8(3):976989. doi:10.4238/vol8-3gmr618

Arditti J (1967) Factors affecting the germination of orchid seeds. Bot Rev 33:1-97. doi:10.1007/BF02858656

Arditti J (1968) Germination and growth of orchids on banana fruit tissue and some of its extracts. Am Orchid Soc Bull 37:112-116

Arditti J (1992) Fundamentals of orchid biology. John Wiley \& Sons Inc, New York, 704 p

Arditti J (2008) Micropropagation of orchids. $2^{\circ}$ ed. Wiley-Blackwell, Cambridge, $1560 \mathrm{p}$

Arditti J, Ernst R (1993) Micropropagation of orchids. John Wiley \& Sons Inc, NY, 682 p

Arditti J, Krikorian AD (1996) Orchid micropropagation: The path from laboratory to commercialization and an account of several unappreciated investigators. Bot J Linn Soc 122:183-241. doi:10.1111/j.1095-8339.1996.tb02073.x

Ashmore SE (1997) Current in vitro conservation techniques. In: Engelmann F (ed) Status report on the development and application of in vitro techniques for the conservation and use of plant genetic resources. Intl Plant Genet Resources Inst, Rome, pp 5-18

Ashmore SE, Hamilton KN, Offord CA (2011) Conservation technologies for safeguarding and restoring threatened flora: case studies from Eastern Australia. In Vitro Cell Dev Biol Plant 47:99-109. doi:10.1007/s11627-010-9320-9 
Barbery Knaudt R, Morales Benavent I (2011) Manual para el cultivo in vitro de la orquídea Cattleya nobilior. Flor símbolo de Concepción. CEPAD, Editorial El País, Santa Cruz, 46 $\mathrm{pp}$

Bell AD (1991) Plant form: an illustrated guide to flowering plant morphology. Oxford University Press, NY, 341p

Benson EE (2008) Cryopreservation of phytodiversity: a critical appraisal of theory and practice. Crit Rev Plant Sci 27:141-219. doi:10.1080/07352680802202034

Bianco C, Cantero JJ (1985) Las especies de Orchidaceae del suroeste de la provincia de Cordoba. Revista de la Universidad Nacional de Rio Cuarto 5:131-141

Cagnolo L, Cabido M, Valladares G (2006) Plant species richness in the Chaco Serrano Woodland from central Argentina: ecological traits and habitat fragmentation effects. Biol Conserv 132:510-519. doi:10.1016/j.biocon.2006.05.012

Calderón-Sáenz E. (ed) (2007). Libro rojo de plantas de Colombia. Volumen 6: Orquídeas, Primera Parte. Serie Libros Rojos de Especies Amenazadas de Colombia. Instituto Alexander von Humboldt. Ministerio de Ambiente, Vivienda y Desarrollo Territorial, Bogotá, $820 \mathrm{pp}$

Caovila LE, Gianini PF, De Moraes CP (2016) Concentração de sacarose e índices de pH no crescimento in vitro de Oncidium flexuosum Sims. (Orchidaceae). Rev Agro Amb 9(3):531-545. doi:10.17765/2176-9168.2016v9n3p531-545

Cardoso JC (2014) Levantamento de espécies da família Orchidaceae em Botucatu: potencial ornamental e cultivo. Hortic Bras 32:7-13. doi:10.1590/s0102-05362014000100002

Cardoso JC, Israel M (2005) Levantamento de espécies da família Orchidaceae em Águas de Sta. Bárbara (SP) e seu cultivo. Hortic Bras 23(2):169-173. doi:10.1590/S010205362005000200001

Cardoso JC, Ono EO (2011) In vitro growth of Brassocattleya orchid hybrid in different concentrations of KNO3, NH4NO3 and benzylaminopurine. Hortic Bras 29: 359-363. doi:10.1590/S0102-05362011000300017

Carnevali Fernandez-Concha G, Cetzal-Ix WR, Balam Narvaez R, Romero-Gonzalez GA (2010) A synopsis of Cohniella (Orchidaceae, Oncidiinae). Brittonia 62:153-177. doi:10.1007/s12228-009-9115-7

Carnevali G, Cetzal-Ix W, Balam R (2014) A new species of mule-ear Oncidium with strawyellow flowers (Orchidaceae: Oncidiinae, Lophiaris) from central Panama. Phytotaxa 162:165-173. doi:10.11646/phytotaxa.162.3.5

Cavalcante Martini P, Willadino L, Dias Alves G, Tenório Sabino Donato VM (2001) Propagação de orquídea Gongora quinquenervis por semeadura in vitro. Pesq Agropec Bras 36(10):1319-1324. doi: 10.1590/S0100-204X2001001000015

Cavelier J, Etter A (1995) Deforestation of montane forests in Colombia as a result of illegal plantations of opium (Papaver somniferum). In: Churchill SP, Balslev H, Forero E, Luteyn JL (eds) Biodiversity and conservation of neotropical montane forests. New York Botanic Garden, Bronx, NY, pp 541-550

Cellini JM, Salomón L, García R, Cellini L, Cellini L, Sánchez M (2009) Limite sur del área de distribución de Oncidium bifolium Sims. (Orchidaceae). Bol Soc Argent Bot 44(supl):83

Cerna M, Aucapiña C, López, P (2016) Definición de protocolos para el uso de fitohormonas en el crecimiento de orquídeas a nivel in vitro. Olmedo GF (ed) ESPE: Revista Congreso de Ciencia y Tecnología 11:12-19 
Cerna M, Valdivieso P, Cella R, Mátyás B, Aucapiña C (2018) Cryopreservation of orchid seeds through rapid and step freezing methods. F1000Res 7:209. doi:10.12688/f1000research.13622.1

Cetzal-Ix W, Carnevali Fernández-Concha G, Paiva Castro V (2012) Cohniella (Orchidaceae: Oncidiinae) South of the Amazon River. Syst Bot 37(1):58-77. doi:10.1600/036364412X616648

Chang C, Chang WC (1998) Plant regeneration from callus culture of Cymbidium ensifolium var. misericors. Plant Cell Rep 17:251-255

Chang C, Sung PG, Chang CH, Chen YC, Lin YH (2006) Seed development and storage of Bletilla formosana (Hayata) Schltr. Seed Nursery 8:29-38

Chase MW, Williams NH, Donisete de Faria A, Neubig KM, Amaral ME, Whitten WH (2009) Floral convergence in Oncidiinae (Cymbidiae, Orchidaceae): an expanded concept of Gomesa and a new genus Nohawilliamsia. Ann Bot 104:387-402. doi:10.1093/aob/mcp067

Chávez HK, Mosquera-Espinosa AT, Otero Ospina JT (2014) Propagación in vitro de semillas de la orquídea Comparettia falcata Poepp. \& Endl. (Orchidaceae) mediante técnicas simbióticas y asimbióticas. Acta Agron 64(2):125-133. doi:10.15446/acag.v64n2.42976

Chen Y, Piluek C (1995) Effects of thidiazuron and N6-benzylaminopurine on shoot regeneration of Phalaenopsis. Plant Growth Regul 16:99-101. doi:10.1007/BF00040513

Chen JT, Chang WC (2000) Plant regeneration via embryo and shoot bud formation from flower-stalk explants of Oncidium Sweet Sugar. Plant Cell Tissue Org Cult 62:95-100. doi:10.1023/A:1026591003553

Chen JT, Chang C, Chang WC (1999) Direct somatic embryogenesis on leaf explants on Oncidium Gower Ramsey and subsequent plant regeneration. Plant Cell Rep 19:143-149. doi:10.1007/s002990050724

Chen YC, Chang C, Chang WC (2000) A reliable protocol for plant regeneration from callus culture of Phalaenopsis. In Vitro Cell Dev Biol Plant 36:420-423. doi:10.1007/s11627000-0076-5

Chen LR, Chen JT, Chang WC (2002) Efficient propagation of protocorm-like bodies and plant regeneration from flower stalk explants of the sympodial orchid Epidendrum radicans. In Vitro Cell Dev Biol Plant 38:441-445. doi:10.1079/IVP2002315

Chen Y, Goodale UM, Fan XL, Gao JY (2015) Asymbiotic seed germination and in vitro seedling development of Paphiopedilum spiceriaum: an orchid with an extremely small population in China. Glob Ecol Conserv 3:367-78. doi:10.1016/j.gecco.2015.01.002

Chugh S, Guha S, Rao IU (2009) Micropropagation of orchids: a review on the potential of different explants. Sci Hortic 122:507-520. doi:10.1016/j.scienta.2009.07.016

Colli S, Kerbauy GB (1993) Direct root tip conversion of Catasetum into protocorm-like bodies. Effects of auxin and cytokinin. Plant Cell Tissue Organ Cult 33:39-44. doi:10.1007/BF01997596

Condemarín-Montealegre CE, Chico-Ruíz J, Vargas-Artaega C (2007) Efecto del ácido indolbutírico (IBA) y 6-bencilaminopurina (BAP) en el desarrollo in vitro de yemas axilares de Encyclia microtos (Rchb.f.) Hoehne (Orchidaceae). Lankesteriana 7(1-2):247254. doi:10.15517/LANK.V7I1-2.19513

Convention on International Trade in Endangered Species of Wild Fauna and Flora (CITES) (http://www.cites.org) 
Corrêa Pereira M, Pereira Torres D, Rodrigues Guimarães FA, Liparini Pereira O, Megumi Kasuya MC (2011) Germinação de sementes e desenvolvimento de protocormos de Epidendrum secundum Jacq. (Orchidaceae) em associação com fungos micorrízicos do gênero Epulorhiza. Acta Bot Bras 25(3):534-541. doi:10.1590/S010233062011000300004

Corrêa Pereira M, Rocha DI, Gomes Reis Veloso T, Liparini Pereira O, Francino DMT, Strozi Alves Meira RM, Megumi Kasuya MC (2015) Characterization of seed germination and protocorm development of Cyrtopodium glutiniferum (Orchidaceae) promoted by mycorrhizal fungi Epulorhiza spp. Acta Bot Bras 29(4):567-574. doi:10.1590/0102-33062015abb0078

Cribb PJ, Kell SP, Dixon KW, Barrett RL (2003) Orchid conservation: a global perspective. In: Dixon KW, Kell SP, Barrett RL, Cribb PJ (eds) Orchid conservation. Natural History Publications, Kota Kinabalu, Sabah, pp 1-24. doi:10.1186/s40529-018-0232-z

Cueva-Agila A, Concia L, Cella R (2012) Molecular characterization of a Cyrtochilum loxense Somatic Embryogenesis Receptor-like Kinase (SERK) gene expressed during somatic embryogenesis. Plant Cell Rep 31(6):1129-1139. doi:10.1007/s00299-012-1236$\mathrm{x}$

Cueva-Agila AY, Guachizaca I, Cella R (2013) Combination of 2,4-D and stress improves indirect somatic embryogenesis in Cattleya maxima Lindl. Plant Biosys 149(2):235-241. doi:10.1080/11263504.2013.797033

Cueva-Agila AY, Medina J, Concia L, Cella R (2015) Effects of plant growth regulator, auxin polar transport inhibitors on somatic embryogenesis and CmSERK gene expression in Cattleya maxima (Lindl.). In: Mujib A (ed) Somatic embryogenesis in ornamentals and its applications. Springer, New Delhi, pp 255-267. doi:10.1007/978-81-322-2683-3

Cuoco LB, Cronan JB (2009) Orchidaceae: using a globalized commodity to promote conservation and sustainable economic development in Southern Ecuador. J Sustainable For 28:799-824. doi:10.1080/10549810902936623

Da Silva ALL, Da Luz Costa J, Gollo AL, Dos Santos JD, Forneck HR, Biasi LA, Soccol VT, De Carvalho JC, Soccol CR (2014) Development of a vinasse culture medium for plant tissue culture. Pak J Bot 46(6):2195-2202

Da Silva Júnior JM, de Castro EM, Rodrigues M, Pasqual M, Vilela Bertolucci SK (2012) Variações anatômicas de Laelia purpurata var. cárnea cultivada in vitro sob diferentes intensidades e qualidade spectral de luz. Ciênc Rural Santa Maria 42(3):480-486. doi:10.1590/S0103-84782012000300015

Da Silva Júnior JM, Rodrigues M, Mauro de Castro E, Vilela Bertolucci SK, Pasqual M (2013) Changes in anatomy and chlorophyll synthesis in orchids propagated in vitro in the presence of urea. Acta Sci Agron 35(1)65-72. doi:10.4025/actasciagron.v35i1.15356

David D, Jawan R, Marbawi H, Gansau JA (2015) Organic additives improves the in vitro growth of native orchid Vanda belvola Blume. Not Sci Biol 7(2):192-197. doi:10.15835/nsb.7.2.9546

De Carvalho OC, de Paiva Neto VB, Padilha DRC, Veloso TGR, Bocayuva MF, Soares DCO, Kasuya MCM (2018) Cyrtopodium paludicolum germination with two Tulasnella isolates. Acta Bot Bras 32(1):107-112. doi:10.1590/0102-33062017abb0181

De Conti D, Corredor-Prado JP, Junior DR, Suzuki RM, Guerra MP, Pescador R (2018) Determination of endogenous IAA and carbohydrates during the induction and 
development of protocorm-like bodies of Cattleya tigrina A. Richard. Acta Sci Biol Sci 40:e37874. doi:10.4025/actascibiolsci.v40i1.37874

De Melo Ferreira W, De Vasconcelos MC, Silva CCN, De Oliveira HR, Suzuki RM (2017) Asymbiotic germination, multiplication and development of Alatiglossum fuscopetalum (Orchidaceæ) as affected by culture medium, sucrose and growth regulators. Iheringia Ser Bot 72(1):57-65. doi:10.21826/2446-8231201772106

De Menezes Gonçalves L, Prizão EC, Milaneze Gutierre MA, Mangolin CA, Pires da Silva Machado MF (2012) Use of complex supplements and light-differential effects for micropropagation of Hadrolaelia purpurata (= Laelia purpurata) and Encyclia randii orchids. Acta Sci Agron 34(4):459-463. doi:10.4025/actasciagron.v34i4.12333

De Menezes Gonçalves L, Machado MFPS, Ballesta P, Mora F, Milaneze Gutierre MA, Mangolin CA (2016) Suplementos orgánicos para el cultivo in vitro del híbrido Laeliocattleya (Orchidaceae). IDESIA 34(1):47-54. doi:10.4067/S071834292016000100006

De Sousa Silva C, Garcês de Araújo L, Sousa KCI, Campos Borba de Carvalho J, de Almeida Gonçalves L, Lajovic Carneiro L (2016) In vitro culture of Epidendrum nocturnum (Orchidaceae) occurring in the Cerrado in Central-West region. Rodriguésia 67(4):10831091. doi:10.1590/2175-7860201667418

Decruse SW, Gangaprasad A, Seeni S, Menon S (2003) A protocol for shoot multiplication from foliar meristem of Vanda spathulata (L.) Spreng. Indian J Exp Biol 41:924-927

Dezan LF, Canassa F, de Souza-Leal T, Diogo JA, Massaro R, Cordeiro GM, Pedroso-deMoraes C (2012) Crescimento in vitro de Schomburgkia gloriosa Lindl. em meio de cultivo simplificados. IDESIA 30(2):53-58. doi:10.4067/S0718-34292012000200007

Díaz-Álvarez EA, Torres-Galeano C, Rojas-Cortés ÁP, De La Barrera E (2015) In vitro germination and development of two endangered endemic Colombian orchids Cattleya mendelii and Cattleya quadricolor. Gayana Bot 72(2):213-220. doi:10.4067/S071766432015000200005

Dignart SL, de Castro EM, Pasqual M, Ferronato A, Tavares Braga F, Paiva R (2009) Sunlight and sucrose concentrations on in vitro culture of Cattleya walkeriana. Ciênc Agrotec Lavras 33(3):780-787. doi:10.1590/S1413-70542009000300017

Dodson C, Escobar R (1993) Native Ecuadorian orchids (Vol 1). Compañía Litográfica Nacional SA, Medillín, Colombia

Dolce NR, Medina RD, Mroginski LA, Rey HY (2016) Storage of Cohniella cepula (Orchidaceae) pollinia: fertilizing ability and subsequent fruit and seed formation. HortScience 51(10):1265-1269. doi:10.21273/HORTSCI10903-16

Dolce NR, González-Arnao MT (2018) Cryopreservation as a tool for long-term storage of Cohniella cepula (Orchidaceae) seeds. Acta Hortic (in press)

Dolce NR, Hernández-Ramírez F, González-Arnao MT (2018) Cryopreservation of vanilla (Vanilla planifolia) root-tips: a new alternative for in vitro long-term storage of its germplasm. Acta Hortic (in press)

Dorneles LT, Trevelin V (2011) Aclimatização e reintrodução de Cattleya intermedia Graham ex Hook (Orchidaceae) obtidas por propagação in vitro. Iheringia Ser Bot 66(2):167-174

Duarte ER, Mangeón V, Küppers G, Rocha P, Niella F (2017) Tamaño y viabilidad de semillas: implicancias en la evolución y conservación de Phaius tankervilleae (Orchidaceae). Caldasia 39(2):388-399. doi:10.15446/caldasia.v39n2.62184 
Dutra D, Johnson TR, Kauth PJ, Stewart SL, Kane ME, Richardson L (2008) Asymbiotic seed germination, in vitro seedling development, and greenhouse acclimation of the threatened terrestrial orchid Bletia purpurea. Plant Cell Tissue Organ Cult 94:11-21. doi:10.1007/s11240-008-9382-0

Endres Júnior D, Hisayuki Sasamori M, Droste A (2014) In vitro propagation of Anathallis adenochila (Loefgr.) F. Barros (Orchidaceae), a species endemic to southern and southeastern Brazil. Acta Bot Bras 28(4):489-494. doi:10.1590/0102-33062014abb3158

Engelmann F (2004) Plant cryopreservation: progress and prospects. In Vitro Cell Dev Biol Plant 40:427-433. doi:10.1079/IVP2004541

Engelmann F (2011) Use of biotechnologies for the conservation of plant biodiversity. In Vitro Cell Dev Biol Plant 47:5-16. doi:10.1007/s11627-010-9327-2

Ernst R (1994) Effects of thidiazuron on in vitro propagation of Phalaenopsis and Doritaenopsis (Orchidaceae). Plant Cell Tissue Org Cult 39:273-275. doi:10.1007/BF00035982

Eymar E, Alegre J, Toribio M, López-Vela D (2000) Effect of activated charcoal and 6benzyladenine on in vitro nitrogen uptake by Lagerstroemia indica. Plant Cell Tissue Org Cult 63:57-65. doi:10.1023/A:1006471519609

Fandiño-Lozano M, van Wyngaarden W (2005) Prioridades de conservación biológica para Colombia. Grupo ARCO, Bogotá, 188 p

Farrell L, Fitzgerald R (1989) The nature conservancy council and orchid conservation. In: Pritchard HW (ed) Modern methods in orchid conservation: the role of physiology, ecology and management. Cambridge University Press, pp 147-51. doi:10.1017/CBO9780511551307

Favetta V, Colombo RC, Mangili Júnior JF, Tadeu de Faria R (2017) Light sources and culture media in the in vitro growth of the Brazilian orchid Microlaelia lundii. Semina: Ciencias Agrarias 38(4):1775-1784. doi:10.5433/1679-0359.2017v38n4p1775

Firon N, Nepi M, Pacini E (2012) Water status and associated processes mark critical stages in pollen development and functioning. Ann Bot 109:1201-1214. doi: $10.1093 / \mathrm{aob} / \mathrm{mcs} 070$

Flachsland E, Terada G, Scocchi A, Rey H, Mroginski L, Engelmann F (2006) Cryopreservation of seeds and in vitro-cultured protocorms of Oncidium bifolium Sims. (Orchidaceae) by encapsulation-dehydration. CryoLett 27(4): 235-242

Flachsland E, Terada G, Fernández JM, Medina R, Schinini A, Rey H, Mroginski L (2011) Plant regeneration from root-tip culture of Cyrtopodium brandonianum Barb. Rodr. (Orchidaceae). Propag Ornam Plants 11(4):184-188

Flanagan NS, Mosquera-Espinosa AT (2016) An integrated strategy for the conservation and sustainable use of native Vanilla species in Colombia. Lankesteriana 16(2):201-218. doi:10.15517/lank.v16i2.26007

Fracchia S, Aranda-Rickert A, Gopar A, Silvani V, Fernandez L, Godeas A (2008) Mycorrhizal status of plant species in the Chaco Serrano Woodland from central Argentina. Mycorrhiza 19:205-214. doi:10.1007/s00572-009-0231-8

Fracchia S, Silvani V, Flachsland E, Terada G, Sede S (2014a) Symbiotic seed germination and protocorm development of $\mathrm{Aa}$ achalensis Schltr., a terrestrial orchid endemic from Argentina. Mycorrhiza 24:35-43. doi:10.1007/s00572-013-0510-2 
Fracchia S, Aranda-Rickert A, Flachsland E, Terada G, Sede S (2014b) Mycorrhizal compatibility and symbiotic reproduction of Gavilea australis, an endangered terrestrial orchid from south Patagonia. Mycorrhiza 24:627-634. doi:10.1007/s00572-014-0579-2

Fracchia S, Aranda-Rickert A, Rothen C, Sede S (2016) Associated fungi, symbiotic germination and in vitro seedling development of the rare Andean terrestrial orchid Chloraea riojana. Flora 224:106-111. doi:10.1016/j.flora.2016.07.008

Franco M, Guevara G, Mesa N, Urueña G (2007) Hardening of the national flower of Colombia, the threatened Cattleya trianae (Orchidaceae), from in vitro culture with previous invigoration phase. Rev Biol Trop 55(2):681-691

Funk V, Hollowell T, Berry P, Kelloff C, Alexander SN (2007) Checklist of the plants of the Guiana Shield (Venezuela: Amazonas, Bolivar, Delta Amacuro; Guyana, Surinam, French Guiana). Contributions from the United States National Herbarium, Department of Botany, National Museum of Natural History. Smithsonian Institution, Washington $\mathrm{DC}, 584 \mathrm{p}$

Galdiano Júnior RF, Nascimbém Pedrinho EA, Luque Castellane TC, de Macedo Lemos EG (2011) Auxin-producing bacteria isolated from the roots of Cattleya walkeriana, an endangered Brazilian orchid, and their role in acclimatization. Rev Bras Ciênc Solo 35:729-737. doi:10.1590/S0100-06832011000300008

Galdiano Júnior RF, Mantovani C, De Macedo Lemos EG (2012a) Propagação in vitro de Cattleya trianaei (Linden \& Reichenbach fil.) (Orchidaceae) em meios de culturas e com doses de fertilizante comercial. Comunicata Scientiae 3(3):210-214

Galdiano Júnior RF, Mantovani C, de Macedo Lemos EG (2012b) Seleção de agentes alternativos ao ágar para propagação de plântulas de Cattleya loddigesii Lindley (Orchidaceae). Rev Bras Ciênc Agrár 7(supl):756-760. doi:10.5039/agraria.v7isa1930

Galdiano Júnior RF, Mantovani C, Olian Cassano A, Macedo Lemos EG (2013) Desenvolvimento inicial e crescimento in vitro de Cattleya violacea (Kunth) Rolfe em diferentes concentrações de sacarose. Acta Amazon 43(2):127-134. doi:10.1590/S004459672013000200001

Galdiano Júnior RF, Mantovani C, Gomes, ES, Gasparino EC, Moro FV, De Macedo Lemos, EG (2014) Seed germination morphology, and in vitro growth of Cattleya walkeriana Gardner under different culture media. Comunicata Scientiae 5(4):456-463

Galdiano Júnior RF, Vendrame WA, Moretto C, de Faria RT, Lemos EGM (2017) Seed cryopreservation, in vitro propagation and ex vitro growth of Cattleya walkeriana Gardner, a vulnerable ornamental orchid. Aust J Crop Sci 11(4):485-490. doi:10.21475/ajcs.17.11.04.384

Geetha S, Shetty SA (2000) In vitro propagation of Vanilla planifolia, a tropical orchid. Curr Sci 71:886-889

Gentry AH (1986) Species richness and floristic composition of Choco region plant communities. Caldasia 15:71-91

Goh CJ, Tan H (1979) Clonal propagation from leaf explants in an orchid hybrid Renanthera ammani. Plant Physiol 63:161

Goh CJ, Wong PF (1990) Micropropagation of the monopodial orchid hybrid Aranda Deborah using inflorescence explants. Sci Hortic 44:315-321. doi:10.1016/03044238(90)90132-X

Gomes de Araújo A, Pasqual M, Almendagna Rodrigues F, Guedes de Carvalho J, Zampiere Arce Zarraga D (2009) Fontes de nitrogênio no crescimento in vitro de plântulas de Cattleya loddigesii Lindl. (Orchidaceae). Acta Sci Biol Sci 31(1):35-39. doi:10.4025/actascibiolsci.v31i1.309 
González JJ, Etter AA, Sarmiento AH, Orrego SA, Ramírez C, Cabrera E, Vargas D, Galindo G, García MC, Ordoñez MF (2011) Análisis de tendencias y patrones espaciales de deforestación en Colombia. Instituto de Hidrología, Meteorología y Estudios Ambientales-IDEAM, Bogotá DC, $64 \mathrm{p}$

González-Arnao MT, Engelmann F (2006) Cryopreservation of plant germplasm using the encapsulation-dehydration technique: Review and case study on sugarcane. CryoLett 27:155-168

González-Arnao MT, Panta A, Roca WM, Escobar RH, Engelmann F (2008) Development and large scale application of cryopreservation techniques for shoot and somatic embryo cultures of tropical crops. Plant Cell Tissue Organ Cult 92:1-13. doi:10.1007/s11240007-9303-7

Gonzalez-Arnao MT, Lazaro-Vallejo CE, Engelmann F, Gamez-Pastrana R, MartinezOcampo Y, Pastelin-Solano MC, Diaz-Ramo C (2009) Multiplication and cryopreservation of vanilla (Vanilla planifolia 'Andrews'). In Vitro Cell Dev Biol Plant 45:574-582. doi:10.1007/s11627-009-9242-6

González-Arnao MT, Dolce NR, González-Benito ME, Castillo Martínez CR, Cruz-Cruz CA (2017) Approaches for in vitro conservation of woody plants germplasm. In: Ahuja MR, Mohan Jain S (eds) Biodiversity and Conservation of Woody Plants. Sustainable Development and Biodiversity Series. Springer, Cham, pp 355-419. doi:10.1007/978-3319-66426-2

Govaerts R (2018) World Checklist of Gomesa. Facilitated by the Royal Botanic Gardens, Kew. Published on the Internet; http://wcsp.science.kew.org/. Accessed 03 Nov 2018

Hay FR, Merritt DJ, Soanes JA, Dixon KW (2010) Comparative longevity of Australian orchid (Orchidaceae) seeds under experimental and low temperature storage conditions. Bot J Linn Soc 164:26-41. doi:10.1111/j.1095-8339.2010.01070.x

Hernández-Ramírez F, González-Arnao MT, Cruz-Cruz C, Pastelin-Solano M, Engelmann F (2014) Comparison of different preconditioning and loading treatments with vanilla (Vanilla planifolia Jack.) apices cryopreserved using the droplet-vitrification procedure. Acta Hortic 1039:173-180. doi:10.17660/ActaHortic.2014.1039.22

Heywood VH, Iriondo JM (2003) Plant conservation: old problems, new perspectives. Biol Cons 113(3):321-335. doi:10.1016/S0006-3207(03)00121-6

Heywood VH, Brummitt RK, Culham AY, Seberg O (2007) Flowering plant families of the world. Firefly Books, Ontario, $424 \mathrm{p}$

Hirano T, Godo T, Mii M, Ishikawa K (2005a) Cryopreservation of immature seeds of Bletilla striata by vitrification. Plant Cell Rep 23(8):534-539. doi:10.1007/s00299-0040893-9

Hirano T, Ishikawa K, Mii M (2005b) Cryopreservation of immature seeds of Ponerorchis graminifolia var. suzukiana by vitrification. CryoLett 26(3):139-146

Hirano T, Godo T, Miyoshi K, Ishikawa K, Ishikawa M, Mii M (2009) Cryopreservation and low-temperature storage of seeds of Phaius tankervilleae. Plant Biotechnol Rep 3:103109. doi:10.1007/s11816-008-0080-5

Hoehne FC (1940). Flora Brasilica, Fasc 12. Secretaria da Agricultura. Indústria e Comércio de São Paulo, São Paulo

Hosomi ST, Santos RB, Custodio CC, Seaton PT, Marks TR, Machado-Neto NB (2011) Preconditioning Cattleya seeds to improve the efficacy of the tetrazolium test for viability. Seed Sci Technol 39(1):178-189. doi:10.15258/sst.2011.39.1.15 
Hosomi ST, Custódio CC, Seaton PT, Marks TR, Machado-Neto NB (2012) Improved assessment of viability and germination of Cattleya (Orchidaceae) seeds following storage. In Vitro Cell Dev Biol Plant 48(1):127-136. doi:10.1007/s11627-011-9404-1

Hosomi ST, Bonome de Souza T, Castilho Custódio C, Barbosa Machado Neto N (2017) Refining the tetrazolium test for evaluation of Cattleya labiata and C. tigrina seeds viability. Aust J Crop Sci 11(10):1320-1326. doi:10.21475/ajcs.17.11.10.pne606

Hossain MM, Dey R (2013) Multiple regeneration pathways in Spathoglottis plicata Blume a study in vitro. South Afr J Bot 85:56-62. doi:10.1016/j.sajb.2012.12.005

Hossain MM, Sharma M, Teixeira da Silva JA, Pathak P (2010) Seed germination and tissue culture of Cymbidium giganteum Wall. ex Lindl. Sci Hortic 123:479-487. doi:10.1016/j.scienta.2009.10.009

Huetteman CA, Preece JE (1993) Thidiazuron: a potent cytokinin for woody plant tissue culture. Plant Cell Tissue Org Cult 33:105-119. doi:10.1007/BF01983223

Insaurralde IS, Radins JA (2007) Misiones orquídeas. Buenos Aires Golden Company, Buenos Aires, $192 \mathrm{pp}$

Instituto de Hidrología, Meteorología y Estudios Ambientales - IDEAM (2017) Tasa anual de deforestación. Subdirección de Ecosistemas e Información Ambiental. Grupo de Bosques. Proyecto Sistema de Monitoreo de Bosques y Carbono. Bogotá DC

Intuwong O, Sagawa Y (1973) Clonal propagation of Sarcanthine orchids by aseptic culture of inflorescence. Am Orchid Soc Bull 42:209-215

Janarthanam B, Seshadri S (2008) Plantlet regeneration from leaf derived callus of Vanilla planifolia Andr. In Vitro Cell Dev Biol Plant 44:84-89. doi:10.1007/s11627-008-9123-4

Johnson E (2001). Las orquídeas del Parque Nacional Iguazú. LOLA, Buenos Aires, 296 pp

Johnson T, Stewart SL, Dutra D, Kane ME, Richardson L (2007) Asymbiotic and symbiotic seed germination of Eulophia alta (Orchidaceae) preliminary evidence for the symbiotic culture advantage. Plant Cell Tissue Organ Cult 90:313-323. doi:10.1007/s11240-0079270-z

Jørgensen PM, Ulloa-Ulloa C, León B, León-Yánez S, Beck SG, Nee M, Zarucchi JL, Celis M, Bernal R, Gradstein R (2011) Regional patterns of vascular plant diversity and endemism. In: Herzog SK, Martínez R, Jørgensen PM, Tiess H (eds) Climate change and biodiversity in the Tropical Andes. Inter-American Institute for Global Change Research (IAI) and Scientific Committee on Problems of the Environment (SCOPE), pp 192-203

Kalimuthu K, Senthikumar R, Murugalatha N (2006) Regeneration and mass multiplication of Vanilla planifolia Andr. - a tropical orchid. Curr Sci 91:1401-1403

Kandavel D, Aiyavu C, Senthilkumar S (2004) Conservation of orchids - a problem oriented approach. In: Britto SJ (ed) Orchids: biodiversity and conservation - a tissue culture approach. INR, St Joseph's college, Tiruchirappalli, pp 1-16

Katoh K, Toh H (2008) Recent developments in the MAFFT multiple sequence alignment program. Brief Bioinform 9:286-298. doi:10.1093/bib/bbn013

Kenny J (2008) Orchids of Trinidad and Tobago. Prospect Press, Maraval, Port of Spain, 118 $\mathrm{p}$

Kerbauy GB (1991) In vitro conversion of Cattleya root tip cells into protocorm like bodies. J Plant Physiol 138:248-251. doi:10.1016/S0176-1617(11)80279-8

Kerbauy GB (1993) Indução in vitro de protocormoides em raíces de Oncidium varicosum. Efeitos de fontes nitrogenadas, auxinas e citocininas. Rev Bras Bot 16:1-8 
Ket NV, Hahn EJ, Park SY, Chakrabarty D, Paek KY (2004) Micropropagation of an endangered orchid Anectochilus formosanus. Biol Plant 48:339-344. doi:10.1023/B:BIOP.0000041084.77832.11

Khalifah RA (1966) Gibberellin-like substances from the developing banana fruit. Plant Phys 41:771-773. doi:10.1104/pp.41.5.771

Khoddamzadeh AA, Sinniah UR, Kadir MA, Kadzimin SB, Mahmood M, Subramaniam S (2010) Detection of somaclonal variation by random amplified polymorphic DNA analysis during micropropagation of Phalaenopsis bellina (Rchb.f.) Christenson. Afr J Biotechnol 9:6632-6639. doi:10.5897/AJB10.714

Knudson L (1922) Nonsymbiotic germination of orchid seeds. Bot Gaz 73:1-7. doi:10.1086/332956

Knudson L (1946) A nutrient for germination of orchid seeds. Am Orchid Soc Bull 15:214217

Kolanowska M (2015) Habenaria fimbriatiloba (Orchidaceae), a new orchid species from China. Phytotaxa 201:96-99. doi:10.11646/phytotaxa.201.1.8

Kondo K, Tatarenko IV, Varghese SB, Iwai Y, Matsumoto KI (2001) Orchid cryopreservation by using induced shoot primordia and protocorm-like bodies of tissue culture. In: Pathak P, Sehgal RN, Shekhar N, Sharma M, Sood A (eds) Orchids: Science and Commerce. Bishen Singh Mahendra Pal Singh, Dehradun, pp 397-412

Koopowitz H (1986) A gene bank to conserve orchids. Am Orchid Soc Bull 55:247-250

Koopowitz H (2001) Orchids and their conservation. Timber Press, Portland, OR, $176 \mathrm{p}$

Koopowitz H, Thornhill A (1994) Gene banking and orchid seeds. Am Orchid Soc Bull 63:1383-1386

Lahav E, Gottreich M (1984) The effect of growth hormones on bananas: a review. Plant Growth Regul 2:15-30. doi:10.1007/BF00024092

Lando AP, Wolfart MR, Fermino PCP Jr, Santos M (2016) Structural effects on Cattleya xanthina leaves cultivated in vitro and acclimatized ex vitro. Biol Plantarum 60(2):219225. doi:10.1007/s10535-016-0589-3

Li DZ, Pritchard HW (2009) The science and economics of ex situ plant conservation. Trends Plant Sci 14:614-621. doi:10.1016/j.tplants.2009.09.005

Lo SF, Nalawade SM, Kuo Chen CL, Tsay HS (2004) Asymbiotic germination of immature seeds, plantlet development and ex vitro establishment of plantlets of Dendrobium tosaense Makino - a medicinally important orchid. In Vitro Cell Dev Biol Plant 40:528535. doi:10.1079/IVP2004571

Lone AB, Assari Takahashi LS, de Faria RT, de Assis AM, Unemoto LK (2010) Vegetative development of orchids submitted to different macronutrient formulations and fertilization frequencies during the acclimatization phase. Semina: Ciênc Agrár Londrina 31(4):895-900. doi:10.5433/1679-0359.2010v31n4p895

Lurswijidjarus W, Thammasiri K (2004) Cryopreservation of shoot tips of Dendrobium Walter Oumae by encapsulation/dehydration. Sci Asia 30:293-299. doi:10.2306/scienceasia1513-1874.2004.30.293

Malmgren S (1996) Orchid propagation: theory and practice. In: Allen C (ed) North American native terrestrial orchids: propagation and production. North American Native Terrestrial Orchid Conference, Maryland, pp 63-71. doi:10.5962/bhl.title.131246

Marco DE, Páez SA (2000) Invasion of Gleditsia triacanthos in Lithraea ternifolia Montane Forests of Central Argentina. Environ Manage 26:409-419. doi:10.1007/s002670010098 
Martin KP, Pradeep AK (2003) Simple strategy for the in vitro conservation of Ipsea malabarica an endemic and endangered orchid of the Western Ghats of Kerala, India. Plant Cell Tissue Organ Cult 74:197-200. doi:10.1023/A:1023971625994

Massaro R, Cordeiro GM, De Souza-Leal T, Pedroso-de-Moraes C (2012) Desenvolvimento in vitro de Epidendrum secundum Jacq. em meios de cultivo simplificados. Rev Agro Amb 5(2):337-351

Medina RD, Flachsland EA, Gonzalez AM, Terada G, Faloci MM, Mroginski LA (2009) In vitro tuberization and plant regeneration from multinodal segment culture of Habenaria bractescens Lindl., an Argentinean wetland orchid. Plant Cell Tiss Organ Cult 97:91101. doi:10.1007/s11240-009-9505-2

Menezes LC (2000) Genus Cyrtopodium: espécies brasileiras. Editorial IBAMA, Brasilia

Merritt DJ, Hay FR, Swarts ND, Sommerville KD, Dixon KW (2014) Ex situ conservation and cryopreservation of orchid germplasm. Int J Plant Sci 175:46-58. doi:10.1086/673370

Mantovani C, Pivetta KFL (2016) In vitro development of Encyclea cordigera in different concentrations of honey. Ciênc Rural Santa Maria 46(4):590-592. doi:10.1590/0103$8478 \mathrm{cr} 20150046$

Mora F, de Menezes Gonçalves L, Scapim CA, Nunes Martins E, Pires da Silva Machado MF (2008) Generalized lineal models for the analysis of binary data from propagation experiments of Brazilian orchids. Braz Arch Biol Technol 51(5):963-970. doi:10.1590/S1516-89132008000500013

Morel G (1960) Producing virus-free cymbidiums. Am Orchid Soc Bull 29:495-497

Ministerio de Ambiente y Desarrollo Sostenible y Universidad Nacional de Colombia (2015) Plan para el estudio y la conservación de las orquídeas en Colombia. Ministerio de Ambiente y Desarrollo Sostenible; Universidad Nacional de Colombia, $336 \mathrm{p}$

Mitchell R (1989) Growing hardy orchids from seeds at Kew. Plantsman 11:152-169

Mitra GC (1971) Studies on seeds, shoot tips and stem disc of an orchid grown in aseptic culture. Indian J Exp Biol 9:79-85

Mitra GC, Prasad RN, Roychowdhary A (1976) Inorganic salts and differentiation of protocorms in seed-callus of an orchid and correlated changes in its free amino acid content. Indian J Exp Biol 14:350-351

Mitsukuri K, Mori G, Johkan M, Shimada Y, Mishiba KI, Morikawa T, Oda M (2009) Effects of explant position and dark treatment on bud formation in floret culture of Ponerorchis graminiflolia Rchb. f. Sci Hortic 121:243-247. doi:10.1016/j.scienta.2009.01.033

Monteiro do Rêgo M, Ramalho Do Rêgo E, Carvalho Dos Santos HC (2009) Micropropagation of an Amazonian terrestrial orchid (Brassia biddens) from Roraima State, Brazil. Acta Hort 813:459-464. doi:10.17660/ActaHortic.2009.813.60

Moraes L, Faria RT, Cuquel FL (2005) Activated charcoal for in vitro propagation of Brazilian orchids. Acta Hort 683:383-390. doi:10.17660/ActaHortic.2005.683.50

Murashige T, Skoog F (1962) A revised medium for rapid growth and bioassay with tobacco tissue cultures. Physiol Plant 15:473-497. doi:10.1111/j.1399-3054.1962.tb08052.x

Mweetwa AM, Welbaum GE, Tay D (2007) Orchid seed storage for germplasm preservation. Acta Hortic 760:629-635. doi:10.17660/ActaHortic.2007.760.89

Myers N, Mittermeier RA, Mittermeier CG, da Fonseca GAB, Kent J (2000) Biodiversity Hotspots for conservation priorities. Nature 403:853-858. doi:10.1038/35002501 
Na HY, Kondo K (1996) Cryopreservation of tissue-cultured shoot primordia from shoot apices of cultured protocorms in Vanda pumila following ABA preculture and desiccation. Plant Sci 118:195-201. doi:10.1016/0168-9452(96)04438-X

Nayak NR, Patnaik S, Rath SP (1997a) Direct shoot regeneration from foliar explants of an epiphytic orchid, Acampe praemorsa (Roxb.) Blatter \& McCain. Plant Cell Rep 16:583587. doi:10.1007/BF01142328

Nayak NR, Rath SP, Patnaik S (1997b) In vitro propagation of three epiphytic orchids, Cymbidium aloifolium (L.) Sw., Dendrobium aphyllum (Roxb.) Fisch. and Dendrobium moschatum (Buch.-Ham.) Sw. through thidiazuron-induced high frequency shoot proliferation. Sci Hortic 71:243-250. doi:10.1016/S0304-4238(97)00075-7

Nayak NR, Chand PK, Rath SP, Patnaik SN (1998) Influence of some plant growth regulators on the growth and organogenesis of Cymbidium aloifolium (L.) Sw. seed-derived rhizomes in vitro. In Vitro Cell Dev Biol Plant 34: 185-188. doi:10.1007/BF02822706

Nhut DT, Thi NN, Khiet BLT, LuanVQ (2008) Peptone stimulates in vitro shoot and root regeneration of avocado (Persea americana Mill). Sci Hortic 115:124-128. doi:10.1016/j.scienta.2007.08.011

Nikishina TV, Popov AS, Kolomeitseva GL, Golovkin BN (2001) Effect of cryoconservation on seed germination of rare tropical orchids. Fiziol Rast (Moscow) 48:930-936 (Russ J Plant Physiol, Engl Transl, pp 810-815)

Nikishina TV, Popova EV, Vakhrameeva MG, Varlygina TI, Kolomeitseva GL, Burov AV, Popovich EA, Shirokov AI, Shumilov VY, Popov AS (2007) Cryopreservation of seeds and protocorms of rare temperate orchids. Russ J Plant Physiol 54(1):121-127. doi:10.1134/S1021443707010189

Noguera-Savelli EJ, Carnevali F-C G, Romero-González GA (2008) Description of a new species and notes on Crossoglossa (Orchidaceae: Epidendroideae: Malaxideae) from the eastern Andes in Colombia and Venezuela. Britonia 60(3):240-244. doi:10.1007/s12228008-9020-5

Noguera-Savelli E, Cetzal-Ix W, Burguillos M, Tillett J, Jiménez E, Kumar Basu S (2015) The floristic composition and biodiversity of Orchidaceae in the Guatopo National Park, Venezuela and the urgent need for the conservation of the parks biodiversity. J Torrey Bot Soc 142(1):63-77. doi:10.3159/TORREY-D-14-00049.1

Oliva AP, Arditti J (1984) Seed germination of North American orchids. II. Native California and related species of Aplectrum, Cypripedium and Spirenthes. Bot Gaz 145:495-501. doi:10.1086/337484

Orejuela Gartner JE (2010) La conservación de orquídeas en Colombia y un caso en proceso en la cuenca del río Cali, municipio de Santiago de Cali, Valle del Cauca, Colombia. El Hombre y la Máquina 35: 53-66

Otero Ospina JT, Bayman P (2009) Germinación simbiótica y asimbiótica en semillas de orquídeas epífitas. Acta Agron 58:270-276

Pacini E, Hesse M (2002) Types of pollen dispersal units in orchids, and their consequences for germination and fertilization. Ann Bot 89:653-664. doi:10.1093/aob/mcf138

Paek KY, Murthy HN (1977) Temperate oriental Cymbidium species. In: Kull T, Arditti J (eds) Orchid biology: Reviews and perspectives, VIII. Kluwer Academic Publishers, 287 $\mathrm{p}$

Palama TL, Menard P, Fock I, Choi YH, Bourdon E, Govinden-Soulange J, Bahut M, Payet B, Verpoorte R, Kodja H (2010) Shoot differentiation from protocorm callus cultures of 
Vanilla planifolia (Orchidaceae): proteomic and metabolic responses at early stage. BMC Plant Biol 10:82. doi:10.1186/1471-2229-10-82

Panis B, Lambardi M (2005) Status of cryopreservation technologies in plants (crops and forest trees). In: Ruane J, Sonnino A (eds) The role of biotechnology in exploring and protecting agricultural genetic resources. FAO, Roma, pp 61-78

Park SY, Murthy HN, Paek KY (2003) Protocorm-like body induction and subsequent plant regeneration from root tip cultures of Doritaenopsis. Plant Sci 164:919-923. doi:10.1016/S0168-9452(03)00019-0

Pasqual M, Soares JDR, Rodrigues FA, Araujo AG, Santos RR (2011) Influência da qualidade de luz e silício no crescimento in vitro de orquídeas nativas e híbridas. Hortic Bras 29:324-329. doi:10.1590/S0102-05362011000300011

Paudel M, Pradhan S, Pant B (2012) In vitro seed germination and seedling development of Esmeralda clarkei Rchb.F. (Orchidaceae). Plant Tissue Cult Biotechnol 22(2):107-111. doi:10.3329/ptcb.v22i2.14197

Paul S, Kumaria S, Tandon P (2011) An effective nutrient medium for asymbiotic seed germination and large scale in vitro regeneration of Dendrobium hookerianum, a threatened orchid of Northeast India. AoB Plants 2011: plr032. doi:10.1093/aobpla/plr032

Pedroso-de-Moraes C, de Souza-Leal T, Panosso AR, Claro de Souza M (2012) Efeitos da escarificação química e da concentração de nitrogênio sobre a germinação e o desenvolvimento in vitro de Vanilla planifolia Jack ex Andr. (Orchidaceae: Vanilloideae). Acta Bot Bras 26(3):714-719. doi:10.1590/S0102-33062012000300022

Pedroza-Manrique J, Fernandez-Lizarazo C, Suarez-Silva A (2005) Evaluation of the effect of three growth regulators in the germination of Comparettia falcata seeds under in vitro conditions. In Vitro Cell Dev Biol Plant 41:838-843. doi:10.1079/IVP2005698

Pedroza-Manrique J, Mican-Gutiérrez Y (2006) Asymbiotic germination of Odontoglossum gloriosum RCHB.F (Orchidaceae) under in vitro conditions. In Vitro Cell Dev Biol Plant 42(6):543-547. doi:10.1079/IVP2006793

Pereira OL, Megumi Kasuya MC, Rollemberg C, Borges A (2005) In vitro symbiotic seed germination of Oncidium flexosum (Orchidaceae) by Rhizoctonia-like mycorrhizal fungi. R Bras Ci Solo 29:199-206. doi:10.1590/S0100-06832005000200005

Pereira G, Albornoz V, Muñoz-Tapia L, Romero C, Atala C (2015) Asymbiotic germination of Bipinnula fimbriata (Orchidaceae) seeds in different culture media. Seed Sci Technol 43:367-377. doi:10.15258/sst.2015.43.3.01

Pereira G, Albornoz V, Romero C, Lara S, Sánchez-Olate M, Ríos D, Atala C (2017) Asymbiotic germination in three Chloraea species (Orchidaceae) from Chile. Gayana Bot 74(1):131-139. doi:10.4067/S0717-66432017005000107

Pereira NS, Ferreira BRR, de Carvalho EM, Damiani CR (2018) Application of Chlorella sorokiniana (Chlorophyceae) as supplement and/or an alternative medium for the in vitro cultivation of Schomburgkia crispa (Orchidaceae). J Appl Phycol 30(4):2347-2358. doi:10.1007/s10811-018-1441-2

Pereira Gomes LR, do Rosário Batista Franceschi C, Lopes Fortes Ribas L (2015) Micropropagation of Brasilidium forbesii (Orchidaceae) through transverse and longitudinal thin cell layer culture. Acta Sci Biol Sci 37(2):143-149. doi:10.4025/actascibiolsci.v37i2.27276 
Peres LEP, Amar S, Kerbauy GB, Salatino A, Safari GR, Mercier H (1999) Effects of auxin, cytokinin and ethylene treatments on the endogenous ethylene and auxin-to-cytokinins ratio related to direct root tip conversion of Catasetum fimbriatum Lindl. (Orchidaceae) into buds. J Plant Physiol 155(4-5):551-555. doi:10.1016/S0176-1617(99)80053-4

Perú Ministerio del Ambiente (2015) Guía de identificación de orquídeas con mayor demanda comercial. Editora Image Print Peru EIRL, Lima, 99 p

Piri H, Pathak P, Bhanwra RK (2013) Asymbiotic germination of immature embryos of a medicinally important epiphytic orchid Acampe papillosa (Lindl.) Lindl. Afr J Biotech 12(2):162-167. doi:10.5897/AJB11.4001

Pizano C, García H (2014) El bosque seco tropical en Colombia. Instituto de Investigación de Recursos Biológicos Alexander von Humboldt (IAvH), Bogotá DC, $213 \mathrm{p}$

Popov AS, Popova EV, Nikishina TV, Kolomeytseva GL (2004) The development of juvenile plants of the hybrid orchid Bratonia after seed cryopreservation. CryoLett 25:205-212

Popova EV, Nikishina TV, Kolomeitseva GL, Popov AS (2003) The effect of seed cryopreservation on the development of protocorms by the hybrid orchid Bratonia. Russ J Plant Physiol 50:672-677

Popova E, Kim HH, Saxena PK, Engelmann F, Pritchard HW (2016) Frozen beauty: The cryobiotechnology of orchid diversity. Biotechnol Adv 34:380-403. doi:10.1016/j.biotechadv.2016.01.001

Pridgeon AM, Chase MW (1995) Subterranean axes in Tribe Diurideae (Orchidaceae): Morphology, anatomy, and systematic significance. Am J Bot 82:1473-1491. doi: $10.2307 / 2446176$

Pridgeon AM, Cribb PJ, Chase MW, Rasmussen FN (1999) Genera Orchidacearum. Vol 1. General introduction. Apostasioideae. Cypripedioideae. Oxford University Press, Oxford, $197 \mathrm{p}$

Pridgeon AM, Cribb PJ, Chase MW, Rasmussen FN (2001) Genera Orchidacearum. Vol 2. Orchidoideae (Part One). Oxford University Press, Oxford, $464 \mathrm{p}$

Pridgeon AM, Cribb PJ, Chase MW, Rasmussen FN (2003) Genera Orchidacearum. Vol 3. Orchidoideae (Part Two). Vanilloideae. Oxford University Press, Oxford, 360 p. doi: $10.2307 / 4111088$

Pritchard HW (1984) Liquid nitrogen preservation of terrestrial and epiphytic orchid seeds. CryoLett 5:295-300

Pritchard HW, Seaton PT (1993) Orchid seed storage: Historical perspective, current status, and future prospects for long-term conservation. Selbyana 14:89-104

Pritchard HW, Poynter LC, Seaton PT (1999) Interspecific variation in orchid seed longevity in relation to ultra-dry storage and cryopreservation. Lindleyeana 14:92-101

Pritchard HW, Dickie JB (2003) Predicting seed longevity: use and abuse of seed viability equations. In: Smith RD, Dickie JB, Linington SH, Pritchard HW, Probert RJ (eds) Seed conservation: turning science into practice. Royal Botanic Gardens Kew, pp 653-722

Prizão EC, de Menezes Gonçalves L, Milaneze Gutierre MA, Mangolin CA, Pires da Silva Machado MF (2012) Activated charcoal and graphite for the micropropagation of Cattleya bicolor Lindl. and a orchid double-hybrid 'BLC Pastoral Innocence'. Acta Sci Agron 34(2):157-161. doi:10.4025/actasciagron.v34i2.12257

Quiroz K, Saavedra J, Vogel H, Verdugo G, Caligari PDS, García-Gonzáles R (2017) In Vitro asymbiotic germination for micropropagation of the recalcitrant terrestrial orchid Chloraea crispa (Orchidaceae). Appl Plant Sci 5(8):1600142. doi:10.3732/apps. 1600142 
Ramírez-Mosqueda MA, Iglesias-Andreu LG (2015) Indirect organogenesis and assessment of somaclonal variation in plantlets of Vanilla planifolia Jacks. Plant Cell Tiss Organ Cult 123:657-664. doi:10.1007/s11240-015-0868-2

Rangsayatorn N, Jina K, Pampasit S (2009) Slow growth in vitro conservation of Dendrobium draconis Rchb. f.: effect of black Kwao Krua (Mucuna collettii Lace). Acta Hortic 829:355-358. doi:10.17660/ActaHortic.2009.829.56

Rasmussen HN, Dixon KW, Jersakova J, Tesitelova T (2015) Germination and seedling establishment in orchids: A complex of requirements. Ann Bot 116:391-402. doi:10.1093/aob/mcv087

Roberts MCL, Alvarado GV, Sánchez BM, Franco JB, Llanos MA, Portugal JQ (2007) Orchids' micropropagation for to the sustainable management of native species from Parque Nacional y área Natural de Manejo Integrado Cotapata (PN-ANMI Cotapata), La Paz-Bolivia. Lankesteriana 7(1-2):299-302. doi:10.15517/lank.v7i1-2.19524

Rodrigues DT, Ferreira Novais R, Alvarez Venegas VH, Moreira Dias JM, Campos Otoni W, Albuquerque Villani EM (2013) Chemical sterilization in in vitro propagation of Arundina bambusifolia Lindl. and Epidendrum ibaguense Kunth. Rev Ceres Viçosa 60(4):447-451. doi:10.1590/S0034-737X2013000400001

Rodrigues LA, Borges de Paiva Neto V, Galdi Boaretto A, Fernanda de Oliveira J, de Aguiar Torrezan M, Ferreira de Lima S, Campos Otoni W (2015) In vitro propagation of Cyrtopodium saintlegerianum Rchb. f. (Orchidaceae), a native orchid of the Brazilian savannah. Crop Breed Appl Biotechnol 15(1):10-17. doi:10.1590/1984$70332015 v 15 n 1 \mathrm{a} 2$

Rodrigues Guimarães FA, Corrêa Pereira M, da Silva Felício C, Pereira Torres D, Oliveira SF, Gomes Reis Veloso T, Megumi Kasuya MC (2013) Symbiotic propagation of seedlings of Cyrtopodium glutiniferum Raddi (Orchidaceae). Acta Bot Bras 27(3):590596. doi:10.1590/S0102-33062013000300016

Romero C, Cuba-Díaz M, Silva R (2018) In vitro culture of Chloraea gavilu Lindl., an endemic terrestrial orchid from Chile. Plant Biosys 152(4):612-620. doi:10.1080/11263504.2017.1306001

Roque J, León B (2006) Orchidaceae endémicas del Perú. Rev Peru Biol 13(2):759-878. doi:10.15381/rpb.v13i2.1953

Roy AR, Patel RS, Patel VV, Sajeev S, Deka BC (2011) Asymbiotic seed germination, mass propagation and seedling development of Vanda coerulea Griff ex. Lindl. (Blue Vanda): an in vitro protocol for an endangered orchid. Sci Hortic 128:325-331. doi:10.1016/j.scienta.2011.01.023

Sakai A, Kobayashi S, Oiyama I (1990) Cryopreservation of nucellar cells of naval orange (Citrus sinensis var. brasiliensis Tanaka) by vitrification. Plant Cell Rep 9:30-33. doi:10.1007/BF00232130

Sánchez MI (1986) Novedades en Cyrtopodium (Orchidaceae) para la Argentina. Parodiana 4(1):63-71

Sánchez MI (1988) Micropropagation of Cyrtopodium (Orchidaceae) through root-tip culture. Lindleyana 3:93-96

Sánchez MI, Valebella M (2012) Novedades en Cyrtopodium para la Argentina. Bonplandia 21(2):139-147

Santana GE, Chaparro K (1999) Clonal propagation of Oncidium through the culture of floral buds. Acta Hortic 482: 315-320. doi:10.17660/ActaHortic.1999.482.46 
Sasamori MH, Endres Júnior D, Droste A (2015) Asymbiotic culture of Cattleya intermedia Graham (Orchidaceae): the influence of macronutrient salts and sucrose concentrations on survival and development of plantlets. Acta Bot Bras 29(3):292-298. doi:10.1590/0102-33062014abb0054

Schinini A, Waechter J, Isaguirre P, Lehnebach C (2008). Ochidaceae. In: Zuloaga F, Morrone O, Belgrano M (eds) Catálogo de las plantas vasculares del Cono Sur. Vol. 1. Missouri Botanical Garden, pp 472-608

Schnitzer JA, Tadeu de Faria R, Ursi Ventura M, Sorace M (2010) Substratos e extrato pirolenhoso no cultivo de orquídeas brasileiras Cattleya intermedia (John Lindley) e Miltonia clowesii (John Lindley) (Orchidaceae). Acta Sci Agron 32(1):139-143. doi:10.4025/actasciagron.v32i1.714

Seaton PT, Hu H, Perner H, Pritchard HW (2010) Ex situ conservation of orchids in a warming world. The Bot Rev 76:193-203. doi:10.1007/s12229-010-9048-6

Seaton P, Kendon JP, Pritchard HW, Puspitaningtyas DM, Marks TR (2013) Orchid conservation: the next ten years. Lankestriana 13:93-101. doi:10.15517/LANK.V0I0.11545

Seeni S, Latha PG (2000) In vitro multiplication and ecorehabilitation of the endangerd Blue Vanda. Plant Cell Tissue Org Cult 61:1-8. doi:10.1023/A:1006444614657

Sérsic A, Cocucci A, Benítez-Vieyra S, Cosacov A Díaz L, Glinos E, Grosso N, Lazarte C, Medina M, Moré M, Moyano M, Nattero J, Paiaro V, Trujillo C, Wiemer P (2006) Flores del centro de Argentina. Academia Nacional de Ciencias, Córdoba, 354 pp

Shands H (1991) Complementarity of in situ and ex situ germplasm conservation from the standpoint for the future user. Israeli J Bot 40:521-528

Sharma A, Tandon P (1992) In vitro culture of D. wardianum Warner: morphogenetic effects of some heterogenous adjuvants. Indian J Plant Physiol 35:80-85

Sharma V, Vij SP (1997) Effect of $\mathrm{CuSO}_{4}, 5 \mathrm{H}_{2} \mathrm{O}$ on in vitro regenerative capacity of foliar explants excised from mature Vanda cristata Lindl. plants. Phytomorphology 47:203208

Sheela VL, Rajmohan K, Anita S, Sarada S (2004) Effect of growth regulators on development and multiplication of protocorm like bodies in Dendrobium cv Sonia. J Orchid Soc India 18:21-23

Shi YZ, Pan RC, Wang XJ, Ye QS, Guo LR (2000) In vitro conservation of Dendrobium officinale at low temperature. Chin J App Environ Biol 6:326-330

Shimasaki K, Uemoto S (1990) Micropropagation of a terrestrial Cymbidium species using rhizomes developed from seeds and pseudobulbs. Plant Cell Tissue Org Cult 22:237-244. doi:10.1007/BF00033642

Shimasaki K, Uemoto S (1991) Rhizome induction and plantlet regeneration of Cymbidium goeringii from flower bud cultures in vitro. Plant Cell Tissue Org Cult 25:49-52. doi:10.1007/BF00033912

Sobral A, Fracchia S (2010) Aa achalensis Schltr (Orchidaceae) en la Sierra de Velasco, La Rioja, Argentina. Kurtziana 35:19-21

Sorace M, Tadeu de Faria R, Damasceno Júnior CV, Gomes GP, Muniz Barbosa C, Nesello Vieira FG, Lopes da Silva G, Sadayo Assari Takahashi L, Schnitzer JÁ (2008) In vitro growth of Oncidium baueri (Orchidaceae) at different macronutrients and sucrose concentrations. Semina: Ciênc Agrár Londrina 29(4):775-782. doi:10.5433/16790359.2008v29n4p775 
Speranza A, Calzoni GL, Pacini E (1997) Occurrence of mono- or disaccharides and polysaccharide reserves in mature pollen grains. Sex Plant Reprod 10:110-115. doi:10.1007/s004970050076

Stancato GC, Abreu MF, Furlani AMC (2008) The pulps of fruits in the growth of epiphytic orchids. Bragantia 67(1):51-57. doi:10.1590/S0006-87052008000100006

Steinfort U, Verdugo G, Besoain X, Cisternas MA (2010) Mycorrhizal association and symbiotic germination of the terrestrial orchid Bipinnula fimbriata (Poepp.) Johnst (Orchidaceae). Flora 205(12):811-817. doi:10.1016/j.flora.2010.01.005

Steward FC, Simmonds NW (1954) Growth-promoting substances in the ovary and immature fruit of banana. Nature 173:1083-1084

Surenciski MR, Dematteis M, Flachsland EA (2007) Chromosome stability in cryopreserved germplasm of Cyrtopodium hatschbachii (Orchidaceae). Ann Bot Fennici 44:287-292

Surenciski MR, Flachsland EA, Terada G, Mroginski LA, Rey HY (2012) Cryopreservation of Cyrtopodium hatschbachii Pabst (Orchidaceae) immature seeds by encapsulationdehydration. Biocell 36(1): 31-36

Suzuki RM, Moreira VC, Pescador R, de Melo Ferreira W (2012) Asymbiotic seed germination and in vitro seedling development of the threatened orchid Hoffmannseggella cinnabarina. In Vitro Cell Dev Biol Plant 48(5):500-511. doi:10.1007/s11627-012-9460-1

Suzuki ABP, Morais Vidal TC, Cito Alves GA, Bertoncelli Junior D, Biz G, Sorace M, Tadeu de Faria R (2018) Cryopreservation of Brazilian orchid (Catasetum atratum Lindl.) seed at risk of extinction. Aust J Crop Sci 12(07):1051-1057. doi:10.21475/ajcs.18.12.07.PNE809

Swarts ND, Dixon KW (2009) Perspectives on orchid conservation in botanic gardens. Trends Plant Sci 14:11. doi:10.1016/j.tplants.2009.07.008

Teng WL, Nicholson L, Teng MC (1997) Micropropagation of Spathoglottis plicata. Plant Cell Rep 16:831-835. doi:10.1007/s002990050329

Teixeira da Silva JA, Zeng S, Galdiano Júnior RF, Dobránszki J, Cardoso JC, Vendrame WA (2014) In vitro conservation of Dendrobium germplasm. Plant Cell Rep 33:1413-1423. doi:10.1007/s00299-014-1631-6

Thakur U, Dongarwar N (2013) A new report of in vitro flowering and multiple shooting in a wild epiphytic orchid Oberonia recurva Lindl. from asymbiotically germinated seedling. Plant Knowledge Journal 2(3):113-118

Thinh NT, Takagi H (2000) Cryopreservation of in vitro-grown apical meristems of terrestrial orchids (Cymbidium spp.) by vitrification. In: Engelmann F, Takagi H (eds) Cryopreservation of Tropical Plant Germplasm Current Research Progress and Application. JIRCAS, IPGRI, Rome, pp 453-455

Tikhonova VL, Lysykh NI, Firsanova VM (1997) The effect of freezing on the viability of wild plant seeds. Byulleten' Glavnogo Botaniceskogo Sada 175:83-90

Tokuhara K, Mii M (1998) Somaclonal variations in flower and inflorescence axis in micropropagated plants through flower stalk bud culture of Phalaenopsis and Doritaenopsis. Plant Biotechnol 1:23-28. doi:10.5511/plantbiotechnology.15.23

Torres A J, Sanabria CH ME (2011) Efecto del ambiente de desarrollo sobre la anatomía foliar de Cattleya jenmanii Rolfe y C. lueddemanniana Rchb.f. (Orchidaceae) Acta Bot Venez 34(1):199-214 
Torretta JP, Gomiz NE, Aliscioni SS, Bello ME (2011) Biología reproductiva de Gomesa bifolia (Orchidaceae, Cymbidieae, Oncidiinae). Darwiniana 49(1):16-24

Tressens SG, Arbo MM (2002). Introduction. In: Arbo MM, Tressens SG (eds) Flora del Iberá. EUDENE, Corrientes, pp 3-7

Tsukazaki H, Mii M, Tokuhara K, Ishikawa K (2000) Cryopreservation of Doritaenopsis suspension culture by vitrification. Plant Cell Rep 19:1160-1164. doi:10.1007/s002990000255

Uragami A (1993) Cryopreservation of cultured cells and organs of vegetables. In: Cryopreservation of plant genetic resources. Technical Assistance Activities for Genetic Resources Projects Nº 6. JICA, Japan, pp 111-131

Vacin EF, Went FW (1949) Some pH changes in nutrient solutions. Bot Gaz 110:605-13

Valadares RB, Pereira MC, Otero JT, Cardoso EJ (2012) Narrow fungal mycorrhzal diversity in a population of the orchid Coppensia doniana. Biotropica 44(1):114-122. doi:10.1111/j.1744-7429.2011.00769.x

Vale A, Pérez-Obregón RA, Faife-Cabrera M, Álvarez JC, Rojas D (2014) A new orchid species from the keys of central Cuba and a checklist of Cuban Encyclia (Orchidaceae, Laeliinae). System Bot 39:1076-82. doi:10.1600/036364414X684380

Valebella M (2017) Gomesa discifera (Orchidaceae), nueva cita para la flora de Argentina. Bonplandia 26(1):35-40

van den Berg C (2005) 293. Cattleya. In: Pridgeon AM, Cribb PJ, Chase MW, Rasmussen FN (eds) Genera orchidacearum, 4. Epidendroideae (Part One). Oxford University Press, Oxford, pp 213-217

van den Berg C (2008) New combinations in the genus Cattleya (Orchidaceae). Neodiversity 3:3-12. doi:10.13102/neod.51.4

van den Berg C (2014) Reaching a compromise between conflicting nuclear and plastid phylogenetic trees: a new classification for the genus Cattleya (Epidendreae; Epidendroideae; Orchidaceae). Phytotaxa 186(2):075-086. doi:10.11646/phytotaxa.186.2.2

van den Berg C, Martins PS (1998) Biogeography of Brazilian Cattleyas: geographic distribution, morphological variability, evolutionary and taxonomic consequences. In: Proceedings of the 15th World Orchid Conference, Rio de Janeiro, 1996. Naturalia Publications, Turriers, pp 315-320

van den Berg C, Higgins WE, Dressler RL, Whitten WM, Soto-Arenas MA, Culham A, Chase MW (2000) A phylogenetic analysis of Laeliinae (Orchidaceae) based on sequence data from internal transcribed spacers (ITS) of nuclear ribosomal DNA. Lindleyana 15:96-114

van den Berg C, Higgins WE, Dressler RL, Whitten WM, Soto-Arenas MA, Chase MW (2009) A phylogenetic study of Laeliinae (Orchidaceae) based on combined nuclear and plastid DNA sequences. Ann Bot 104:417-430. doi:10.1093/aob/mcp101

Van Waes JM, Debergh PC (1986) In vitro germination of some Western European orchids. Physiol Plant 67:253-261. doi:10.1111/j.1399-3054.1986.tb02452.x

Vásquez R, Ibisch PL, Gerkmann B (2003) Diversity of Bolivian Orchidaceae - a challenge for taxonomic, floristic and conservation research. Org Divers Evol 3:93-102. doi:10.1078/1439-6092-00061 
Vendrame WA, Maguire I, Carvalho VS (2007a) In vitro propagation and plantlet regeneration from Doritaenopsis Purple Gem 'Ching Hua' flower explants. HortScience 42(5):1256-1258

Vendrame WA, Carvalho VS, Dias JMM (2007b) In vitro germination and seedling development of cryopreserved Dendrobium hybrid mature seeds. Sci Hortic 114:188193. doi:10.1016/j.scienta.2007.06.006

Vendrame WA, Carvalho VS, Dias JMM, Maduir I (2008) Pollination of Dendrobium hybrids using cryopreserved pollen. HortScience 43:264-267

Vertucci CW, Roos EE (1993) Theoretical basis of protocols for seed storage. II. The influence of temperature on optimal moisture levels. Seed Sci Res 3:201-213. doi:10.1017/S0960258500001793

Vij SP, Kaur P (1999) Rapid clonal multiplication of Ascocenda 50th State Beauty through in vitro culture of leaf explants. Proc Natl Acad Sci India 69:317-321

Vijayakumar S, Rajalkshmi G, Kalimuthu K (2012) Propagation of Dendrobium aggregatum through the culture of immature seeds from green capsules. Lankesteriana 12(2):131135. doi:10.15517/LANK.V0I0.11763

Villa F, Pasqual M, Fernandes da Silva E (2014) Micropropagação de híbridos de orquídea em meio Knudson com adição de vitaminas do meio MS, benzilaminopurina e carvão ativado. Semina: Ciênc Agrár Londrina 35(2):683-694. doi:10.5433/16790359.2014v35n2p683

Vischi N, Natale E, Villamil C (2004) Six endemic plant species from central Argentina: an evaluation of their conservation status. Biodivers Conserv 13:997-1008

Vogel IN, Macedo AF (2011) Influence of IAA, TDZ, and light quality on asymbiotic germination, protocorm formation, and plantlet development of Cyrtopodium glutiniferum Raddi., a medicinal orchid. Plant Cell Tiss Organ Cult 104(2):147-155. doi:10.1007/s11240-010-9810-9

Vudala SM, Ribas LLF (2017) Seed storage and asymbiotic germination of Hadrolaelia grandis (Orchidaceae). S Afr J Bot 108:1-7. doi:10.1016/j.sajb.2016.09.008

Vyas S, Guha S, Bhattacharya M, Rao IU (2009) Rapid regeneration of plants of Dendrobium lituiflorum Lindl. (Orchidaceae) by using banana extract. Sci Hortic 121:32-37. doi:10.1016/j.scienta.2009.01.012

White TJ, Bruns T, Lee S, Taylor J (1990) Amplification and direct sequencing of fungal ribosomal RNA genes for phylogenetics. In: Innis MA, Gelfand DH, Sninsky JJ, White TJ (eds) PCR protocols: a guide to methods and applications. Academic Press, New York, pp 315-322

Wida Utami ES, Hariyanto S, Wulan Manuhara YS (2017) In vitro propagation of the endangered medicinal orchid, Dendrobium lasianthera J.J.Sm through mature seed culture. Asian Pac J Trop Biomed 7(5):406-410. doi:10.1016/j.apjtb.2017.01.011

Wood JJ (1989) British orchids in their European context. In: Pritchard HW (ed) Modern methods in orchid conservation: the role of physiology, ecology and management. Cambridge University Press, pp 141-145. doi:10.1017/CBO9780511551307

Yam TM, Weatherhead MA (1988) Germination and seedling development of some Hong Kong orchids. Lindeyana 3(3):156-160

Yam TM, Arditi J, Weatherhead MA (1989) The use of darkening agents in seed germination and tissue culture media for orchids: a review. J Orchid Soc India 3(1-2):35-39 
Zappi DC, Ranzato Filardi FL, Leitman P, Souza VC, Walter BMT, Pirani JR, Morim MP, Queiroz LP, Cavalcanti TB, Mansano VF, Forzza RC (2015) Growing knowledge: an overview of seed plant diversity in Brazil. Rodriguésia 66(4):1085-1113. doi:10.1590/2175-7860201566411

Zuloaga FO, Morrone O, Rodriguez D (1999) Análisis de la biodiversidad en plantas vasculares de la Argentina. Kurtziana 27(1):17-168

Zuloaga FO, Belgrano MJ (2015) The catalogue of vascular plants of the Southern Cone and the flora of Argentina: their contribution to the World Flora. Rodriguésia 66(4):9891024. doi:10.1590/2175-7860201566405 